Pauli RAHKONEN (Lahti)

\title{
Finno-Ugrian hydronyms of the River Volkhov and Luga catchment areas
}

\begin{abstract}
The aim of the present work is to study by the means of onomastics the language of the ancient Chudes mentioned by Russian chroniclers. More precisely, the research concerns the Chudes that inhabited the Novgorod Land before their assimilation with Slavs. The previous view has been that the language belonged to the Finnic group. In this work, I have defined the boundaries of actual Finnic toponyms, examined the areal connection of the formants of hydronyms, the distribution of Chud toponyms and the names of large bodies of waters in the Pskov territory between Estonia and Novgorod. The results of onomastics are also compared with archaeological data. The basic conclusion is that the language of these Chudes was not Finnic.
\end{abstract}

\section{Preface}

This study primarily examines the hydronyms of the River Volkhov and Luga catchment areas in order to trace the ethnohistory of the region over the approximate period 400-1100 AD. In addition, hydronyms of the River Syas and Narva catchment areas have been examined to some extent. I have ruled out the later Slavic toponyms and concentrated on the material assumed to be Finno-Ugrian.

This work is part of a series of articles intended as my doctoral thesis. The first article, "The Linguistic Background of the Ancient Meshchera Tribe and Principal Areas of Settlement" was published in Finnisch-Ugrische Forschungen 60 (2009). In this article, the boundaries of the ancient settlements of the Meshchera tribe and their linguistic background was determined. My dissertation has the title The South-Eastern Contact Field of the Finnic Languages. Its goal is primarily to describe the linguistic relations of the Finnic and hitherto unknown, extinct Finno-Ugrian languages of the Upper Volga and Oka area and place them within the Uralic linguistic family. ${ }^{1}$ Furthermore, I attempt to trace as far as possible the languages and settlements of the vanished and poorly researched Finno-Ugrian tribes of the Upper Volkhov and Luga area.

In the present article I concentrate on the linguistic connections between the Finnic populations and the Novgorodian Chudes mentioned frequently in the Russian chronicles. In Section 2, I present the topic of investigation and its history. Section 3 , which deals with research methods, is rather long because the substrate toponyms are based on a language (or languages) now extinct, making the research more com-

1 Finnic is the linguistic group consisting of Livonian, Estonian, Vote, Finnish, Karelian, Olonetsian, Lude and Veps. Finno-Ugrian refers to the Uralic languages with the exception of Samoyed, although this definition may not reflect the real history of the language family. Because I have followed Sammallahti's reconstructions of the Uralic proto-languages (1988) I have followed his terminology as well. 
plicated. In Section 4 the research work consists of the transparently Finnic or otherwise possible Finnic hydronyms in Leningrad and Novgorod oblasts. In Section 5, I analyse the (topo)formants of the Finno-Ugrian hydronyms in Novgorod oblast. In Section 6, I examine the sounds $\langle\breve{c}>$ and $\langle\breve{s}>$ alien to Finnic languages, as well as Finno-Ugrian hydronyms in the research field displaying an initial $\langle h\rangle$ typical for Finnic. ${ }^{2}$ In Section 7 I examine the ethnonyms. Finally, in Section 8 I, to some extent, examine the hydronyms of the Pskov area. The Pskov region is located between Southern Estonia and Novgorod. If Novgorodian Chudes can be connected with the southern Estonians, this should be visible in the toponyms of the Pskov region. My conclusions are presented in Section 9.

In my transcription of the toponyms, Russian names and words written in Cyrillic, I follow the definitions of the U.S. Board on Geographic Names (BGN) and the Permanent Committee on Geographic Names for British Official Use (PCGN) with the exception of such expressions whose spellings are widely in general use, e.g. Moscow. However, in some cases the Russian $b$ is marked with an apostrophe, if linguistic reasons demand it.

\section{Research questions and research history}

It is assumed that the enormous area between the Upper Volga and Lake Peipus was populated by Finno-Ugrian peoples until their russification in the Late Middle Ages. However, little attention has been given to the question of what languages were spoken in the area. Ethnohistorical debate has mainly been carried out by archaeologists. For this reason, there has been no deep linguistic analysis. Usually the research has been based only on the names of large bodies of water considered to be Finno-Ugrian, such as the lakes oz. Ilmen < *Imeŕ, oz. Seliger < *Seriger and the river Msta (e.g. Isakov 1985: 17; Uino 2006: 359; Mullonen 2002; 232-233). Sedov has defined the southern boundaries of Finno-Ugrian toponyms as running alongside the northern side of the river Daugava ( $\sim$ Zapadnaya Dvina) from Livonia to the Kaluga region (Ryabinin 1997: 4, Fig. 1 according to Sedov; see Map 2).

Although not only Sedov, but also such scholars as Popov (1981) and Vasilyev (2005: 19) and others have noted the Finno-Ugrian layer of toponyms, I have not heard of any more precise analysis that would define to which Finno-Ugrian linguistic group the toponyms should belong. Russian scholars are understandably interested primarily in Slavic migrations, slavicization and the toponyms connected with these. Vasilyev (2005) has written quite widely on ancient Slavic toponyms. Important Russian publications include Popov's Iz istorii finno-ugorskikh narodnostey SSSR (1947), Sedov's article "Etnicheskiy sostav naseleniya Novgorodskoy zemli" in the book FinnoUgry i Slavyane (1979), Tretyakov's Finno-Ugry, Balty i Slavyane na Dnepre i Volge (1966) and Ageyeva's Gidronimiya Russkogo Severo-Zapada kak istochnik kulturno-

2 For example, in the Karelian branch of Finnic the sound $\check{s}$ exists, but it is secondary $\left({ }^{*} S>\check{s}\right)$. 
istoricheskoy informatsii (1989). In Finnish circles, no thorough study of Finno-Ugrian substrate toponyms in the area has been performed until now. There has existed a general assumption that the Chudes belonged to the Finnic linguistic group and lived east of Lake Peipus on the upper reaches of the rivers Luga and Volkhov, mostly in the area of modern Novgorod oblast. This idea is based on ancient Russian chronicles and interpretations of archaeological data (Grünthal 1997: 150-171 and attached literature).

In this study I have, utilizing the discipline of onomastics, endeavoured especially to trace the more exact linguistic background of the Finno-Ugrian population that named the bodies of waters in this area. I thus shall debate whether the toponyms confirm a Finnic origin for the Novgorodian Chudes as claimed in earlier literature, or if they do not, which geographical direction the lexical and structural content of the toponyms refers to. As I have already emphasized, the claim that the Chudes were a Finnic tribe has been based practically upon only the three hydronyms Ilmen, Seliger and Msta. From the point of view of archaeology, the claim has been supported by the assumption that the ethnic background of the Long Barrow Culture was Finnic.

\section{I. Chudes in the research frame}

Previous ethnohistorical research on the Novgorodian Land has concentrated especially on the Chudes mentioned in the ancient Russian chronicles. ${ }^{3}$ Riho Grünthal (1997: 151, 161) has argued that the ethnonym Chud(e) spread from the original Novgorodian area towards the north. He remarks that the essential problem in tracking down the origin of the Chudes is the poor knowledge of the ethnic history of the area around the lakes Chudskoye ozero $\sim$ Peipus and Ilmen. No doubt, these are noteworthy points when solving the problem. The portion concerning the Chudes in Grünthal's book is an extraordinary summary of the research published up to the time he wrote it.

Ryabinin, in turn, writes of the contacts between the Chudes and Slavs, looking at the question from a remarkably wider geographical perspective. Ryabinin (1997: 9-15) principally represents the Russian scientific discussion of the 20th century. His conclusion is that almost all of the Finno-Ugrian nations that the Slavs encountered when moving northwards were ultimately called Chudes (ibid. 1997: 9, footnote). Janne Saarikivi has reported of traditions in the River Pinega region in Arkhangelsk oblast and claims the present population to be partly descendants of the Chudes. There exist people who even today consider themselves to be Chudes (Saarikivi, personal information). Supposedly, in that area they may be the descendants of the so-called "Chudes behind the neck of land" [Russian заволочкие чуди], though the chronicles distinguish these from other Chudes (Lihatshov 1994: 10; PSRL 1965). Several Finnic tribes have been suggested to be the Chudes: Vote (Jaakkola 1935; Mägiste

3 There are numerous mentions of the Chudes also in the folklore of different districts and ethnic groups. Due to a lack of space, I have not broached this subject in the present article. 
1954; Itkonen 1961), Veps (Bubrikh 1947), Estonians (Ariste 1962) or some unknown Finnic group (Moora 1956). Some support can be found for each of these explanations. Therefore, in this study I have used the term "Novgorodian Chudes" in order to specify precisely those Chudes who lived mainly in the upper reaches of the River Volkhov and Luga catchment area and were mentioned in the early chronicles.

\subsection{Finnic anthroponyms of the Novgorodian Birchbark Documents}

According to Saarikivi (2007: 243-244), the Finnic anthroponyms of the Novgorodian Birchbark Documents mainly resemble the medieval names in the Karelian Isthmus and Ingria. It is important to note that the anthroponyms of these birchbark documents have almost no connection with Estonian names. If the Chudes really were linguistically linked with the Estonians, some similarity would be expected. It is also noteworthy that in the oldest stratum of the documents (ca 1000-1125 AD), no Finnic anthroponyms are found at all (ibid. 2007: 241). This stratum, however, is numerically small, but it may still give a hint that the Novgorodian Chudes were not necessarily a Finnic tribe. The argument presented by Grünthal (1997: 154), that the oldest Novgorodian administrative language does not mention either the Land of the Chudes or the Chudes as a nation, is most natural if the territory of Novgorod itself was the "Land of the Chudes". One must bear in mind that in the birchbark documents, the ethnonym in question is frequently represented (Janne Saarikivi, personal information).

\subsection{Archaeology of Novgorod, Leningrad and Pskov oblasts}

Archaeologists have also studied the Finno-Ugrian ethnohistory of the area to some extent. Uino and Yushkova have written of the so-called Volkhov Culture (ca 700$400 \mathrm{BC}$ ). The population of this culture has been understood as a group that spoke Proto-Finnic (Yushkova 2006: 140-141; Uino 2006: 362). Ryabinin, in turn, has tried to determine the boundaries of the ancient Vote and Ingrian settlements during the Medieval Ages (Ryabinin 1997: 4, Fig. 1 and 62, Fig. 18). The border of their settlement area has followed a line from the Lower Luga to the River Tigoda. The northern boundary of the Long Barrow Culture is located slightly south of it. The southern boundary of transparently Finnic hydronyms (see Section 4) is also placed rather close to these lines. (See Map 1.)

When studying the history of the Chudes by utilizing archaeological methods, there exists a fundamental disagreement: what possibilities does archaeology, as a scientific discipline, have to examine linguistic groups? ${ }^{4}$ This question has produced

4 It is not possible to treat such a wide and controversial subject in greater detail here. I shall only state that any language and certain features of a local material culture together usually form ethnic identities. The research challenge of archaeology is its ability to define as reliably as possible what kind of archaeological material really can serve as an ethnic marker. Such material can supposedly be found. 
several schools of thought. For example, Andres Tvauri (2007) has maintained a critical attitude towards combining archaeological data with linguistic or ethnic groups. A problem remains, however. What should the geographical area and the timeframe of the study be? Given that the earliest references to the Chudes of the chronicles are connected with the Pskov and Novgorod regions, it seems reasonable to start from there. The best starting point of the timeframe might be the earliest contacts between the Slavs and the Finnic tribes or the Chudes. These supposedly occurred around 400 AD (Kallio 2006: 157). After 1050 AD the chronicles cease to mention the Chudes. It is possible that the reason for no further mention of the Chudes after this date was a change in the structure of the Russian state itself. Russia changed from a federal union of various tribes to a coherent, Christian state and the whole population was simply called Russians.

\subsection{The Long Barrow Culture}

There has been heavy disagreement about the ethnic background of the so-called long barrows (kurgans) and sopka graves. ${ }^{5}$ The former are found in the Pskov-NovgorodSmolensk-River Mologa area (Tvauri 2007 and attached literature; see Map 2). The earliest findings (5th century AD) have been excavated especially in the Pskov region (Tvauri 2007: 253). Very early material of the Long Barrow Culture (5th century AD) is also found in the River Mologa area, in the Upper Volga as reported by Yushkova (2006: 145). Long barrows have also been found in Smolensk region in the Upper Dnieper, in the Polotsk area in the Upper Daugava and in East Latvia (Tvauri 2007: 261, 247). Laul (1973: 101) has linked the Pskovian long barrows with the Chudes he thought to be Finnic. In early Russian research, this culture was thought to be connected with the migration of the Slavic Kriviches (Chernyagin 1941; Tretyakov 1953; Tarakanova 1950; Sedov 1960).

Some researchers have been prepared to connect the origin of the Long Barrow Culture with Baltic tribes (Lyapushkin 1966: 130-131; 1968: 20-22; Spitsyn 1903; Gote 1930; see also Yushkova 2006: 146 and attached literature). The Long Barrow Culture seemingly spread to the Polotsk and Smolensk regions and further to the River Mologa via the River Daugava. Balts lived east of their present areas as far as the Moscow region at least as late as the 11th century AD. The Primary Chronicle, or Povest vremennykh let [PVL] tells of a tribe called Golyad [ East Galindies] (Lihatshov 1994: 105). Kriiska and Tvauri (2007: 148) present a map where, in their opinion, the area of the Balts reached the town of Kaluga on the River Oka (Map 4) during the Age of Migrations ( 5 th-7th centuries AD). The boundary between the Balts and the Finno-Ugrians runs in their map accordingly with the above-mentioned presentation of Sedov. The Baltic area also included the environs of Polotsk and Smolensk, towns which were founded later. Long barrows are found in these particular areas.

5 The question of the sopka graves is so controversial that there is no possibility to treat this subject in this article. 
The only Baltic tribe that lived on the northern side of the River Daugava were the Latgalians. Kriiska and Tvauri (2007: 193) report that after the Age of Migrations (5th-6th centuries AD) they settled down in ancient Finno-Ugrian land and preserved much of Livonian and South Estonian culture among themselves. Machinskiy regards the Long Barrow Culture as originating from Baltic tribes. According to him, the area later became Finnic (Machinskiy 1990: 116-119). Slavs undoubtedly began to move to the area of the Long Barrow Culture in the beginning of the second half of the first millennium at the latest.

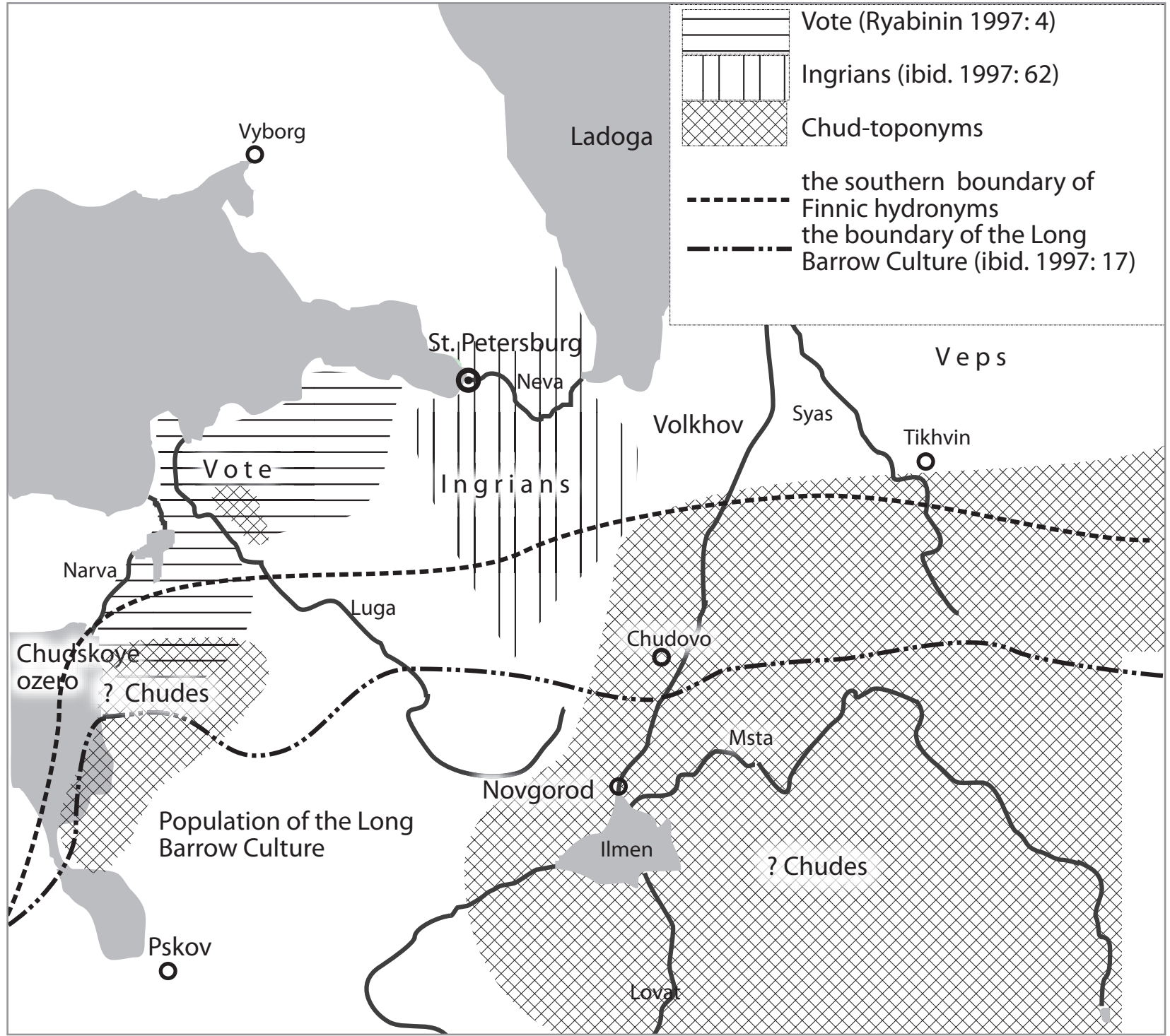

Map I.The medieval ethnographic situation of Finno-Ugrian tribes in Leningrad, Pskov and Novgorod oblasts (featuring Ryabinin 1997: 4, Fig. I and 62, Fig. 18). The principal area of the Chud-toponyms and the southern boundary of Finnic hydronyms (see also Map II). 


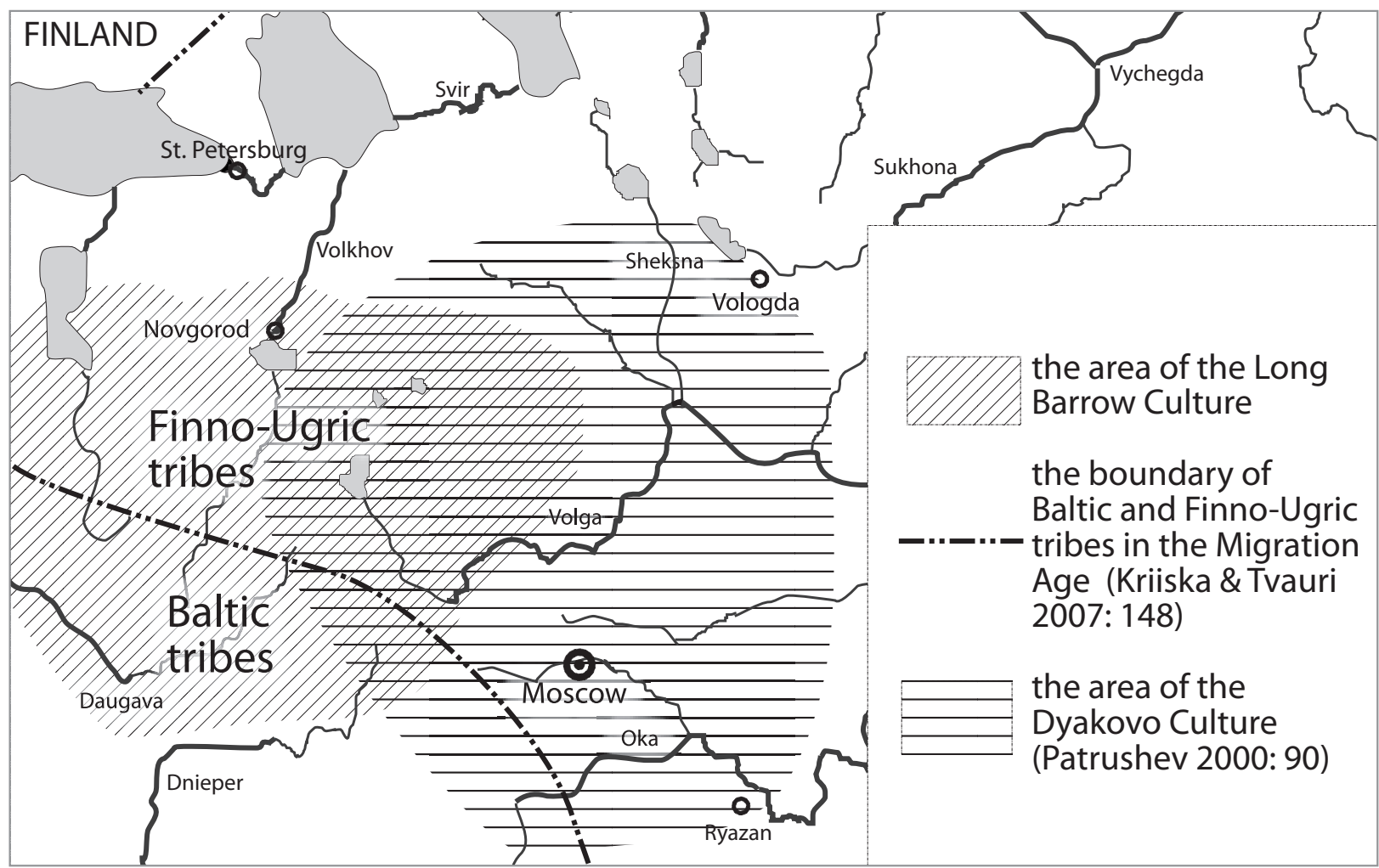

Map 2. The boundary of Finno-Ugrian and Baltic tribes in the Age of Migrations (Kriiska \& Tvauri 2007: 148).

\subsubsection{Dyakovo Culture ( 9 th century BC-7th century $A D$ )}

Many archaeologists consider the areas west of Moscow to have been settled by both Baltic and Finno-Ugrian tribes during the Late Dyakovo Culture (3th-7th centuries AD) and the Long Barrow Culture (5th-10th centuries AD) (see Ryabinin 1997: 151 and attached literature). Already in the Early Iron Age, the Dnieper-Dvina Culture (called днепродвинская культура in Russian) had regional characteristic features. In the western area, the material of the Scratched Surface Ceramics typical in Baltic countries was more influential, and in the Upper Daugava there was more prominent influence of the Textile Ceramics and Dyakovo Culture, which are usually considered Finno-Ugrian (Yemifinova 2001:25-27; Korotkevich 2001: 28-29). In the archaeological site of Yabara close to Pskov, long barrows are found with objects that, according to Mikhaylova (2001: 39), show intensive interaction between the Long Barrow Culture and the Late Dyakovo Culture. Tvauri (2007: 252-254) also writes about the connection of the archaeological material of excavations in Pskov Castle with the Dyakovo Culture. However, the Dyakovo Culture (see Maps 2 and 12), is problematic because the definition of its boundaries is difficult. In the literature there exists 
a minimalistic, Moscow-centric view (e.g. Rozenfeldt 1974, Fig. 48) or a wider view that includes the Upper Volga and Oka area (e.g. Patrushev 2000: 90; Makarov 1999: 55; Tretyakov 1966: 145-153; Goryunova 1967: 75). If the wider view is correct, a considerable part of the Novgorodian Chudes most likely lived under the influence of the Upper-Volgaic Late Dyakovo Culture.

\subsubsection{Medieval Novgorod}

The earliest archaeological material of the site of Ryurikovo, the predecessor of Novgorod, has been dated to around $850 \mathrm{AD}$ and the earliest material of Novgorod itself to around 925-950 AD (Uino 2006: 356). There existed a suburb called Nerev|skiy konets and a street called Chudintsevaya ulitsa in the late medieval Novgorod (ibid. 2006: 368). ${ }^{6}$ In the Upper Volga area, the corresponding toponyms with Nerevskiy < *ner(e) *mer(e) are linked to the Meryans (Ahlqvist 1999: 627).

Pendants with horse and bird motifs are found in the suburb of Nerevskiy Konets. They were manufactured in the 13th and 14th centuries, and are commonly thought to have been made by Chudes (Uino 1997: 191, Fig. 6:14.). Altogether at least 64 horse-motif pendants have been found (ibid. 1997: 192 reference to Sedova 1981: 28-34; Ryabinin 1981). The motifs of horses and birds are very common in the FinnoUgrian cultures of the Oka and Upper Volga area. A figure of a horse-shaped pendant presented by Ryabinin (1997: 182, Fig. 47, object 10) can be taken as an example. This pendant was found in the Uglich region of the Upper Volga area, close to the site called Chudskoy Stan. ${ }^{7}$ It belongs to the group V according to the classification of Ryabinin, as do the Novgorodian pendants as well. The Uglich pendant belongs to the type XIX, but the Novgorodian pendants belong to type XX (Ryabinin 1981: Katalog nakhodok, numbers 639-642).

According to Ryabinin, the Uglich-type horse pendants have been found especially in the Kostroma Volga and on the isthmus between Lake Ladoga and Onega. Horse pendants of the Novgorodian type have been found also in the north-west corner of the Novgorodian Land (Ryabinin 1997: 49, Fig. 13.). It is noteworthy that the type represented by the Uglich pendant is not common in the Meryan core areas. Accordingly, Ryabinin (1997: 189-181) assumes these findings to have been made by some subgroup, different from the actual Meryans. Proper Meryan horse-pendants represent the type XVII (according to Ryabinin) and are found especially in the vicinity of the River Nerl [of the Klyazma catchment area] as well as in the surroundings of the town of Murom (Makarov 2006: 277). Thus, Nerevskiy Konets and Chudintsevaya ulitsa may, indeed, be connected with the Chudes, who in that case continued the tradition of the Upper-Volgaic art of horse-shaped pendants in Novgorod as late as the 14th century AD.

6 From an anthroponym Chudin 'a Chude'.

7 Stan was an old Russian administrative term. 


\subsection{The old Russian chronicles}

The ancient Russian chronicles describe many ethnic groups, e.g. Chudes, Meryans, Muromas, etc. When I have discussed these with specialists of various disciplines, they have expressed many doubts concerning the reliability of the ethnographic picture drawn by the chronicles. It seems to me very curious that the mention given by the Povest vremennykh let (PVL) of Mordvins, Cheremis, Livonians, Kurians and Zhemgalians are taken as reliable, but the mentions of Chudes and Meryans have been questioned only because they have no continuous presence up to modern times. Of course the PVL, like most ancient chronicles in general, is biased when describing e.g. the higher morals of the Polyans compared with other ethnic groups (Lind 2006: 257). Nonetheless, the description of the ethnic groups seems reliable because these groups are presented in the correct geographical order. Peoples who paid taxes to the Russian state are mentioned in the following order: [Novgorod-Tver-Belozero area]: ${ }^{8} u y \partial b$, весь || [Volga-Oka area]: меря, мурома, черемись, мордва || [north-eastern area]: птормь, печера || [Baltic area]: ямь (Yam Vote; see below), литва (Lithuania), зимғггола (Latvian Zhemgals), корсь (Latvian Kurians), нерома (an unknown Baltic group), либь (Livonians) (PVL). On these grounds, my opinion is that there is no reason to doubt the real existence of the nations known by the Slavs as Chude, Merya and Muroma. This is proven also by the ethnonymic toponyms that have been preserved until modern times (see below Section 7; Saarikivi 2006b: 52).

PVL describes the early stage of the Russian state in the light that the Chudes were close allies who participated in various military campaigns organized by the princes of Kiev as a part of the common army (Lihatshov 1994: 20,24). At a later stage, which PVL places in the year 1030, there was a conflict with some Chudian group. After this event the town of Yuryev $\sim$ Tartu in East Estonia was founded (ibid. 1994: 96). These Chudes may have been south-eastern Estonians, the ancestors of the Setu people. Slightly later, in the year 1042, there was a military conflict with the Yams (ibid. 1994: 99). I would interpret the Yams as being the inhabitants of the town Yamburg $\sim$ (modern) Kingisepp region, and thus these people were Votes, close relatives of the Estonians. These conflicts seem to reflect the atmosphere of rebellion among the Finno-Ugrians. The reason might be a tension between Christianity and paganism that is constantly reported by the PVL. A very typical story from the PVL tells of a discussion between a Novgorodian Christian and a Chudian sorcerer in the year 1040 "in the Land of the Chudes" (Lihatshov 1994: 115). The story reflects the difference between the Slavic Christian towns and the Chudian pagan countryside. In any case, the chronicler wished to express that the Slavs were Christian and the Chudes heathens. Nonetheless, it seems that at least in the early stages of the Russian state, the migration of Slavs continued rather peacefully, leading to a gradual change of language from the Chudian original to the Russian prestige language.

8 The brackets and text within are added by the author. 


\section{Research material and methods}

In the following I present methods of onomastics thoroughly, because the toponyms in the present study are very demanding and therefore valid methods are needed. The problem is first of all due to the lack of research history, and secondly to the fact that there is no successor of the language(s) behind the substrate names. The latter point especially makes it very difficult to find reliable etymologies.

\section{I. Names under investigation}

\section{I.I. Material of toponyms}

At first it must be mentioned that the object of this research are names of large bodies of water. Macrotoponyms are usually preserved better than other toponyms (Ainiala et al. 2008: 122-125). ${ }^{9}$ As for microtoponyms, $71 \%$ of the toponyms of Kurhila village in Asikkala parish in Finland have disappeared over the course of 200 years. The loss in Närhilä village in Ristiina parish is even higher at 81\% (ibid. 2008: 122-123). Therefore, it is reasonable to assume that only a very small amount of microtoponyms named by the Chudes some 500-1000 years ago can be preserved.

The name material of the River Volkhov and Luga catchment area has been collected by choosing hydronyms from the maps Atlas Novgorodskaya oblast (ANO) 1: 200000 and Obzorno-Geograficheskaya karta (LPNP) 1:400 000 (see References). In addition, I have utilized the material collected by Vasmer and published in his Wörterbuch der Russischen gewässernamen I-V (1961-1969). Toponyms collected from maps are problematic. Firstly, maps may contain mistakes. Secondly, most of the microtoponyms will be ignored. Thirdly, it is not possible to reflect variants. The small amount of microtoponyms is compensated by the fact that the names of large bodies of water occurring in maps are usually older and therefore more relevant than those of small bodies of water. Even though a larger corpus of names collected from the research field would be more desirable, in this case the lack of a large corpus does not hinder achieving an adequate result.

\section{I.2. Substrate vocabulary and toponyms}

When researching the substrate names of any particular area, one must choose the names for the corpus. The first question is therefore which names among all the toponyms are substrate names. Here I will not discuss the theories of the mechanisms that produce substrate names. Saarikivi (2006a: 11-25; 2006b: 15-52) has written of this subject in two articles. When defining the substrate names and vocabulary of

9 The term 'macrotoponym' is used here when referring to names of larger bodies of water, which usually are older than microtoponyms (names of meadows, fields, small brooks). 
the Saami linguistic area, Ante Aikio (2004: 5-34) has followed the criteria presented by Salmons (1992: 267): 1) in the modern dominant language there must exist a sufficient amount of vocabulary from an unknown source; 2) the vocabulary of toponyms is concentrated in the segment where substrate words are highly presumable; 3 ) linguistic structures that are not typical in the dominant language are frequent in the words; 4) irregular phonetic correspondences occur between the languages or dialects which reflect loanwords from a substrate language. In the present research it might suffice to state that in North and Central Russian dialects a great deal of substrate vocabulary occurs and - typically for substrate words - it is related to geographic terms, fishing, hunting, etc. (cf. Saarikivi 2006a: 39-41).

Kiviniemi has discussed the question of original languages reflected in the toponyms of Finland. According to him, toponyms can be studied by comparing toponyms outside of historically known linguistic areas and searching for names which are alien to historically known settlement. In both cases the phonetic relations of adopting loanwords from one language to another create an additional problem (Kiviniemi 1980: 320; Matveyev 2001: 123-126). Saarikivi also believes that it is not sufficient to examine the toponyms of the research area only, but it is necessary to also study toponyms from areas where the substrate language is probably still spoken. However, according to Saarikivi, in several cases one must be content with utilizing the material of cognate languages, because the substrate language may not be sufficiently known (Saarikivi 2006b: 16).

In the present research I have followed the methods of Kiviniemi and Saarikivi in order to select the corpus of toponyms. I have searched for toponyms alien to the Russian language. By comparing the toponyms of neighbouring areas with each other, it is possible to outline the focus areas of different toponyms and name types. The areas of comparison are Tver and Yaroslavl oblasts and the Oka and Svir catchment areas. To some extent the toponyms are compared also with those of Finland and the western parts of Kostroma and Vologda oblasts. The languages compared are mainly Mordvin and Finnic, as these are the most presumable cognate languages.

\subsection{Lexical, phonetic and structural factors}

The starting-point of the research is that there are certain linguistic reasons to believe that a name originates from the predecessors of the modern dominant population. The linguistic reasons may be lexical, phonetic or structural.

\subsection{Lexicon}

When a lexicon that does not belong to the dominant language occurs constantly in toponyms, these toponyms can be suspected to be linked with a substrate language. It is not always easy to recognize toponyms as substrate names, for example because words disappear from languages (Kiviniemi 1990: 38 referring to Nirvi). Such names 
look as obscure as proper substrate names. Old anthroponyms are especially difficult to attest. They seldom occur in names of large bodies of water, but instead are visible in names of fields and meadows and in oikonyms attached to those. In Finland such ancient anthroponyms include for example Ikali, Hollo and Paro, from which the oikonyms Ikaalinen, Hollola and Parola are derived (NA). The global evidence presupposes that also in the present research area, there should be numerous toponyms derived from anthroponyms. They are introduced to some extent in Section 5 alongside with the formant -lya.

\subsubsection{Phonetic points}

Phonetic features may reveal a toponym as a substrate name. Saarikivi (2006b: 15) refers to variants of what were originally identical words in toponyms, such as Kukas|järvi, Kuukas|järvi, Kuukka < SaaN guhkes < Proto-Saami *kukkē 'long'. It is the irregularity that expressly reveals a substrate language. There are many similar examples in the Oka catchment area, such as the variants of the rivers Konshur Konchur (GBO231) and Konchura $\sim$ Konshura $\sim$ Konshchura $\sim$ Konsyera (GBO198). The variants of the second syllable consonants $\check{c}, \check{s}, \check{s}^{\prime}, s^{\prime}[u, u, u, c(e)]$ point to a non-Russian original. In the background there might be a Finno-Ugrian affricate ${ }^{*} c$ or a sibilant $*_{s}^{\prime}$.

\subsubsection{Structure of names}

Matveyev (2001: 73-75) believes it is important to pay attention to those morphological regularities which can be considered sufficiently absolute and frequent. In his view, it is important to note the regular frequency of formants and generics of toponyms. The structure of Finno-Ugrian toponyms often consists of what, in the Finnish terminology, are called a specific (Finn. määriteosa) and a generic (Finn. perusosa). For example, in Jänis|järvi, jänis 'hare' is a specific and järvi 'lake' a generic. The same structure is found also in other Finno-Ugrian languages, e.g. Mari Shem|yer < *Šem|jer 'black lake'; Mordvin In |erka < Ińe erke 'big lake'; *Meryan Peche $\mid$ khra < *Pečejäyralä 'pine lake' (Ahlqvist 2006: 16). In Russian a toponym may be based on a noun construction, such as река Медведка 'Bear River', or on adjectives as in озеро Медвежье 'Bear Lake'. A generic element, typical of Finno-Ugrian toponyms, did not exist in the original Slavic naming system..$^{10}$ A generic is attached to the Finno-Ugrian (and Baltic) naming system to express the nature of the place; e.g. Pää|järvi where järvi 'lake' is a generic (Kiviniemi 1990: 106). Thus, any toponym in the research

10 For example, in the Karelian Republic in the Russian Federation, a structure similar with the FinnoUgrian system commonly occurs: Vedl|ozero, Syam|ozero, etc. These are partial translations from the originally Finno-Ugrian names Viel|järvi, Säämä|järvi. 
area which has a formant (a kind of affix; see below) with the original meaning 'lake' or 'river' (e.g. -(y)er, -khra, -yuga) is most likely of Finno-Ugrian origin.

I must briefly explain the terminology connected with the structure of toponyms that is used in the present article. Russian onomastics uses the terms основа 'base' and топоформант '(topo)formant'. When treating Finno-Ugrian toponyms, Matveyev (2001: 188-248) also uses the term детерминант 'determinant' that usually refers to generics. Because the present research concerns hydronyms in Russia, I have thought it useful to observe the Russian terminology to some extent. The term formant is especially useful. Formants are connected with a stem of a name. However, the terms specific and generic used in Finnish terminology are preferable expressions concerning Finno-Ugrian substrate names, in contrast with the Russian 'base' and 'determinant'.

Saarikivi (2006b: 18) has defined formants as phonotactic types of single-morpheme opaque toponyms having a characteristic feature that makes it possible to understand the word as a place name. An example is the Central Russian hydronym Kolo|ksha, where kolo- ?'fish' is the stem of the hydronym and -ksha the formant. In the background of formants there are generics and derivational affixes that have been obscured.

There are several different Russian suffixes occurring in Russian toponyms, such as an affectionate or diminutive suffix $-\kappa a$, a possessive suffix -ов/-ев (an old genitive), etc. Usually, but not always, possessive suffixes in toponyms refer to an anthroponym origin. Russian suffixes are also connected quite commonly with toponyms of non-Slavic origin. In using the term suffix for Russian-language elements, I follow in this respect Irma Mullonen's terminology (Mullonen 2002: 69-105).

There may exist formants, generics, suffixes and derivational affixes whose boundaries are ambiguous and hard to define. Undoubtedly, many formants were originally derivational affixes. A good example is the lake Päijä|nne in Finland. The derivational suffix -nne $<*_{\text {-nte }}(k)$ occurs in Finnish in such geographical terms as syvä|nne 'deep area in a lake or sea' < syvä 'deep', ala|nne 'low area' < ala 'low', ylä|nne 'heights' < ylä 'above', paina|nne 'depression, hollow' < painaa 'to depress'. According to Saarikivi's definition, it is possible to state that derivational affixes have become formants, because they express that there is a toponym in question and the original meaning of the derivational affix has been obscured. Some formants are attested by old literal documents as originally generics; cf. Must $\mid$ io $<{ }^{*}$ Must $\mid$ oja 'black brook' (Ainiala et al. 2008: 116) or Laut|ua <*Laut|oja 'raft brook' (Räisänen 2003: 186-187); Finnish oja 'brook'. If a formant is connected with an obscure stem from the point of view of a dominant language, there is a good reason to assume that in the background there is a toponym originating from a substrate language. In the present work the terms stem, specific, generic and formant are used in discussing Finno-Ugrian toponyms. In addition, the term suffix is used when suffixal elements of Russian origin are in question. 


\subsection{Toponyms and the language in the background}

A corpus of toponyms to be examined can be created when various alternatives have been evaluated and a large stratum of presumable toponyms of substrate origin are detected in the same area. This raises new questions, the most ethnohistorically important one being to which linguistic connection the toponyms belong. In order to tackle this question, various scholars have utilized methods that are introduced in the following.

\subsection{Formants connected with different types of toponyms and areal distribution}

Toponyms can be classified in types based, for example, on the formants (Ainiala et al. 2008: 39). Mullonen, who has concentrated especially on the hydronyms of the River Svir, has used areal distribution of different types and models of toponyms as one of her methods in order to study substrate names. Accordingly, she has paid much attention to structural characteristics of toponyms. This usually means analysis of formants (Mullonen 2002: 183). In the present research, areal distribution and analysis of formants play a great role as well (see Section 5). If the stem and the formant of a toponym refer to the same areal direction, the toponym presumably belongs to the connection in which this type is principally represented. Formants and generics are important also because they reflect in many cases different phases of a language shift (Mullonen 2002: 85-96). ${ }^{11}$

\subsubsection{Semantic typology}

It is very important to define the most common types and motifs of naming. It is possible to accomplish this by comparing research of semantic typology connected with toponyms of a substrate language (Saarikivi 2006b: 16; Ainiala et al. 2008: 115). One useful method for defining an etymology is to utilize semantic opposites such as big-little, upper-lower, black-white (Matveyev 2001: 85; Rahkonen 2009: 169-178).

\subsubsection{Comparative linguistic study}

Comparing toponyms with the presumable substrate language is very difficult in the present study, because the language is initially unknown. There is also a possibility that there are several substrate languages. A presumption might lead to a vicious circle and subjective study. For these reasons, the starting point in the present research is more complicated than e.g. in Pitkänen's (1985) studies concerning the Finnish toponyms

11 In cases of partial translations (semi-calque) or changes of formants typical in different languages; see Sections 3.3.4 and 3.3.5. 
in the Turunmaa isles prior to the Swedish-speaking settlement layer, or Saarikivi's (2006b) study concerning the Finnic substrate toponyms in the River Pinega region. Correspondingly, the toponyms of Saami origin in the River Svir area examined by Mullonen (2002: 228-290) can be compared with the modern Saami languages and with the Proto-Saami reliably constructed on the basis of these languages. Thus the researchers mentioned above had a relatively clear standard of comparison, making the etymologies remarkably more reliable. The task becomes much more complicated when the substrate language is extinct without leaving any direct modern successor. The speech of the Novgorodian Chudes was exactly such a language (or languages). On the other hand, the situation is better than in the work of Aikio (2004) concerning substrate toponyms prior to the Saami era, because in that case there was no point of comparison. As a result, he was content with presenting a list of these toponyms, which is a quite acceptable result of his research in this case.

\subsubsection{Productivity of the types of toponyms}

One of Mullonen's methods is to examine productivity of types of toponyms. For example the formant -la of old Finnic oikonyms has changed into the Slavic formant -ichi (Mullonen 2002: 183). This helps us to date contacts between Finnic tribes and Slavs. In the Novgorod Land it is not possible to enter deeply into the productivity of models of toponyms, because the area in question was russified so early that there is insufficient documentary material of hydronyms originating from substrate language(s). This subject has been treated to some extent in Section 5 under the title of formant -lya.

\subsubsection{Partial translation}

It is well-known that newcomers or speakers undergoing language shift often replace generics of names with the correspondence in their own language, but leave specifics in their original form or adapt them phonetically to their own language. This process - called in Russian полукалька 'semi-calque' by e.g. Mullonen - has been attested practically in modern times in the Republic of Karelia and in the area of the Svir catchment area; e.g. Finnic Hiim $\mid$ d'ogi > Russian Гим|река 'the River Hiim' (Mullonen 2002: 105-106).

If an original generic can no longer be recognized as a generic, the result may be an epexegesis. Such an interesting naming has taken place in the headwaters of the River Oyat, especially in the region of its tributary the River Sondala (MAG 43-48), where such forms of hydronyms as Ind|är|järv, Syv|äŕ|järv, Kal|aŕ|järv, and Pad|aŕ|järv occur (MAG 44-45). It seems that the toponyms there reflect two different Finno-Ugrian (or Finnic) layers. The speakers of the latter stratum (Veps) seemingly did not understand the element -aŕ-/-är'- to be a generic ?<*järi 'lake' and suffixed the word järv from their own language. 
One can assume that the more generics of a substrate language are represented in modern times, the stronger the position of the speakers of a substrate language was for a long time. If so, the change to Russian speech did not happen through a migration but through a relatively slow language shift, a situation where long-term bilingualism is presumable. During the process of the language shift, the bilingual population had no need to replace generics with Russian counterparts, because the original meaning of the generics was still understood. By the end of the process, the meaning was finally obscured and generics became pure formants. This is the case e.g. in the upper course of the River Msta, where the formant -dra, connected with lakes $\left(<*_{j} \ddot{a} d r a / \ddot{a}\right.$ 'lake'), has been largely preserved (see Section 5, formant -dra, Map 7). Similarly the lakes in the vicinity of the town of Vladimir have widely preserved the formant -khra until modern times (Map 7). It can be derived from the word *jäpral ä 'lake' that belonged to the substrate language of the region (seemingly Meryan-Muroma). The word is attested by the $Я x p$-lakes [Yakhr-] (see Ahlqvist 2006: 12).

\subsubsection{Ethnonyms}

Ethnonyms should be carefully noted, even though they are problematic. It is not always clear what those who named the toponyms meant exactly when using an ethnonym. For example, Karelians referred to Finns with the ethnonym ruotši 'Swede' (SSA III 108). If in a particular geographical area similar ethnonyms occur widely enough, their testimony increases remarkably. Also Matveyev (2001: 65-71) has introduced them as useful tools of onomastics. I have earlier used this method to some extent when trying to define the core area of settlement of ancient Meshchera in the region of the River Oka (Rahkonen 2009: 168-170, Map 1).

\subsection{Etymologies based on substrate names of extinct languages}

As presented above, I have followed many principles similar to those of Aikio, Matveyev and Saarikivi when collecting the corpus of hydronyms. Mullonen and Ahlqvist took their starting point in smaller collection areas that they then broadened to larger entities for further examination. Following Aikio, I have had to lean on previously gathered material or map names because my research area is very large. ${ }^{12}$ In this sense the present study comes close to Vasmer's early work Die Alten Bevölkerungsverhältnisse Russlands im Lichte der Sprachforschung (1941). In a study like this, phonetic matters become even more important. A study of comparative research of extensive entities of toponyms is important as well. Similarly, Matveyev $(2001,2004,2007)$ has examined large entities in Northern Russia, but he additionally chose smaller subregions from among these large areas (ibid. 2004: 111-187).

12 Aikio's research area in his article 'The study of Saami substrate toponyms in Finland' (2007) is the whole of Finland. 
The object of the present study is to examine toponyms based on extinct languages. Thus, many of the methods of defining etymology used by other researchers are not valid, as those are based on known languages or reliably derived protolanguages. Because there is no continuation of those languages, one must choose as the etymological starting point primarily comparisons with the presumable closest cognate languages and reconstructed proto-languages. One can assume that in most cases the best results are offered by the Finnic languages and Mordvin. To some extent Mari and Saami can be referred to as well.

There are some words occurring in the toponyms of the Meryan area as defined by Russian chronicles that have been reconstructed quite reliably on the grounds of their

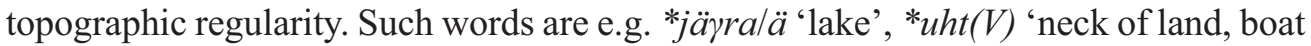
dragging road over dry land', *ner(e) 'Meryan', *veksa 'river between two (bigger) waters', *il(e)- 'upper', vol(o)- 'lower', *en(V) 'big', *väz(ä) 'small' (Ahlqvist 1997, 2004, 2006; Matveyev 2006: 133-233; Mullonen 2002: 212-213, 291; Rahkonen 2009: 172-180; Tkachenko 2007: 115-116; 1985). In all cases, toponyms of the Meryan area ought to be compared with those of Novgorod and Tver oblasts.

The dialectal lexicon of the Russian language also sometimes allows a reliable definition of the etymology of some substrate names and words behind them; e.g. kub-toponyms (Kubena etc.) can be compared with Russ. dial. кyбbluu 'bog, marsh' (MGT 1970) and Proto-Permian güb 'bog, marsh' (Lytkin \& Gulyayev 1999: 84). Sometimes a reconstructed word from a proto-language is useful, such as PFU *ukti 'track' (Sammallahti 1988: 536) from which the stem or specific Ukht(V)- can presumably be derived. Topographical evidence supports this idea as well.

The probability of grounds for naming is essential when a toponym belongs to those that occur frequently. Grounds for naming in a corpus of toponyms based on vanished languages are usually semantically similar with those of known languages. The most common specifics occurring in areas where Finno-Ugrian languages are spoken number at most around 50. Among these the most phonetically and topographically reasonable alternatives can be found. Saarikivi (2004: 186-187) has presented the 20 most common Finnish specifics of lakes and 20 Saami specifics of hydronyms in Finnish Lapland. The sources of livelihood of these two peoples have influenced the grounds for naming to some extent, but common namings for specifics are 'island', 'long', 'stone', 'big', 'perch', 'hay', 'rock/cliff', 'pike', 'hut'. In addition, general Finnish specifics are 'white', 'black', 'little', 'roach', 'deep', 'curved', 'strait', 'upper', 'middle', 'lower', 'pine' and Saami 'burned area', 'unfrozen', 'lichen', 'place or object for worshipping an idol', 'summer', 'headland' and different species of salmon.

Thus, for example, it is useful to search among the toponyms of the research field for phonetically suitable stems of names that can be compared with presumed kindred languages with the meaning 'little'. In the Meryan region defined by the Russian chronicles, only one suitable candidate is actually found: the hydronyms with the stem vyaz-connected with typical formants of Finno-Ugrian toponyms. This stem can be derived from an original *väz(ä) 'little'. Comparisons can be found for this word, e.g. Mordvin vež and Finnish vähä < *väšä 'little' (SSA III 478). In addition, there 
is topographic evidence for the etymology *väz(ä) 'little' (Rahkonen 2009: 175). It is presumably always possible to find correspondences for the most common FinnoUgrian specifics, and for this reason it is possible to find a phonetically acceptable etymology if there is only a large enough quantity of toponyms. In order to discover the generality of specifics and stems, it is essential to examine a sufficiently large areal distribution of toponyms.

In some cases it is difficult to know whether a toponym in the River Volkhov catchment area should be connected with Finnic or Upper-Volgaic or with languages spoken in the Oka area (?Meryan, ?Chudian). The difficulty arises from the fact that some stems and specifics can phonetically be derived from both Finnic languages and language(s) that, on grounds of toponyms, were spoken in Central Russia. Such

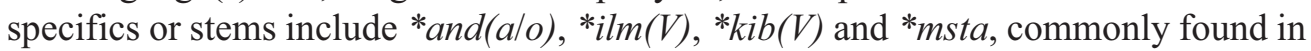
the Upper Volga and Oka area. In such cases formants, core areas of the names and an unbreakable areal continuation of the names have a great importance when reasoning to which of these two directions toponyms in question belong.

However, a fully unambiguous etymology is sometimes difficult to present (see Saarikivi 2006b: 21, table 1). In some cases the topography of a body of water or its vicinity is helpful, when a similar and repeated characteristic in names of a similar specific offers the possibility of determining the etymology with a respectively high degree of certainty (Ainiala et al. 2008: 115). At best a toponym may have two variants, the original version and its Russian translation. However, there must be more than one case of variants to assure us that it is really a matter of translation, and not renaming based on the Russian language. Numerous etymologies of toponyms in the River Svir catchment area presented by Mullonen are based on such variants (Mullonen 2002; MAG). It is important to remember the danger of Russian folk etymologies as well. Sometimes it may be useful to examine names of marshes, hills or settlements around a water system. There is a possibility that originally there was a cluster of specifics occurring in various types of topographic objects in the same small area (e.g. a river, hill, woods or marsh may share the same specific). Some of them may have preserved the original specific better than the hydronym itself. It is possible that the hydronyms have been translated in the process of language shift, but some other object of the cluster has preserved its original form.

\subsection{The problem of adoption}

The adoption of toponyms from a substrate language into a dominant prestige language often creates a serious research problem. Especially in order to track down the correct etymology, knowing the original form of a toponym is necessary. Saarikivi (2006b: 23 , table 2 and 25, table 3 ) has presented tables concerning adoptions from Finnic into Russian in the River Pinega catchment area. Mullonen (2002: 39-72) has attended to the same problem very thoroughly and presented several examples in the River Svir area. Matveyev (2001: 130-151) has also written on this subject concerning adoptions from Finno-Ugrian to Slavic in general. The table below has been constructed on the 
basis of their work, reflecting also the publications of Juhani Nuorluoto (2006) and Jouni Vaahtera (2009) concerning the phonetic history of the Russian language.

\begin{tabular}{|c|c|c|c|c|c|}
\hline $\begin{array}{l}\text { Finno- } \\
\text { Ugrian }\end{array}$ & Slavic & $\begin{array}{l}\text { Finno- } \\
\text { Ugrian }\end{array}$ & Slavic & $\begin{array}{l}\text { Finno- } \\
\text { Ugrian }\end{array}$ & Slavic \\
\hline$t$ & $m, \partial$ (non-initial) & $-\eta(k)-$ & $-H-$ & $a$ & $a, o$ (early) \\
\hline$k$ & $\kappa, 2$ (non-initial) & $S$ & $c, u, 3, \varkappa$ & $e$ & $e, \ddot{e}, a, o$, э \\
\hline$p$ & $n, \sigma$ (non-initial) & $h$ & $x, 2, \varnothing$ (initial) & ee & $e$ \\
\hline$-t t-$ & $-m-$ & $-h k-$ & $-x m-,-8 \kappa-,-\kappa-$ & $i$ & $u, b l$ \\
\hline$-k k-$ & $-\kappa-$ & $-u(C)-$ & $-8(C)$ & $O, O O$ & $o, e$ (late) \\
\hline$-p p-$ & $-n-$ & & & $u$ & y, oy (early) \\
\hline$m$ & $M, H$ & $\check{c}, \dot{c}, c$ & $\varphi$ (non-Finnic) & $\ddot{u}$ & $ю, y, b l$ \\
\hline \multirow[t]{2}{*}{$-m b-$} & $-м б-,-н б-$ & $\partial$ & $\begin{array}{l}o, y, e \text { (non- } \\
\text { Finnic) }\end{array}$ & $\ddot{a}$ & $\begin{array}{l}я, e \text { (early), } \\
a \text { (2.syll.) }\end{array}$ \\
\hline & & & & $\ddot{O}$ & $\ddot{e}, ? b l$ \\
\hline
\end{tabular}

Table I. The most common rules of adoption from Finnic and other Finno-Ugrian languages (Saami, Mordvin) into Slavic. The Slavic counterparts are written in the Cyrillic alphabet.

\section{Remarks on Finnic hydronyms in Novgorod, Pskov and Leningrad oblasts}

As mentioned above, it is often assumed in the literature that the Finno-Ugrian tribes who lived east of Lake Peipus and in the area of the Upper Volkhov were Baltic Finns (see e.g. Grünthal 1997: 159-164 and the attached literature). Hydronyms do not necessarily support this idea. Transparently Finnic hydronyms follow like a ribbon the southern coastal areas of the Gulf of Finland, the Neva River and Lake Ladoga (Map 1). Some researchers have suggested hypotheses concerning the area presented above whose reliability on one hand is not watertight, but on the other hand cannot be denied at once. For example the Kalmistonmäki-Volkhov type Textile Ceramics in the early Iron Age (7th-4th centuries BC) found in the southern coastal area of Lake Ladoga have been assumed to originate from a Proto-Finnic population (Yushkova 2006: 141; Uino 2006: 363). ${ }^{13}$ According to the terminology of Petri Kallio, these tribes later became the eastern group of Finnic tribes who spoke the eastern dialect of the Gulf of Finland (Kallio 2007: 243).

Names of settlements in the area of Novgorod are irrelevant from this research's point of view, because relatively late in the 17 th century a remarkable amount of orthodox Karelians from Käkisalmi county and Ingrians from Ingria moved there as refugees and produced new oikonyms (Kirkinen 1994: 165-171). However, their migration could not change the overall picture of hydronyms. The same concerns the influence of the migration from Savo and Swedish Karelia on oikonyms and hydronyms in the vicinity of Leningrad.

13 An especially important archaeological site is Shkurina Gorka $6 \mathrm{~km}$ south of Staraya Ladoga. 


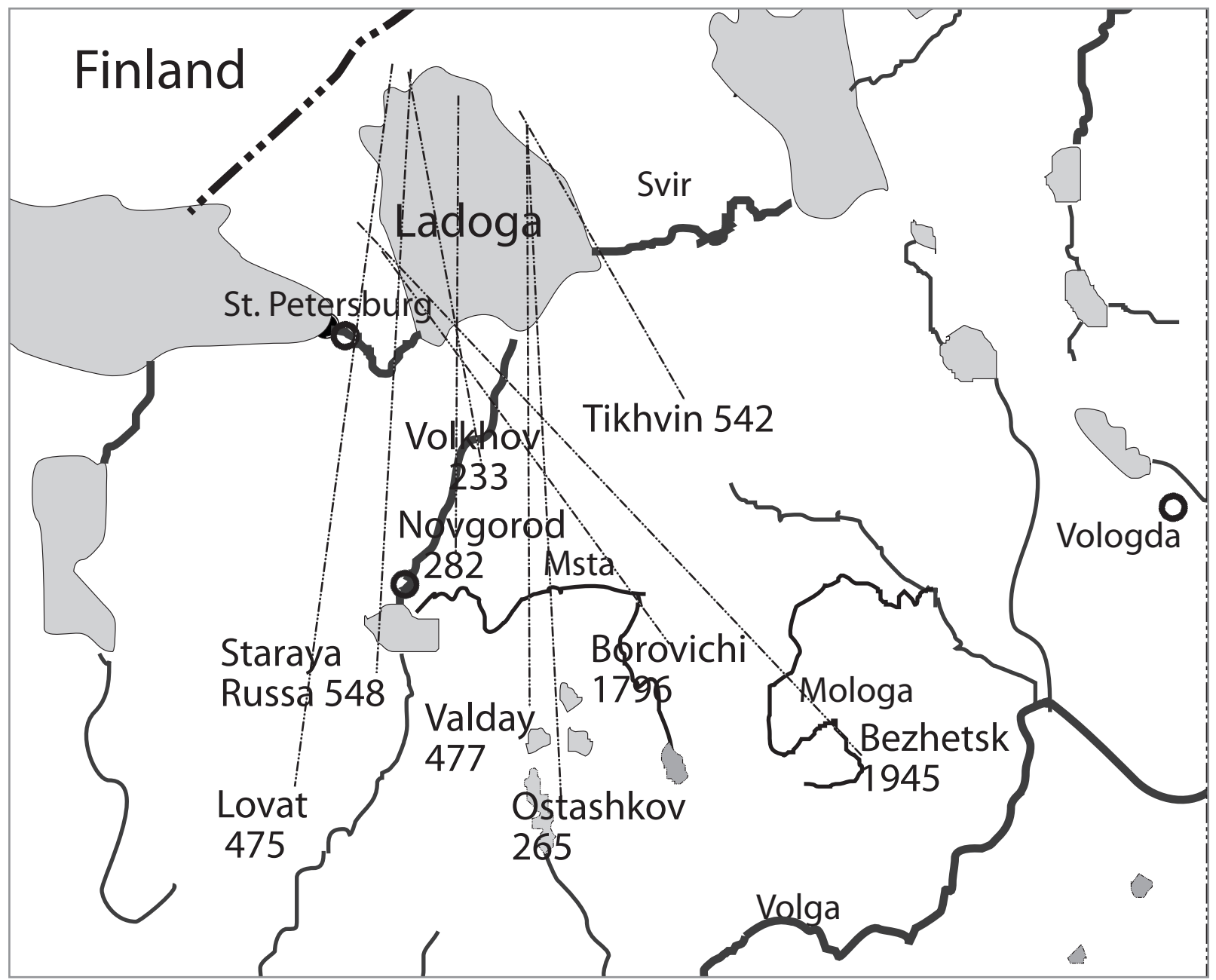

Map 3. Directions and numbers of Karelian Orthodox refugees from Käkisalmi county in the 17th century AD (featuring Kirkinen 1994: 154).

I have divided the possible Finnic toponyms in Leningrad and Novgorod oblasts into two categories. There are names that can certainly be considered Finnic. There are also names whose origin is uncertain. The factors of uncertainty in this work are 1) non-Finnic formants, 2) specifics typical in the Upper Volga and Oka catchment area and 3 ) orthographic factors of uncertainty possibly originating from Russian adoption. 


\section{I. Leningrad oblast}

Finnic hydronyms (visible on Map 4 according to the numbering): ${ }^{14}$

I) Avloga $\sim$ Aulokanjoki

cf. Aula|nko in Finland; the origin of aula uncertain;

possibly $\sim$ Fin. oulu 'flood'

2) Khabolovo oz. Haapalanjärvi 'lake of aspen

(-la-formant refers to a settlement, a farm or a family)

3) Khepoyarvi oz. Hepojärvi 'horse lake'

4) Kostuya *Kostoja 'wet river'

5) Kusega * * Kuusjogi 'spruce river'

6) Kusi|nka *Kuusijoki 'spruce river'

7) Lembolovskoye oz. Lempaalanjärvi 'lake Lempaala';

$<$ lempo 'ancient mythological character'

8) Pinega $\sim$ *Pienjogi 'little river'

9) Sestra $\sim$ Siestarjoki 'currant river'

10) Voitolovka $\sim$ Voittolanjoki < oikonym Voittola $<$ voitto 'victory'

II) Voloyarvi oz. $\sim$ Vuolejärvi < possibly of Proto-Saami origin 'lower lake'

12) Kavgolovskoye oz. Kaukolanjärvi < oikonym Kaukola

13) Azika $\sim$ Asikka < anthroponym Asikka

14) Lava *Lavajoki 'flood river'

15) Kivuya * *ivioja 'stone river

22) Lipyarvi oz. *Lepjärvi or *Lippojärvi 'alder lake' or 'scoop lake'

23) Shuyarvi-Shu, bol. *Šuojärvišuo 15 'marsh of marsh lake'

Possibly Finnic hydronyms:

16) Galmach|ikha ?< Finnic halme 'field'; uncertain, because the word behind the toponym (close to the Lake Peipus) does not occur in Estonian or Vote!

17) Rap lya ?< Finnic rapa 'bog'; the formant -lya is concentrated in Central Russia

18) Okhta ?< Proto-Finnic *okti 'bear'; the hydronyms can be connected with Central and Northern Russian Okhta, Ukhta-names with the meaning 'landneck between two waters'

19) Ukhta? < Finnic huhta 'burn and slash field'; see however Okhta above. The word uhta is not found in Vote. The hydronym Ukhta is located in the Vote area.

20) Voya ?< Finnic oja 'ditch, river' < PU *woja (Saarikivi 2006b: 31). Possibly the hydronym (in the middle course of the Luga) is based on a word derived from a more archaic language.

2I) Volgom $\mid k a ?<$ Finnic valkama 'boat shore'; there are numerous names with volg- in the Upper Volga area.

14 Names with $\left(^{*}\right)$ are reconstructions into Finnic. The others are selected from the collection of NA.

15 Phonetically this name occurring close to Tikhvin seems to originate from the South Karelian dialect and it was seemingly named by Karelian refugees (17th century AD). The Veps form should be Sojärvso. 


\subsection{Novgorod oblast}

No certain Finnic hydronyms found.

Possible Finnic hydronyms:

24) Andolovka ? $<$ Finnic antaa 'to give' (originally food) $>*$ Andola. Hydronyms with and-occur also in Central Russia. The formant $-l(a)$ in names of rivers is quite common in Central Russia as well.

25) Ilmen <*Ilmer'?< Finnic ilma 'weather, wind'. Hydronyms with il'm- are common in Central Russia (Map 5) as is the formant -er (see Section 5, formant -er).

26) Yaim $\mid$ lya $<* \ddot{A}$ imläj ? < Finnic äimä 'needle'. Finnic äimä < PU *äjmä and therefore the stem here is not necessarily of Finnic origin. The formant -lya is very common in Central Russia (see Section 5).

27) Kiba ?< Finnic kivi 'stone'. Kib(V) hydronyms occur also in Central Russia. In the Novgorodian dialect $* v>b$ is usual (Zaliznyak 2004: 55).

28) Kirva ?< Finnic kirves 'axe'. There exists in Russian adoptions of hydronyms Finnic kangaz > Russian канг (MAG 37,83). Accordingly, Finnic kirves could have become Russian кирв-. Kirva can be compared also with the oikonym Kirvu in the River Vuoksi valley in the Karelian Isthmus, which probably originated from an anthroponym.

29) Msta, Mstizhskoye oz. ?< Finnic musta 'black'. Many correspondences of mstahydronyms occur in Central Russia, even in the Lower Klyazma area (Map 5).

30) Oskuya, Oskuyskoye oz. ?<* Oskaoja. However, cf. two Oskom|lya in Tver oblast (ATO94, 123) ?< anthroponym Oska that can be compared with the Uska names in Finland.

3I) Rabe|zha ?< Est. raba 'bog'. The river flows in a marshy area, but on the other hand the formant $-\check{z} a$ is very common in Central Russia (see Section 5).

32) Voldom $\mid$ itsa ? $<$ Finnic *valkama. Through Russian adoption *valkama $>$ волдома is phonetically possible. However, voldom hydronyms occur also in the Oka catchment area.

It is worth noting that in Leningrad oblast, the certain cases are much more frequent than the uncertain ones, while in Novgorod oblast certain cases do not exist. There are nine (9) hydronyms whose uncertainty is based on frequent correspondences of specifics or stems in the Upper Volga or Oka region and again others whose formants refer to Central Russia.

The hydronyms Oskuya and Kirva may represent cases where either the modern form of the names have possibly changed when they were adopted into Russian (? *oks- > osk-, ? *kirves $/ z>k i r v-)$ or those names are not of Finnic origin. The element -uya, however, can be derived from Finnic original *oja 'ditch, river' (Matveyev 2001: 258). This makes the Finnic origin of the name more probable. The river (and lake) Oskuya is located not far from the historically known Veps territory. The hydronym Kirva can be attached to the toponym Kirvu in the River Vuoksi valley. This name may have been spread by Karelian refugees from the River Vuoksi area. 
In Tver oblast there are some hydronyms that can be interpreted as Finnic: Khit $\mid k a<$ oikonym Khititsy (ATO178B3) < Finnic *hiite 'demon, pagan worshipping place', Yarvy oz. (ATO99A4) < Finnic *järvi 'lake', Kagra (ATO57A2) < Finnic *kagra 'oats' or more probably *kägrä 'curved', Kivy (ATO76A1) < Finnic *kivi 'stone', Mushto (ATO76A4) < Finnic *musta 'black'. On areal distribution grounds, all of these are connected with Karelian settlements in Tver oblast (see Map 3) (KKM, maps; Kirkinen 1994: 166, map). In addition, especially the specifics mušta and kägrä or kagra refer phonetically to the Karelian language (KKS III 381; KKM, Map 96). One must remember that these hydronyms are located in the catchment area of the Volga - not the River Volkhov - and thus they are outside of the area under study.

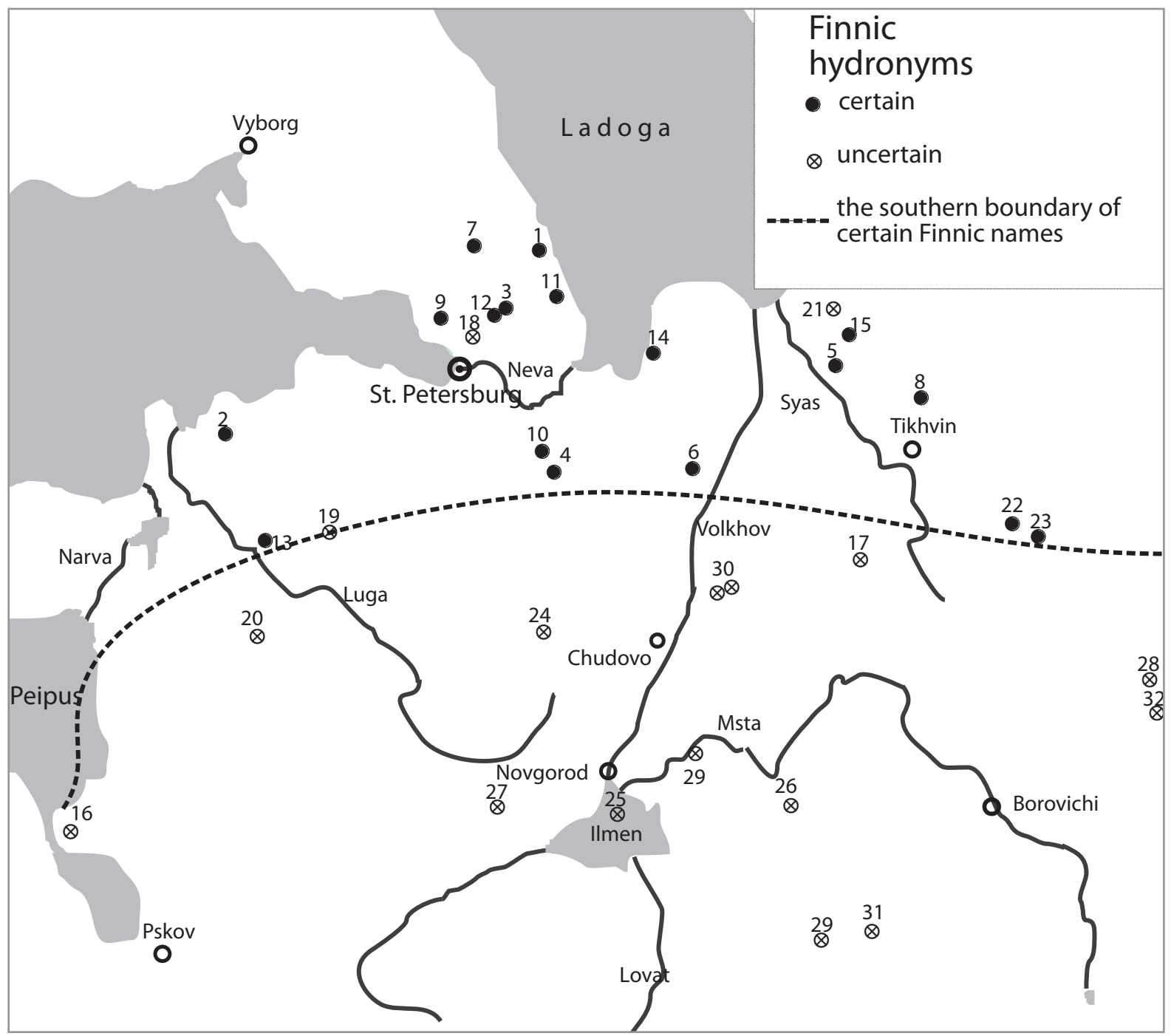

Map 4. Finnic hydronyms in Leningrad, Pskov and Novgorod oblasts 
In Novgorod oblast the names of large bodies of water, Lake Ilmen < * Ilmеŕ $\sim$ Илмърь (e.g. Kuleshov 2001: 76; Mullonen 2002: 234) and the River Msta $<$ Mbcma are often interpreted to be of Finnic origin. However, both of these have many correspondences with stems in the Upper Volga and Oka areas (Map 5). In addition, the formant -er/-or (cf. $I l m \mid e r$ ) is typical in Valday region and in the Upper Volga and Oka regions: e.g. Lam|er|skoye oz. (ANO36), Pud|oro oz. (ATO54), Selig|er < *Serig|er oz. (ATO117), Sud|er|ev'e oz. (ATO142), Tam |or|ža oz. (ATO54), Tum |er|to oz. (ATO256). Ahlqvist (2006: 17-20) has also mentioned some -er/or-names of lakes in Yaroslavl oblast, although according to Matveyev (2006: 207-208) in the proper Meryan area there is not a single certain example. This subject is presented in more detail in Section 5, formant -er.

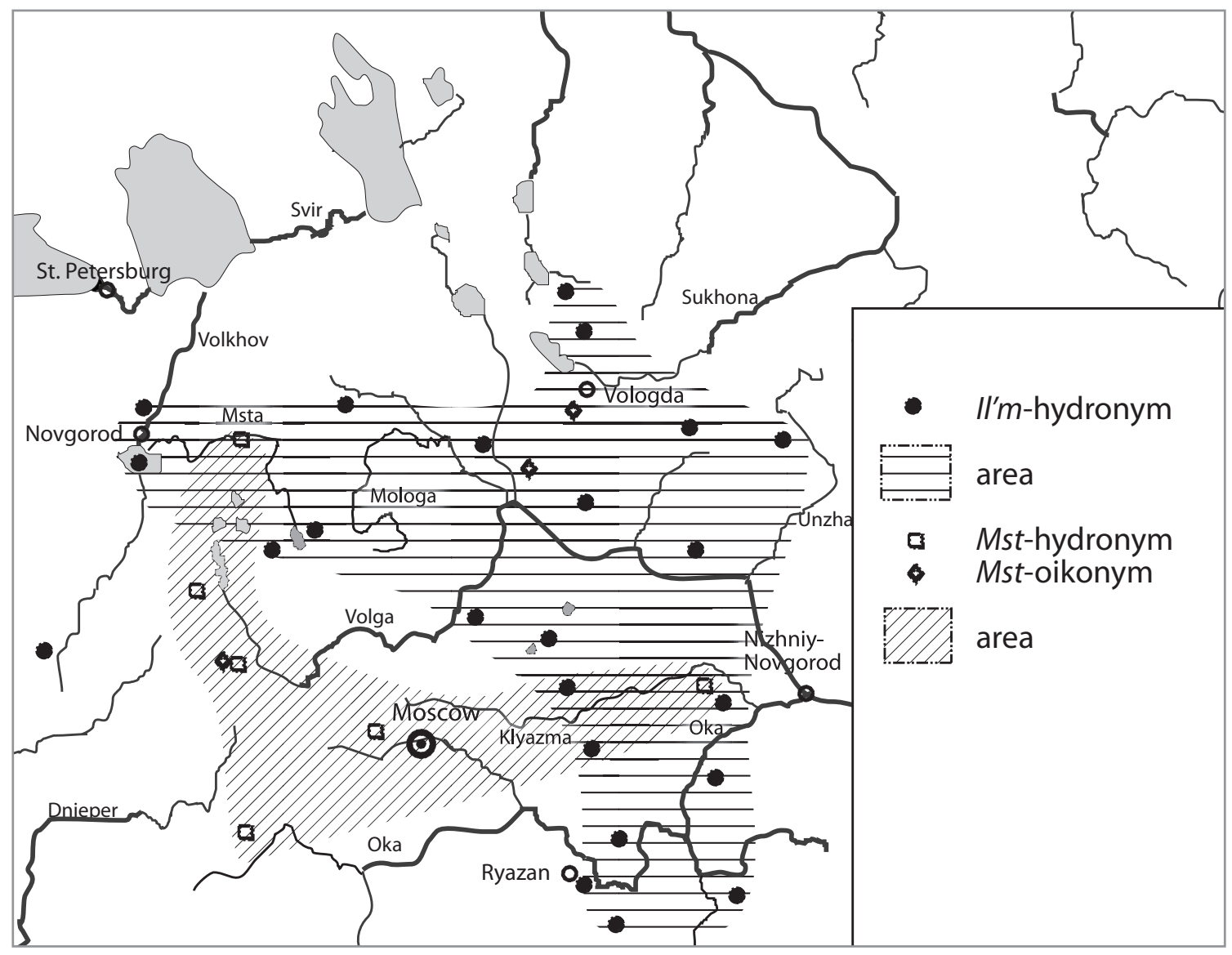

Map 5. Il'm- and Mst-toponyms in Novgorod, Tver, Yaroslavl, Kostroma and Vologda oblasts and in the territory of the Oka catchment area. 
It is noteworthy that in Finland and in Karelia, Ilma-hydronyms with the meaning of 'upper lake' or 'upper river' can be derived from Proto-Saami *ele 'upper' or *elmē 'sky, ?upper part' and were probably adopted from Saami into Finnic languages (Rahkonen 2009: 171, footnote 8). For example, in Ruokolahti parish in Finland, the uppermost body of water is Ilma|järvi (GT2000: 60C4). In the Vuoksi catchment area there is the River Ilmee Ilmet|joki, whose source lake is called Ylimäinen Finn. 'uppermost' (Mullonen 2002: 238-244), while a tributary of the Köyliönjoki is called Ilmiinoja and its source lake Ilmiinjärvi (GT2000: 51E6). In the Finnic-speaking area there are some names where the word ilma apparently means 'wind' (Mullonen 2002: 235 ). It is geographically natural that Lake *Ilmer refers semantically to a upper position in the water system if the idea is to ascend from Lake Ladoga to Lake Ilmen via the River Volkhov. However, a Saami origin for Lake *Ilmer seems very improbable. According to Nissilä, the dialectal word olhava (Volkhov in Finnic Olhava) 'long, deep sloped and wet hollow' occurred as a geographical appellative in the Karelian Isthmus (Nissilä 1975: 28-29). The shores of the Volkhov are in many places very wet, because the difference in the water level between the Lake Ilmen and Ladoga is only 15 metres and therefore the current is very slow causing floods. It is possible that the original meaning of the hydronym Volkhov Olhava was 'long and wet'.

In addition, close to Lake Ilmen and north of it, there flows into the River Volkhov its tributary, the River Kerest, which have headwaters called the Ilmen $\mid k a$ (ANO22A5). Such a narrow upper course could hardly have been named on the grounds of the motif ilma 'wind'. When bearing in mind all the facts mentioned above and thinking objectively, the name *Ilmer should more preferably be connected with the Volgaic regions than with those of Finnic on the grounds of the motif of naming, the formant eŕ, the phonetics and the areal connection (Map 5).

The strongest evidence against the hypothesis of a Finnic Chudian population in Novgorod oblast is the fact that there does not occur any remarkable amount of those Finnic formants and generics that, according to Matveyev, are central markers when

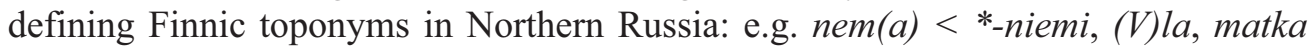
$<*$-matka, randa *-ranta, luda *-luoto, sel'ga *-selkä, koska < *-koski, lamba < *-lampi, salma <*-salmi, korba *-korpi, pelda/palda *-pelto (Matveyev 2001: 297298). The same concerns specifics that, according to Matveyev, are the most common in Finnic substrate names in Northern Russia: e.g. akhn $<*$ ahven, vene $(h)<*$ veneh, vekhk/vakhk < *vehka, ikhal < *ihala, kayd $<*$ kaita, kask $<* k a s k i, k o v k<* k o u k k u$, koy $(b)<* k o i p i$, kolk < *kolkka, kort < *korte, kotka $(s)<* k o t k a$, kuyv $<* k u i v a$, lakhn-/lagn $<*$ lahna, lamb(as)< *lammas, legm $<*$ lehmä, lemb < *lempi, *lempo, lind $<*$ lintu, matk $<*$ matka, myagr-/megr $<*$ mäkrä, myand-/mend $<*$ mänty, peld $<$

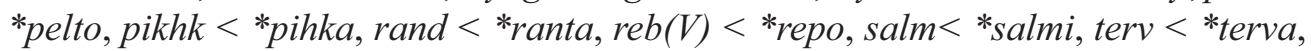
hab/gab < *haapa, khavd/gavd < *hauta, khavk/khauk < *haukka, khain/khein < *heinä, kheb/khepa < *hepo, khid/khit/khiž < *hiite, khim(V) < *himo, khong/gong < *honka, khjarg/khjark/kherg/kherk < *härkä (Matveyev 2004: 33-80).

Here it is also worth stating that 51 out of the 55 Finnic anthroponyms of the Novgorodian birchbark documents mentioned by Saarikivi (2007) do not occur in 
oikonyms of Novgorod oblast. If a great number of bearers of these names had lived there, those names should be reflected in oikonyms. Four (4) uncertain names are found: the anthroponym Libins (2007: 210) the River Libya [Valday], the anthroponym Vělbjakazъ (ibid. 2007: 215) oikonym Velyash|eva Gorka [Luga], the anthroponym Ikagals (ibid. 2007: 220) oikononym Ikand|ovo [Valday] and the anthroponym Mělič̌ (ibid. 2007: 222) oikonyms Melecha [Valday] and Mele|gusha [Tikhvin]. ${ }^{16}$ It is worth noting that these oikonyms are located both in Valday and on the boundaries of historically known Finnic settlements close to the towns of Luga and Tikhvin. In Valday and in the area of Luga as well, the influence of Karelian and Ingrian exiles on toponyms is very possible.

The anthroponym $U d a$, occurring in the document no. 124 (Saarikivi 2007: 226227), is worth mentioning here. As Zaliznyak (2004: 658) has stated, Uda toponyms are widespread in Northern Russia and in Novgorod, Pskov and Tver oblasts as well, e.g. Uda (ANO6-7V1) [Dedovichi, Pskv obl.], Uda|l oz. (ANO39V4) [Borovichi, Nvg. obl.], Uda|kha (ANO31G1) [Porkhov, Pskv obl.], Udo|vishchi (ANO26A3) [Ljubytino, Nvg obl.] and Udo $|m| l y a$ (ANO40G3) [Udomlya, Tvr obl.]. Because of this wide distribution, it is presumable that at least in the Pskov-Novgorod-Tver area $U d a$ was an ancient anthroponym used by the Novgorodian Chudes. Saarikivi (2007: 227) suggests that this name from the birchbark documents originated from an old Finnish anthroponym *Uta $>$ Utula, Utti, Utupää, but he also states that its etymology is uncertain. This name may be based on such an ancient lexicon that it was common both in Finnish and in the (Novgorodian) Chudian language.

\section{Formants of hydronyms in Novgorod oblast}

-oda $(-0 \partial a)^{17}$

This formant also occurs in Northern Russia: Vong $\mid$ oda [Kotlas], Vong $\mid$ uda [Onega], $\operatorname{Volg} \mid u d a$, Lamb $\mid$ uda, Novg $\mid$ uda, Chemb $\mid$ uda, Tun $\mid$ uda <*Tung $\mid$ uda [Sev. Dvina], Tung|uda [Belomorsk]. Matveyev (2004: 21) believes that the formant originates from an old Finno-Ugrian adjective suffix *-(e) $\delta a / \ddot{a}$; cf. Veps korged 'high', *valged 'white', Mari volgâdo 'bright'. The formant also occurs in Central Russia in the catchment areas of the River Kostroma and Nerl [Klyazma catchment area]: Udg|oda (AJO41), Sukh|oda (GBO214), Shikh|oda (GBO214). Matveyev's view of the origin of this formant is not necessarily correct. For example, Lamb $\mid$ uda < Finnic lamb 'pond' and Vong $\mid u d a<$ Finnic voyka 'deep point in a river' are not based on adjectives as the hypothesis of Matveyev presupposes.

16 In the Upper Oka the hydronym Melech|eva occurs. Melecha in Valday should perhaps be connected with it and thus would be of non-Finno-Ugrian origin.

17 In Novgorod oblast: Chag|oda (ANO13A5, ANO19B5), Chag|od|oshcha (ANO6-7A8), Chag $\mid$ od $\mid$ skoye oz. (ANO34B2), Tig|oda (ANO12G2), Tig|oda (ANO14A2). 
Most of the stems of hydronyms connected with this formant cannot be derived from the Finnic languages. Phonetically impossible are Chagoda and Chembuda, because of the initial $* \check{c}$. Lexically non-Finnic are Tigoda, Tunuda, Udgoda, Sukhoda, Shikhoda and probably also Novguda. The stem volg- may not be connected with Finnic with certainty, because it has many correspondences also in the Upper Volga area.

Interestingly enough, the formant -oda/-uda regularly follows the plosives $g$ (or the spirant $* \gamma<* g$ or the combination $* \eta g ?<*-g g-)$ and $b$. This seems to refer to a clear phonetic regularity. I would presume, as one alternative, that in the background one can find the word $* j o \gamma(V)$ or *jog $(V)$ 'river', from which $>-o d a$. As visible in the names of lakes in the region of Valday, the formant -dra being connected with lakes (see below formant $-d r a$ ), it seems that the plosive $*_{g}(?>\gamma)$ has been replaced by $d$, e.g. *jäqralä or *jägralä $>$ jädralä 'lake' $>$-dra. Correspondingly the development *joja or *joga 'river' > -oda is possible; cf. the River Ioda ?< *joja or *joga (AJO62A1) flowing through the city of Rybinsk as additional evidence for this hypothesis.

The Early Russian sporadic sound shift $* g>d$ (Mullonen 2002: 65 referring to Sokolova 1962: 74-75) is considered to be of Russian origin. According to Sokolova this phonetic shift (regressive assimilation) $*_{2}>\partial, *_{\kappa}>m$, observed also in Russian medieval chronicles, occurs before front vowels and iotas sporadically both in original Russian words and names and in loanwords. It should be reasonable to consider whether this sound shift $* g>d$ of Russian dialects may originate from some previous substrate language (? of Novgorodian Chudes). Some support for this hypothesis may be provided by the variants of the same hydronym in the Svir region: Russian Янг|озеро [Yang|ozero] Veps Jänd $\mid$ ärv (MAG46). In this case, against the presumption, there occurs -ng-in the Russian variant, in contrast with - $n d$ - in Veps. Veps * $g>$ Russian $d$ is possible, but $* d>g$ not necessarily without problems. On these grounds one can assume that the Veps variant originates from some previous substrate language (? Chudian) in which $* g>d$.

$-r a(-p a)^{18}$

The formant $-(V) r a$ occurring in the names of rivers is very common in the Upper Volga and Oka catchment areas, e.g. Cheche|ra Checho|ra (GBO109,148), Kamo|ra (GBO236,258), Kato|ra (GBO230), Koya|ra (GBO129), Koshi|ra (GBO100), Vyaze|ra (GBO255), Voymi|ra (GBO226), Vikshe|ra (AJO37), Cheche|ra (AJO11), Checho|ra (AJO87), Pezo|ra (ATO106). There are also numerous formants of the type -(C)ra: Ist|ra (GBO40,106,107), Kost|ra(GBO217), Kust|ra(GBO270), Mat|ra (GBO195), Pem|ra (GBO255), Pom|ra (GBO265), Sukh|ra (GBO197), Shim|ra (GBO211). This together with the fact that there are several possibilities for the previous vowel $(a, e, i, o)$ shows that the vowel does not belong to the formant itself.

18 In Novgorod oblast: Checho|ra (ANO28V2), Yashche|ra (ANO6-7A1), Bol. Vishe|ra; (ANO14G4), Mal. Vishera (ANO23A6), Bol. Vishe|r|ka (ANO23B5). 
The areal distribution (Map 6) offers the most likely possibility to connect the Novgorodian formant $-r a$ with languages spoken in the Upper Volga and Oka. This is true especially because the Novgorodian (Nvg) specifics of hydronyms have counterparts in Central Russia (CR); cf. Nvg Chechora vs. CR Chechora (GBO109,148) [Moscow], Nvg Yashchera vs. CR Yashcher|ka (GBO111) [Moscow], Nvg Vishera vs. CR Vikshera (AJO37) [Yaroslavl]. ${ }^{19}$ It is possible that the formant in question can be derived from an original generic * $r(h) a$ 'river'.

In old maps the River Volga is called Rha. On the map of Mercator (1595) we find written Volga flu olim Rha 'The River Volga, formerly Rha'. Ortelius (1595) has denoted the Volga as Rha occidental 'western stream' (the Kama was Rha orientalis 'eastern stream'). De Jode \& Jenkinson (1571) has marked Volga Rha 'The River Volga'. On the basis of these maps, it seems that $*_{r h a}>-r a$ was an appellative 'river, stream' (in Meryan-Muroma). This idea is supported also by such variants of hydronyms as Voymi|ra Voymi|ga (GBO226), Sukh|ra $\sim$ Sukh|la $<{ }^{*}$ Suү|läj (GBO197) and the names Nev|ra (GBO223) and Nev|ley (GBO242, 264).

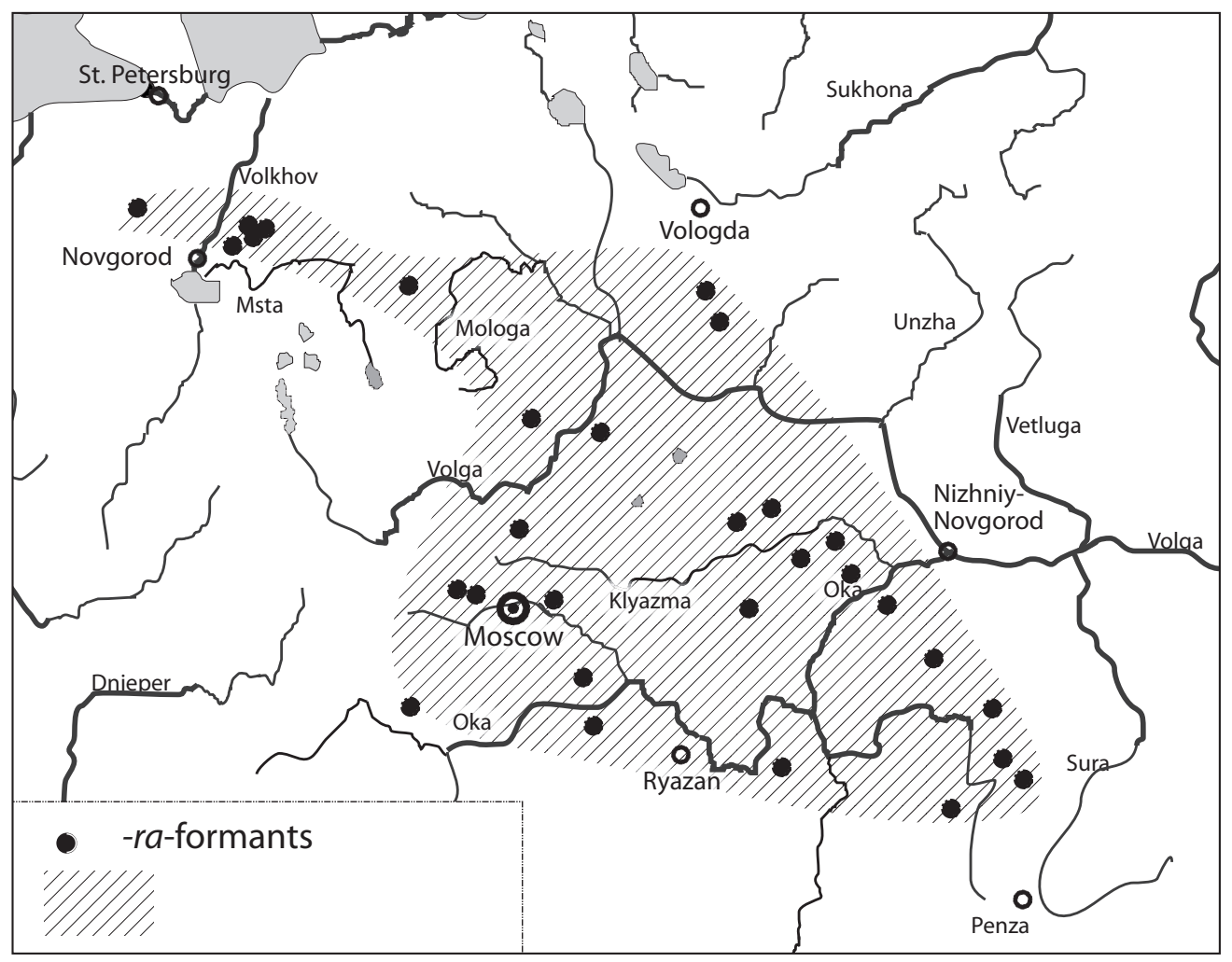

Map 6. The area of the hydronyms with the formant -ra.

19 The variation of $s h \sim k s h$ occurs frequently in the toponyms in Central Russia; see below the formant $-s h /-k s h$. 
$-/ y a(-л я)$

In Novgorod oblast and close to its borders -lya-toponyms are distributed as follows in footnote 20 (numbering according to ANO): ${ }^{20}$

\section{General view}

Ahlqvist (1998a: 29, 44; 1998b: 14) and before her Popov (1974: 20-21, 27) have stated that both formants $-l y a(-л я)$ and $-l$ ' $(-л ь)$ can be traced back to the same origin as Erzya Mordvin lej and Moksha läj 'river'. Saarikivi (2006b: 52) has held a similar opinion. Some variants of the same names support this idea: Mar|ley $\sim$ Mar|lya (GBO241), Tishem $\mid$ lya $\sim$ Tishim $\mid l$ '(GBO16). However, a more detailed study shows that the matter is very complicated and it is possible that the formant -lya has several origins, which have only merged into the same form. In the following I present some alternatives. Most of the -lya-toponyms are names of rivers. In Novgorod (ANO), Tver (ATO) and Smolensk (ASO) oblasts, 37 toponyms are rivers, 20 settlements, 12 lakes and 6 other natural sites. At least 10 of the oikonyms can be derived from names of rivers and many others from the names of lakes and other sites. This proves that -lya in most cases is a formant that is connected with names of rivers.

\section{Areal distribution (Map 7)}

In Novgorod oblast -lya-toponyms are concentrated in the boundaries of Novgorod and Tver oblasts in the headwaters of the River Msta and Mologa. They are numerous also south of Tikhvin. Some toponyms are found west of these areas as well, e.g. Yaim $\mid$ lya $?<* \ddot{\text { Äim}} \mid$ läj [Krestitsy], Tuleb|lya $?<*$ Tulema|läj [Staraya Russa]. The specifics Yaim $<* \ddot{j} j m \ddot{a}$ and Tuleb $<*$ tulema might be interpreted as Finnic, but one should remember that both words can be derived from even Proto-Uralic; cf. PU *äjmä 'needle', *toli 'come' (Sammallahti 1988: 536, 540). In Smolensk oblast a remarkable concentration of -lya-formants is located in the headwaters of the rivers Dnieper and Daugava (Zap. Dvina). Especially in those regions, adoption into Russian has possibly taken place either from Baltic or from Finno-Ugrian languages.

20 Settlements (11) - Gadom|lya (40V3), Khotim|lya (55A2), Loshchem|lya (41G5), *Sitom|lya (67A4), *Sukrom|lya (6-7A7), *Tuleb|lya (33G5), Tukho|lya (35A4), *Tushem|lya (19B4), *Udom|lya (40G3), Zhelom|lya (38A3);

rivers (14) - Tsynov|lya (53A4), Dup|lya (35A5), Izlom|lya (52B2), Yaim|lya (36B2), Korkom|lya (30A3), Nikom|lya (17A5), Pyardom|lya (17A6), Radullya (25A5), Rap|lya (16A2) Ryap|lya (16B1), Sitom|lya (LPNP:L5/N), Sukrom|lya (ATO251A1), Shadom|lya (28G2), Tuleb|lya (34V2); lakes (7) - Chuchem|lya (27V5), Karkom|lya (40B3), Radu|lya (26A2), Retom|lya (17V5), Sudom|lya (18B1), Udom|lya (40G3), Zdym |lya (18V3); others - Gorodom|lya (isle) (54V2), Sudom|lya (marsh) (18B1).

$(*)$ Oikonyms which are derived from hydronyms. 


\section{Stems of hydronyms based on anthroponyms}

Many of the stems connected with the formant -lya can be derived from old Slavic anthroponyms, e.g. Chuchem $\mid$ lya $<$ Chucha (Ahlqvist 2006: 19 referring to Veselovskiy 1974 ) < Russ. dial. чуча 'aboriginal' (Dal IV 616), cf. Chude, Khotim $\mid$ lya $<$ Хотимь (Vasilyev 2005: 182, 186, 249), Sиdom|lya < Судомирь, Судислав (ibid. 2005: 323), Tukhom|lya < Тухом (ibid. 2005: 246, 249), Tushem|lya < Tyшем (ibid. 2005: 246), Lyutiv|lya, Lyutom|lya < Лють (ibid. 2005: 41, 271), Radob|lya < Радомь (ibid. 2005: 68, 249), Zhelom |lya < Желе|гость (ibid. 2005: 141). Stems of some names can be derived from such Russian words which can be used to reconstruct anthroponyms: Retom|lya ?< ретивный 'furious' (Dal IV 93), Dremov|lya ?<дрема 'dream, doze' (Dal I 491), Kokh|lya ?< Russ. Smolensk кoxamb 'to love' (Dal II 180).

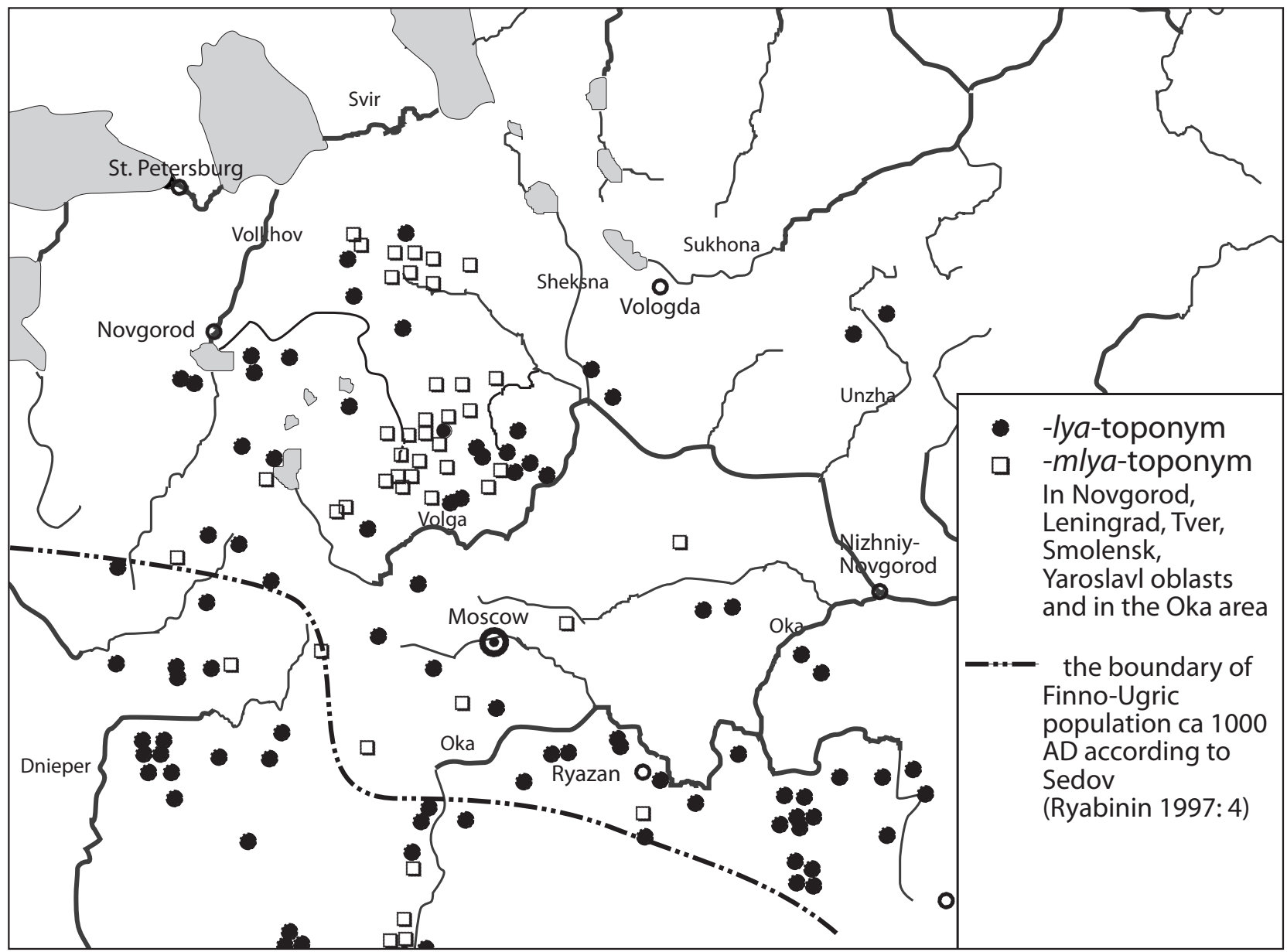

Map 7.The areal distribution of toponyms with the formants -lya and -(V)mlya. 


\section{Stems of hydronyms based on old dialectal Russian words}

Some of the toponyms are based on old Russian (often dialectal) words that are usually related to obsolete cultural customs: Khatom lya $<$ Russian [South \& West] xama 'cottage' (Dal IV 543), Sukrom|lya < Russian [Novgorod/Pskov] сукром 'store for food, etc.' (Dal IV 359), Tsynov|lya < Russian изыновать 'peel bark off bast' (Dal IV 575), Posokh lya < Russian nocox 'traveller's staff' (Dal III 339), Zdym $\mid$ lya $<$ Russian [Pskov] здымм 'lifting of an object' (Dal I 676).

\section{Finno-Ugrian specifics}

Some of the -lya toponyms have Finno-Ugrian specifics. For example, in the vicinity of Novgorod there is Tuleb|lya $<$ *Tulem|lya literary '(on)coming river' and Yaim|lya 'needle river'. In the ancient area of Mordovia area there is Kev|lya (GBO256) 'stone river', Shuzh|lya (GBO250) 'oats river' and Osh|lya (GBO253) ?<*Ash|lya 'white river'. In the Mordovian names the formant -lya certainly has the same original form and meaning as Mordvin läj 'river'.

\section{Unknown stems of hydronyms}

Some of the specifics of lya-toponyms remain difficult to explain. These include Itom|lya, Korkom|lya, Pyardom|lya, Karm|lya, Oskom|lya and Kasp|lya. The last is a large tributary of the River Daugava (Zap. Dvina) flowing in Smolensk oblast that could be derived from the Baltic languages; cf. Lith. kaspinas 'ribbon' (LAŽ 1985: 167). The others may originate from Chudian anthroponyms (see below).

\section{Etymology of the formant -lya}

Because it is possible to connect this formant with Russian as as well as Finno-Ugrian stems of toponyms, and possibly even with Baltic ones, it is very difficult to define the original source language, if there really is only one etymological origin. The distribution map (Map 7) shows that the formant -lya does not occur in the historically known Finnic territory of the Veps and not widely in the territory of the Meryans of the chronicles. According to the distribution map, it is possible to assume that possibly the early Slavs adopted from the ancient western Mordvins or from their cognate tribes the appellative läj < *läkä 'valley, river' (a modern Russian counterpart may be овраг [с речкой] 'valley where a river flows'). Phonetically Proto-Finno-Volgaic *läkä is possible, with $* k>j$ (Janne Saarikivi, personal information; Bartens 1999: 38; Lehtiranta 2001: 68).

If the origin is not Finno-Ugrian, in the background there may be a word that occurred already in the Balto-Slavic proto-language; cf. Proto-Slavic *lëjo 'flow', Lithuanian lieju (ESRJ III 504). There exists also in Latvian the word lej|a 'valley, lower-' (Pajula et al. 1997: 110) which could be the origin of the formant. Thus, 
a Balto-Slavic or Baltic origin is a possibility. A Slavic origin seems unlikely because of the narrow distribution of the formant -lya in the Slavic-speaking area.

Krysko (2006: 225) reports that in Russian, connected with persons, there sometimes occurs a possessive element $*_{-j}(\mathrm{~b})$. This element is preceded by $\langle\pi>$ after the labial consonants $\sigma, в, n$ and $\phi$; е.g. Ярослав|ль, епископ|ль, философ|ль. However, this does not occur with the endings - ов/-eв, so such a type as Pocmoв|ль is not possible. Krysko does not present any examples with the labial consonant $<_{\mathcal{M}}>$, but supposedly there exist such cases; cf. in verbal conjugation uуметь : шум|л|ю. In many cases the formant -lya occurs expressly after the labial $\langle m\rangle$. The formant -lya could, in principle, originate from this phenomenon, but in that case it would be difficult to explain such names of rivers as Kokh|lya in Smolensk oblast (ASO34B3) or Rod|lya in Kostroma oblast (AKO34B3) and numerous others. In addition, there exist several -lya-toponyms that are not based on persons or their names. There are good reasons to note Jouni Vaahtera's view that there do not exist such dialectic factors inside of the Russian language that could explain the areal distribution of the formant in question. Instead, he considers it to be caused by a substrate (Vaahtera: e-mail 8.9.2010). This formant does not occur in the area of the westernmost dialects in the Pskov region or in the River Shelon area, but it occurs in Novgorod oblast east of Lake Ilmen (see Map 7).

\section{Formant -om-/-emlya}

Among 54 -lya-toponyms that I have collected from maps, there are 27 toponyms with the element -om-/-em- (see Map 7). In most cases it is difficult to believe that all of them could originate from shortened anthroponyms with original -mir endings, such as Vido $\mid$ mir $>$ Vidom. Therefore, I presume with reservations that the element $-m$ at least in some cases is an original Finno-Ugrian genitive marker $*_{n}>m$. The variation of $m \sim n$ is common in Russian (e.g. Ahlqvist 1999: 627-629). There are such variations also in -lya-toponyms in the Oka watersystem: Rado|m|lya (GBO18,25,224) vs. Rado|n|lya (GBO32). Genitive constructions are very common in toponyms whose stem is based on personal names. The fact that toponyms with $-m \mid l y a$ do not occur in anywhere in Smolensk oblast but the northern parts (see Map 7) suggests a FinnoUgrian origin. The boundary of these toponyms follows that of Sedov's (Ryabinin 1997: 4, map 1) and Kriiska \& Tvauri's illustrations of the ancient Finno-Ugrian settlement (see Maps 2 and 7). In Vologda and Kostroma oblasts there exist two interesting hydronyms connected with this problem. South of the Lake Belozero there occurs Rodo $|m|$ boy (AVO53B5), while in the headwaters of the Unzha there is a river Rod lya (AVO83G5) that may be based on the anthroponym Poдb [Rod'] (Vasilyev 2005: 254). An appellative boy occurs in the hydronyms of the Sheksna-Belozero region. Saarikivi (2004: 200-201) has interpreted it as derived from PU *woja (> Finnish oja) 'streamlet', and in that case the translation of Rodom|boy could be 'Rodo's streamlet'. Rodlya should be translated 'Rod-streamlet'. 
There exists a corresponding Russian genitive construction among the toponyms of Tver oblast. For example, we find Drem $\mid$ ov lya (ATO201B3) in which Dremov seems to be a personal name, and the translation is thus 'Drema's river'. The possessive structure with the sign -ль mentioned by Krysko (see above) expressly does not work on names with $-e v /-o v$ such as Kiev or Rostov, because -ov or -ev are already genitive markers. This seems to assure that the formant -lya does not originate from this Russian genitive structure.

The name of an island in Tver oblast in the Lake Seliger ( $<*$ Seriger), Gorodom $\mid$ lya (ANO117B1), may offer proof for this presumed Finno-Ugrian genitive in $m\left(<*_{n}\right)$. The island is situated before the town of Ostashkov. Earlier there was also a town nearby called Zhabachev, which belonged to the princes of Smolensk. The town is mentioned in an ancient (from 1150 AD) document Ustavnaya gramota (Isakov 1985: 66). The stem of the name of the island is clearly derived from the Russian word gorod 'town (fortified)'. The form gorod $\mid$ om might be a Chudian genitive *gorodo $\mid n$ 'of the town'. In the middle of the island there exists a long and narrow lake that could be the reason for the formant -lya. On the other hand it is possible that the original meaning 'valley, river' of the formant was obscured and later it could be attached to all kinds of toponyms.

It is probable that the Novgorodian Chudes adopted Slavic Christian personal names, adapting them to their own language in the same way as e.g. Karelians have done. Oikonyms later arose from these just as in Finland; cf. the Russian anthroponym Hacmacья > Karelian Nasto > oikonym Nasto $\mid$ la or the Russian anthroponym Прокопий > Karelian Kuоріo > oikonyms Kuopio|la, Kuopio (SP 195, 286). On these grounds it is possible that among the Novgorodian Chudes there occurred such shortened personal names of Slavic origin as Rado $>$ hydronym Radom|lya 'Rado's river', Sudo > hydronym Sudom|lya 'Sudo's river', Niko > hydronym Nikom lya 'Niko's river', etc. Original Chudian personal names could be Ita, Korka, Oska, Pärda, Uda, Shada. ${ }^{21}$ They occur as stems in several -omlya hydronyms. Their correspondences are e.g. in the Middle Volkhov Osk|uya 'Osko streamlet' (ANO14B2), in the Svir water system in the upper courses of the Yavosma Pyardomskoye oz. Veps. Perdomjärv (close to a village called Chudskoye), in the Oka area Perde|ley (GBO269) and Perd|ino oz. (GBO124), Shadym|ka (GBO256), Itja (GBO173). There exists an anthroponym Uda in Novgorodian birchbark documents that has been interpreted as Finno-Ugrian (Saarikivi 2007: 226-227) > Udomlya. It is possible that the second vowel which is represented by $o$ in Russian was originally a reduced vowel $\partial$, i.e. $U d a$ : $U d \partial n>U d o m$. Except for the last, all other -lya-hydronyms are relatively small waters that could be considered as usufructuary rights of individual persons or families offering good grounds for naming.

Undoubtedly, there are also toponyms that truly are shortened forms of old Slavic anthroponyms with -mir $\left(*_{-}\right.$mir $\left.>-m\right)$. The river Tukhom|lya in the upper courses of

21 Perd-/Pärd-anthroponyms and hydronyms may be derived from an original Indo-European *pertä 'wing' Udm. burd (Koivulehto 2006: 183). 
the River Lovat serves as an example. A village called Tukhom|ichi is located close to the river. This type of naming by adding -ichi belongs typically to the old Russian tradition. The construction consists of a personal name Tukhom + Russian formant -ichi (Vasilyev 2005: 246, 249; Mullonen 2002: 84-105).

$-z h a(-\varkappa a)^{22}$

This formant occurs throughout Novgorod oblast and is connected with rivers. It occurs in a large area also elsewhere in Northern and Central Russia. Matveyev (2004: $21)$ considers it probably a diminutive marker. I personally agree with him and consider $-z h(V)$ to be derived from diminutive. The sibilant $<z h>$ of formants can possibly be a Russian substitute for Chudian voiced $* \check{\zeta} \sim$ Proto-Finnic diminutive $*_{-} \check{c} \check{c} u$ (Saarikivi 2006b: 32).

$-s h a,-k s h a,-k s a(-m a,-\kappa m a,-\kappa c a)^{23}$

It seems that $-s h(a)$ has the variants $-k s a /-k s h a$. This formant with both variants occurs widely in Yaroslavl and Vladimir oblasts: Volo $\mid k s h a \sim$ Volo $\mid$ sh $\mid k a(\mathrm{GBO} 196)$ $<{ }^{*}$ Volo $\mid$ ša, Shumo $\mid k s h a \sim$ Shumo $\mid$ sh (GBO126), Kolo|ksha $(\mathrm{GBO} 210) \sim$ Kolo $\mid$ sha (GBO218), Tome $|k s h a \sim T o m u| s h \mid k a(\mathrm{GBO} 212)<*$ Tomə|ša.

However, the formant $k s a-/ k s h a$ does not occur in the area of the Moscow-centric Dyakovo culture, where only -sh(a) formants occur: Lav|sha (GBO106), Nero|sh|ka (GBO41) < *Nero|řa, Pono|sha (GBO105), Tol|sha (GBO142), Ugre|sha (GBO88), etc. This fact suggests that the more widespread $-\operatorname{sh}(a)$ is older than the more narrowly spread -ksal-ksha. This also accords with what Ahlqvist (2004: 12) has presented.

However, there is a difficulty in dating the formant in question. Scholars have usually considered a reverse development, $* k s>s$, according to the history of the declensions of Finno-Ugrian nouns; e.g. Finn. vari|s : vari|ks|en [crow : crow's] (cf. Mullonen 2002: 217-222), where the declined form $-k s$ - has been understood to be older. But, as it was presented above, the evidence of the areal distribution seems to contradict this hypothesis.

Matveyev has connected the formant $-s h(a)$ with $-z h(a)$ (Matveyev 2001). The variants of formants $-s h a \sim-k s h a$, however, stand against his assumption. In my opinion $-z h(a)$ is of different origin, a diminutive marker as presented above. Both Ahlqvist and Matveyev claim that the formant - $g d a /-k h t a$ could be derived from an earlier formant -ksa/-ksha (Matveyev 2004: 27-28; Ahlqvist 2004: 11-13). The following variants of the same hydronym prove that a development $*_{-k \check{s} a}>*_{-k c} a>-g d a /-k h t a$ has taken place: Molo|ksha Molo|khcha $\sim$ Molo|khta (GBO 201).

22 In Novgorod oblast: Kobo|zha (ANO28A3), Kobo|zha (ANO30A2), Molog|zha (ANO25V5), Orede|zh (ANO20B1), Rabe|zha (ANO47V5), Sere|zha (ANO55A3), Vereg|zha (ANO33A5), Volo|zha (ANO34V4), Volo $|z h| b a(\mathrm{ANO} 17 \mathrm{~A} 5)$, Voro $|z h| b a(\mathrm{ANO} 41 \mathrm{G} 4)$.

23 In Novgorod oblast: Yere $\mid$ sha (ANO21B5), Kolo $\mid$ sh $\mid k a$ (ANO32V2) < *Kolo $\mid$ sha, Nurdy $\mid$ sha (ANO33B5), Ragu|sha (ANO17B5), Shildu|sh|ka (ANO25B4) <*Shildu|sha, Mene $\mid k s h a(A N O 14 V 2)$, Nudo|ksa (LPNP:K6/N). 
$-s t^{\prime}(-c m b)$

The Novgorodian hydronym Kerest' (ANO14V2) has a correspondence Kerost' (AJO110A1) in Yaroslavl oblast. In Central Russia, especially in the Meryan-Muroma territory defined by Russian chronicles, there occur also other hydronyms which have a formant -st'/-sta: in the Klyazma region Lakho|st'(GBO219), in the Oka area Nere|sta (GBO137), Uro|sta (GBO261), Vob|sta (GBO39), in Yaroslavl oblast Sulo|st' [a settlement] (AJO102), Shigolo|st'(AJO80) and in Kostroma oblast Yakhru|st (TKKO36). The formant in question may have a common origin with the Finnic derivational suffix $*_{-s t}(V)$ (Finn. -sto/-stö, Est. -ste, Veps - $\left.(i) \check{s} t\right)$.

The stem $\operatorname{Ker}(V)$ - is very common in what the chronicles call Meryan territory: Kero|st'(AJO110), Kero|ma (AJO17), Kera (AKO182), Ker|bash (AKO138), Ker|na (AKO133), Ker|nas (AKO160), Kera (GBO234). In the Finnic area there are numerous toponyms with the specific Keri- < keri|tä 'shear', but the verb is derived from Germanic *skeran, which is very unlikely to be connected with Central Russian toponyms. The correspondence between Kerest' [Chudovo, Volkhov] and Kerost' [Rostov, Upper Volga] links this hydronym and the formant clearly with the Upper-Volgaic connection.

\section{$-(y) e r(-e p)^{24}$}

The formant -er -eŕr -ero/-oro connected with lakes occurs quite widely in Central Russia and has the same etymology as Mordvin erke/järkä and Mari jer/jär. (Ahlqvist 1997: 29; 1998a: 42; 2000: 16-18; 2004: 15; 2006: 12, 17-20; Matveyev 2001: 290292.) The formant originating from shortened form -aŕl-är 'lake' that occurs only in a rather narrow area in the eastern Veps territory, namely the upper courses of the River Oyat (MAG), is not necessarily connected with the Novgorodian Chudes because of the areal narrowness of its distribution.

The etymology of the Finnish word järvi 'lake' that Rédei gives, deriving it from the Proto-Finno-Volgaic *järwä (UEW II 633) should be reconsidered, because the word occurring in the Meryan hydronyms яxpa $<*$ jä $\gamma r a / \ddot{a}$ cannot be derived from the root presented by Rédei. The solution could be an early metathesis $*_{-} k r>*_{-} r k$. Some scholars have derived the word from a Baltic original; cf. Lith. jáura 'bog' $<$ Proto-Indo-European *euer- (Nuutinen 1989: 497-501). This solution too seems impossible if one bears in mind the Meryan word *jäyra/ä. Arja Ahlqvist has studied the problem of Nuutinen's presentation (2006: 20, footnote 13) having critics against his solution as well. Saarikivi (2006b: 35 ) also suggests a proto-word with $*-k r-$. IndoEuropean linguists such as R. Beekes, however, have reconstructed the PIE word as *ieuHr- (Mallory \& Adams 1997: 636). The assumption of a laryngeal in the IndoEuropean proto-language might explain the reason for the metathesis $*_{-} k r->*_{-} r k$ - I suggested above, because ${ }^{*}-H r->-k r$ - should have been more unnatural for speakers

24 In Novgorod oblast: oz. Ilmen < *Ilm|er (ANO34B2), Lam|er|skoye oz. (ANO36B3), Nev|ery oz. (ANO46B3), Never|ka (ANO 46B3), Selig|er oz. < Serig|er (ANO54V2). 
of Finno-Ugrian languages than -rk-. Proto-Uralic had liquid+plosive combinations, but plosive+liquid combinations were very rare (Petri Kallio, personal comment).

Proto-Saami *jāvrē; Meryan *jäyralä and the *jädralä that occurs in the territory of the Novgorodian Chudes (see the formant -dra below) can be derived without difficulty from the root *jäkralä. Finnic *järve, Mordvin E erke M (j)ärkä and Mari jer/jär can be derived from *järkä. In that case, the -kä of Mordvin jär $\mid k \ddot{a}$ is not a diminutive marker as usually has been thought (SSA I 259), but part of the original stem. The element $-i$ of the second syllable in Finnic (note the exception of Livonian) offers a good reason to suspect the regularity of the whole second syllable

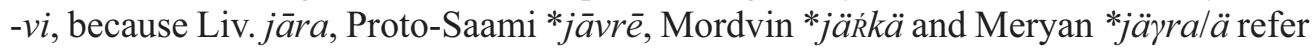
to the historical vowel *a/ä in the second syllable. ${ }^{25}$ The Estonian dialectal word järi is declined in the genitive as järve (EEW 603) proving that it is a shortened version of the word *järve and does not represent an independent development from the original root of the proto-language.

These two lines of linguistic history are visible in the 'lake'-hydronyms of Novgorod oblast where both jer (jär) $<*$ järkalä and *jädralä $<$ *jäkralä hydronyms or formants based on them occur Map 8). For example the component -er of the lake *Ilmer might be developed as the following: *järkä $>*_{j a ̈ r} \gamma>*_{j} \ddot{r} r$. The last stage *järi is supported by the name of the River Yary|nya [Яры|ня] (ANO36V3), -nya being a typical Russian formant. The Lake Lam|er|skoye (ANO36) is the source of this river. The specific of the river could thus be *järi 'lake'> Yarynya 'lake river'. In Valday exists the Lake Nev|ery (ANO46); - ery? < *järi. Close to the town of Velikiy Novgorod flows the River Yere|sha (ANO21B5), whose original form may be *Järi|š. The river has its sources in a bog where a lake called Goriyskoye oz. is located.

The stems of -er/-or-lakes in Novgorod (ANO) and Tver (ATO) oblasts have several correspondences with the names of rivers in the Upper Volga (AJO) and Oka regions (GBO): *Ilm|er (ANO34) vs. Il'ma (AJO109), Il'mezh (AJO36), Il'menka (AJO112), Lam|er|skoye oz. (ANO36) vs. Lam'(AJO27), Lamo (GBO220), Lamekh (GBO223), Lamenka (GBO224), Lam|ka (GBO246), Pud|oro (ATO54A4) vs. Pudega (AVO76), *Serig|er ANO54 vs. Seruksha (AJO115), Serenga (GBO147), Seroksha (GBO210,212), Tam|or|zha (ATO54B1) vs. Tamara (AJO102), Tum|er|to (ATO256B2) vs. Tumash (AJO98), Nev|ery ANO46) vs. Nev|ra (GBO223), Nev|ley (GBO242,264), Neva (GBO185). ${ }^{26}$ Thus, it is not possible to connect the word *järi of the hydronyms in Novgorod and Tver oblasts with the Estonian word järi $<*$ järve.

25 Sometimes an original $* k / g$ can be represented in open syllables in loanwords in Finnic as $v$; e.g. porvari $<$ Late Old Swedish borghare (SSA II 402) offering the phonetic possibility of *jär $\gamma(V)>$ järv $(V)$. 26 It is unlikely that the stem * serig is derived from a fish *serig 'roach' as suggested by Mullonen (2002: 235), because in Finland Särki|järvi 'roach lake' was never the name of any big lake (GT2000:

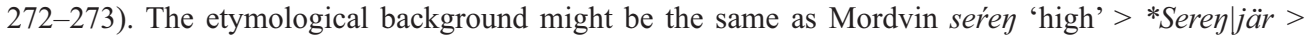
*Seriger 'high lake' (MW IV 1970). Lake Seliger is located in the Valday highlands, being the highest lake in the Volga catchment area. 
$-d r a(-\partial p a)^{27}$

The fact that in some ancient language in Novgorod and Tver oblasts there has been a word *jädral ä can be concluded from -dra-formants that almost without exception are lakes or rivers connected with lakes (see the list in footnote 27). In addition, in Valday there occur such names of lakes as Yedr|ovo oz. (ATO50A1) and Yedr|itsa oz. (ATO32A3). In the upper courses of the River Daugava occurs the Lake Edr|itsa oz. (ATO50A1). Some -dra-formants are found also in the Svir region Kuz|dra (MAG2), in Yaroslavl oblast Savo|dra|nka (AJO67A1) and, on the boundaries of Vologda and Yaroslavl oblast Yashkon|dra (AJO22B1).

I present as an explanation for two different words for 'lake', *järi and *jädralä, the following hypothesis with reservations. In Novgorod and Tver oblasts there may have been two kinds of Chudes, "western" and "eastern" (Map 8). In the area of more western Chudes, mostly on the south-western side of the River Msta, there occur e.g. the words *m(u)sta 'black' (Map 5) and *järi 'lake'. However, in both of these languages the phonetic shifts typical for the Finnic languages had not taken place; $* \check{s}$ $>h$ and $*_{\check{c}}>t$ (see below Section 6). It is possible to think that the language of "the western Chudes" (WCh) was phonetically close to Proto-Finnic or the Proto-FinnoVolgaic language. On the other hand there seem to be some words which are close to Mordvin: WCh čere $\sim$ Mordv. čire 'being alongside', WCh lama $\sim$ Mordv. lamo/ lama 'much/big' (see hydronyms above), WCh tum $(V) \sim$ Mordv. tumo/tuma 'oak' (see hydronyms above), and possibly the word vel- 'upper'. There are such small headwaters as the River Vel'giya ? < Veljog $(V)$ 'upper river' (ANO39A4) and some others with the stem vel-. Many of them are so small that it seems difficult to derive them from the Slavic stem вел- 'big'. In the present article it is not possible to enter more deeply into this subject.

The language of the "eastern Chudes" (ECh) seems to have had some similarities with the language spoken in the territory of the Merya of the old Russian chronicles; cf. ECh $j \ddot{a} d r a / \ddot{a} \sim$ Meryan ${ }^{*}$ jä $\gamma r a / \ddot{a}\left[{ }^{*} g>d\right]$. There are also indications of a common word $\operatorname{vol}(o)<$ Finno-Volgaic *ala 'lower' in ECh and Meryan (see also Rahkonen 2009: 172). Thus the following two matters in the "ECh language" share common features with the language spoken in the Meryan territory and Saami: 1) the common historical root *jäkrä 'lake' and 2) the phonetic shift of initial $* a>v o$. It is important to emphasize that the boundaries were not very strict. Ancient Finno-Ugrian tribes did not establish any national kingdoms with clear boundaries.

27 In Novgorod oblast Keza|dra oz. (ANO41V3), Lima|ndr|ovo oz. (ANO39A5), Limandrovka (ANO39A5), Nez|dr|inskoye oz. (ANO25G3), Shabo|dro oz. (ANO40B1), Shabo|der|ka (ANO40B1), Sherego|dra oz. (ANO27B4), Tikhoman $\mid$ dr|ica (ANO40V3), Tishi|dra oz. (ATO54A3). 


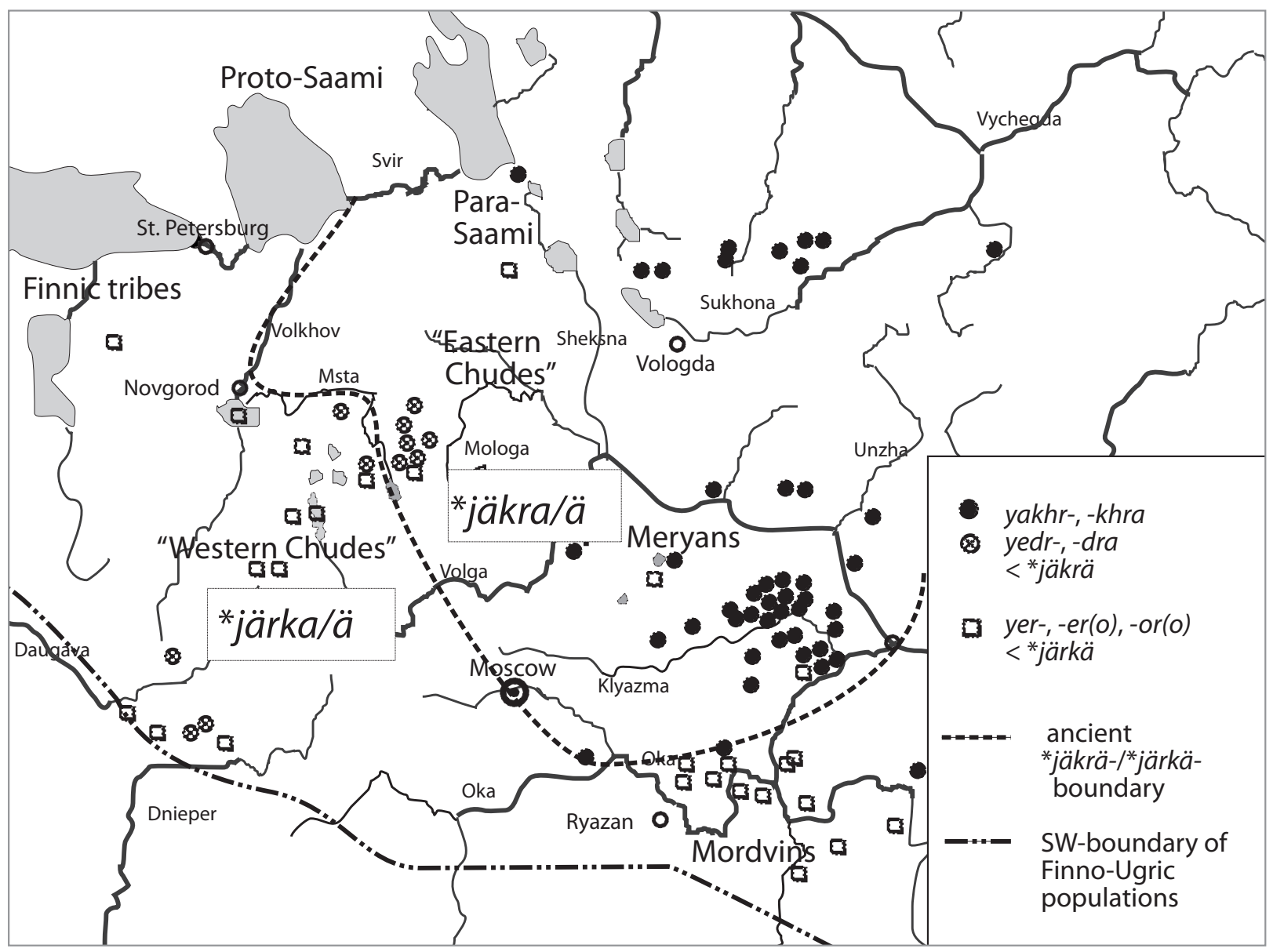

Map 8. Yakhr-, -khra, yedr-, -dra and yer-/yar, -er(o), -or(o) names of lakes in Central and North Russia and the possible boundary of the proto-language words *jäkralä and *järkalä.

- uуa $(-y я)^{28}$

Undoubtedly, this formant is derived from the Finnic word oja 'ditch, river' (see Matveyev 2001: 256-261). The specific Osk- may be a result of a metathesis oska < *oksa 'twig' or *oksi 'bear'. An origin in a personal name Oska is possible, even probable; see above the formant -lya, Oskom|lya (ATO94A4) and Oskom|lya ruchey (ATO123A1). Oskuya is located close to the boundary of the area of Finnic hydronyms (see Section 4, Map 4).

$-n d a(-H \partial a)^{29}$

The formant -nda has correspondences in Finnic toponyms (cf. in Finland Vesa|nto, Pyhä|ntä), but also in the Oka and Upper Volga region; cf. Ile |nda(GBO228), Leve|nda (GBO193), Uro|nda (GBO216), Shura|nda (GBO252), Bol. \& Mal. Kolo|nda (TKKO21), Meze|nda (TKKO21). The majority of these are located in Kostroma and Vladimir oblasts. The same formant also occurs in the region of southern Lake Onega

28 In Novgorod oblast: Osk|uya (ANO14B2), Osk|uy|skoye oz. (ANO14B3)

29 In Novgorod oblast: Vero|nda (ANO33A5) 
and the River Svir: Luzha|nd|ozero (AVO12), Sula|nd|ozero (AVO12), Vera $\mid$ nda (MAG2), Yulo|nda (MAG18), Sura|nda (MAG13), Viksi|nda (TKRK116) (see also Mullonen 2002: 199, 290-292).

Ahlqvist (1992: 27-28) has pointed out that the formant -nda varies in central Russian toponyms with the formant $-n g a$. Such $n k \sim n t$ variation is found also in Finnish dialects: e.g. *nki > nti; cf. *kaupu|nki> kaupu|nti 'town' (SSA I 332). Finnish toponyms also display the variation *nti $>n k i$; cf. *Anu $\mid n t i>A n u n k i$, *Holla $\mid n t i>$ Holla|nki, *Muola|nti > Muola|nki (Räisänen 2003: 15, 21-22, 80-81).

The River Veronda (ANO33A5), close to Velikiy Novgorod, has a counterpart in the river Vera|nda $\sim$ Vere $\mid n d a$ and the lake Vera|nd|ozero (MAG2) in the Upper Svir. Direct Finnic counterparts, such as *Vierunta are not found in Finnish toponyms (NA), but the lakes Vierus|järvi (GT2000: 156C2) and Vieruva|n|järvi (GT2000: 47F1) may correspond. In the Oka region as well as in Yaroslavl and Kostroma oblasts there occur the probable correspondences Ver|da (GBO179,185), Vere|pa ?< *Vere|upa (GBO160), Vere|sh|ka <*Vere|ša (GBO41), Ver|zha (GBO210), Ver|kusha (GBO152), Vere|ksa (AJO57), Ver|bush|ka (AKO186), Vere|me|evka < *Vere|ma (AKO173), Vere|na (AKO197), Ver|zhe|nka<*Ver|ža (AKO184). The stem ver(e)can be compared with Mordvin word ver'/vär' 'upper' that, on the grounds of the areal distribution of this specific, seems to have belonged to the language of the Meryans of the chronicles as well.

\section{Conclusions}

The Finno-Ugrian formants of Novgorod oblast can be viewed as five groups: 1) the Oka-Upper-Volgaic group, 2) the vast Finno-Ugrian group, 3) the Finnic group, 4) the local group and 5) the Finnic-Upper-Volgaic group. Many of these groups have connections with toponyms in Northern Russia, but because the toponyms there are very heterogeneous, Northern Russia has not been considered as its own group.

The Oka-Upper-Volgaic group contains the formants -ra, -lya and -er. The vast Finno-Ugrian group contains the formants -sha/-ksa/-ksha, -zha, -ma/-ba, -ga. The Finnic group has only the one representative -uya $<*$ oja. The local group is represented by formants with possible shift $*_{g}>d$; -oda $?<*$ joga, -dra $<*$ jädral $\ddot{a} ?<$

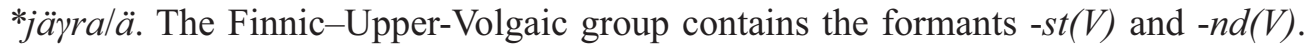
These two formants have representatives in the Oka-Upper-Volgaic as well as in the Finnic linguistic area. However, in Novgorod oblast they are rare. Only two hydronyms are known: Kere|st' [Chudovo] and Vero|nda [Velikiy Novgorod]. Otherwise they are strongly represented in the Oka-Upper-Volgaic territory. 


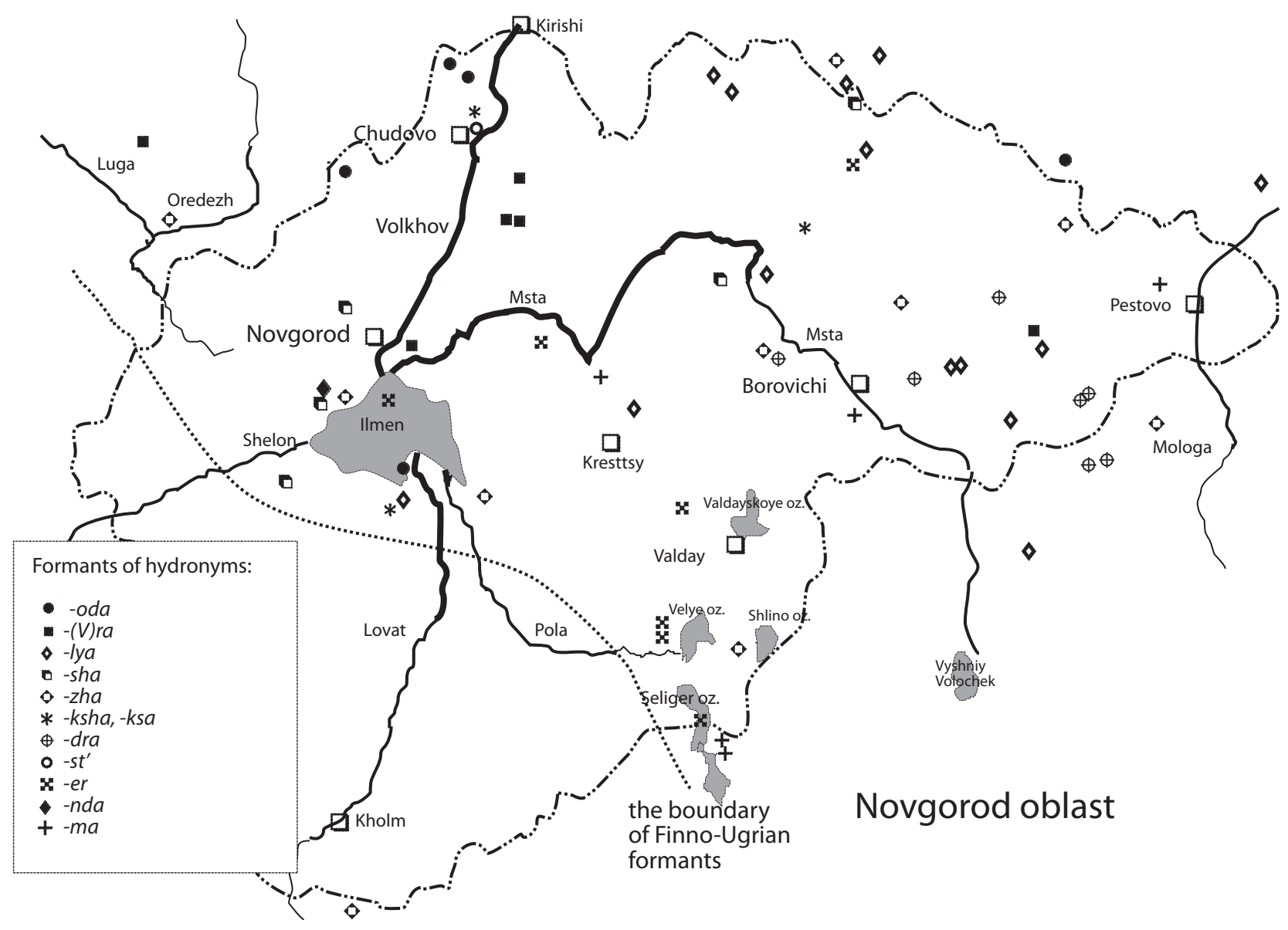

Map 9. Finno-Ugrian formants in Novgorod oblast.

\section{The Finnic sound shifts $*_{\breve{s}}>h, *_{\check{c}}>t$ and Novgorodian hydronyms}

One of the most essential sound shifts in Finnic is $*_{\breve{s}}>h$ and another is $*_{\check{c}}>t$ (Sammallahti 1999: 76; Kallio 2007: 233). For this reason it is very useful to examine names containing $\check{s}, \check{c}$ and $h$. With the help of these names it is possible to verify whether in the ancient language(s) of the research area the most typical Finnic sound shifts did or did not take place.

\section{I. Hydronyms with $\langle\check{s}\rangle$}

To this category belong such hydronyms as Shabo|dro oz. (ANO40B1) < * Šabo|jädra $<* \check{s} a b(V)$ 'aspen' || Shadomlya (ANO28G2) ?<*Šadonläj 'river of Šado' || Shuya $(\mathrm{ANO} 16 \mathrm{~V} 3)<*^{\prime}$ suj 'long bay into which usually empties a river' (the topography of *šuj-hydronyms in North and Central Russia mostly corresponds with this explanation) || Yashche|ra (LPNP: Ž $4 / S)<* J \ddot{a}(k) \check{s} \ddot{a} \mid r a<* j \ddot{a}(k) \check{s} \ddot{a}$ 'cold' (see SSA I 260) \| 
Bol. \& Mal. Vishe|ra (ANO14G2/23A6), Vishe|ra(ANO22V2), Bol. \& Mal. Visherka (ANO23B5) < *višelä 'viha-nta, vihreä' (see Sammallahti 1988: 554). Not far away we find another hydronym based on colours, the river Msta 'Black River'. These hydronyms have numerous correspondences in the Upper Volga and Oka region.

\subsection{Hydronyms with $\langle\check{c}\rangle$}

To this category belong such rivers and lakes as Chagoda (2) (ANO13A5; ANO19B5), Chagodoshcha (ANO6-7A8), Chagodskoye oz. (ANO34B2), Checho|ra(ANO28V2);

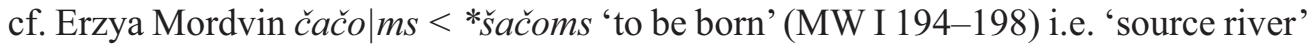
(this river is the last one in its catchment area) ${ }^{30}$, Cherma (LPNP:Z1/S) and the Lake Cheremenskoye < *Čerema; cf. Erzya Mordvin čire 'being alongside' (MW I 269); these waters are located parallel to a larger body of water. There are several correspondences in the Upper Volga and Oka regions.

On the basis of the hydronyms mentioned above, it is possible to conclude that some Finno-Ugrian language was spoken in Novgorod oblast and in the southern, south-western and eastern parts of Leningrad oblast that could not be Finnic, because the sound shifts $* \check{s}>\mathrm{h}$ and $* \check{c}>\mathrm{t}$ had not taken place. The hydronyms of the research area show a similarity with those in the Upper Volga and Oka regions. The stems *čer(e)- and *čeče- resemble the Erzya Mordvin words čire < *šere 'being alongside' and $\check{c} a c ̌ o|m s<* \check{s} a c ̌ o| m s$ 'to be born'. In that case, in the Chudian language there was a similar secondary $<\check{c}>$ as in Erzya Mordvin.

\subsection{Hydronyms with $\langle h\rangle$}

The initial Finnic $h$ can be substituted in Novgorodian Russian by the consonants $x, 2$ and $j-(я, e, \ddot{e}, \breve{u}, \wp)$ or by zero $\varnothing$ (Mullonen 2002: 51-56).

\subsection{Toponyms with initial Russian $k h-(x-)$ :}

Khaba|l|inka (ANO20B2), an oikonym in Leningrad oblast in the upper course of the River Oredezh. Undoubtedly, there exists in the background an Ingrian word hapa 'wood of aspen' (SSA I 126). The oikonym is located close to the historically known southern boundary of Ingrian settlement.

Khobo|l|ka (ANO51B4) is a river in the upper source of the River Lovat. The name can probably be derived from Karelian dialectal word [Valday] hoaba 'aspen' (KKS) (see Map 3), being connected with Käkisalmi Karelian refugees (Kirkinen

30 In the Meryan area occur widely $\operatorname{Shach}(V)$-hydronyms ? $<$ Meryan * šač $(V)$ - Mordvin čačo $\mid m s$, $\check{s} a \check{o} o \mid m s<\mathrm{PFP} *_{\text {še }}$ č-. 
1994: 154). The Finnic diphthongs are usually represented in Russian with the first vowel of the diphthong; cf. Suomi 'Finland'> Old Russian Сумь (ESRJ III 803).

Khuba (ANO23V6), Khub|ka (ANO23V5) are tributaries of the lower course of the River Msta. In the background there may the Tver Karelian dialectal word huaba 'aspen' (KKS). In the region in question, migration by the Käkisalmi Karelians has taken place (Kirkinen 1994: 154). In principle, it is possible to derive the toponyms also from the Finnic word hüvä 'good'. In that case the Finnic * $\ddot{u}>$ Russian $y$ and the Finnic $* v>$ Russian $\sigma$, which is possible according to the rules of adoption in the Novgorodian area (Mullonen 2002: 58, 68). The latter is more rare as a naming ground.

\subsubsection{Toponyms with initial Russian 2-}

Gebezhkoye oz. (ANO50A2) ?<*Hebož|järvi is a lake in the Lovat watersystem close to Khobolka. Phonetically it is possible to derive the specific from Tver-Valday Karelian hebo 'horse'.

\subsubsection{Toponyms with loss $(\varnothing)$ of the original initial Finnic $* h-$}

Izhina (ANO30B4) is a name of a river in the extreme eastern corner of Novgorod oblast close to the border of Vologda oblast. This hydronym can most probably be derived from an original *Hi(i)zi|na. In that case, in the background there may be the Salmi Karelian dialectal word hiž̌i 'demon, pagan worshipping place' (KKS). The river is not far away from the Vesyegonsk region where numerous Tver Karelians migrated in the 17th century (Kirkinen 1994: 166).

\subsubsection{Toponyms with $* h \sim$ Russian $\ddot{e}, \breve{u}, ю, я$}

Toponyms of this category are not found.

\subsection{Conclusion}

It seems that some toponyms with an initial $* h$ - exist in the research area. However, they can be derived either from Ingrian or Karelian migration in the 17th century AD. Even if they are connected with an earlier population, the number of these hydronyms is so small that most probably they are not inherited from the aboriginals of the Novgorodian territory, i.e. from the Chudes of the early Russian chronicles. At least the toponyms based on the diphthongs -oa- (hoaba) or -ua- (huaba) originate from the Karelian language. 


\section{Ethnonyms Chude and Nere Mere}

\section{I. $\operatorname{chud}(e)-$}

The area of toponyms with Chud(e) is vast. ${ }^{31}$ The areal distribution is focused in Novgorod, Leningrad and Tver oblasts. A total of 30 names have been collected here. Some stray occurrences are found in Moscow obl. (4), Yaroslavl obl. (4), Pskov obl. (3), Ivanov obl. (2), the Republic of Karelia (2), Smolensk obl. (2), Vladimir obl. (2), Kaluga obl. (1), Kirov obl. (1), Kostoma obl. (1), Tula obl. (1). Arkhangelsk oblast and the Republic of Komi are ruled out, because in these areas lived a tribe that was in the chronicles referred to as Zavolochkaya Ch(y)ude [Заволочкая Чюдь] 'the Chude behind the neck of land'. The connection of this tribe with the Novgorodian Chudes is not yet solved.

If the chud(e)-toponyms at least mainly reflect the ethnos of the Novgorodian Chudes mentioned in the Russian chronicles, the formation of the imperial governments of Novgorod and Tver seem to correspond to the core area of Chudian settlement quite well (Map 10). It is very important to note those areas where the number of chud(e)-toponyms is small or they do not exist at all. Even though the Veps are later called Chudes by Russians, the $\operatorname{chud}(e)$-toponyms do not occur in the historical Veps territory with the exception of the environs of Tikhvin and the name of the marsh Choudy|boloto (MAG53) in the area of the River Shoksha in the upper course of the River Oyat. Even more surprising is that in Vologda oblast, according to the atlas AVO (2008), chud(e)-toponyms are totally lacking. In the traditional Meryan territory in Yaroslavl, Vladimir and Kostroma oblasts the number is also low. A couple of chud(e)-hydronyms, Chud|ozero and Chudo|järvi occur in the Republic of Karelia in the Porajärvi region as well. These hydronyms may be of Saami origin reflecting hostile contacts reported in Saami folklore between a Saami population and Chudes (Grünthal 1997: 156).

31 Chudina (oikon.) (ANO48), Chudinovo (oikon.) (ANO43), Chudinskoye bol. (marsh) (ANO36), Chudintsevy Gorki (oikon.) (ANO32), Chudovka (river) (ANO24), Chudovo (town) (ANO13), Chudovo (oikon.) (ANO38), Chudsko (oikon.) (ANO32), Chudskoye oz. (lake) (ANO50), Chudskoye (nature) (ANO28), Chudskoy Bor (oikon.) (ANO13), Chudtsy (nature) (ANO16), Chudskoye ozero $\sim$ Peipus (lake) (LPNP:Z1/S), Chudskaya Rudnitsa (oikon.) (LPNP:I1/S), Chudskiye Zakhody (oikon.) (LPNP:I1/S), Chudtsy (oikon.) (LPNP:K7/N), Chudskaya (oikon.) (LPNP:I7/N), Opol'skiy v Chyudi (oikon.) (Ryabinin 1997: 18), Toldozhskiy v Chyudi (oikon.) ibid., Chudinka (oikon.) (AMO57), Chudinovo (oikon.) (AMO115), Chudtsevo (oikon.) (AMO37), Chudtsevskoye oz. (lake) (AMO37), Chudnovka (ATuO69), Chudnenkij (oikon.) (AKalO51), Chudinovo (nature) (ASO32,63), Chudino oz. (lake) (ARO68), Chudinovo (oikon.) (AVldO43), Chudskaya (oikon.) (AVldO65), Chud' (oikon.) (AIO18 AKO189), Chudinka (nature) (AJO21), Chudinovo (oikon.) (AJO38), Chudinovskoye bol. (marsh) (AJO61), Chudikha (oikon.) (AKO121), Chudal|ovo (oikon.) [Kir. obl.] (AVO67), Chudinka (oikon.) [Yrl obl.] (AVO92), Chudino (oikon.) (ATO67), Chudinovo (oikon.) (ATO134,152), Chudinovskiy (river) (ATO16,123), Chudiny (oikon.) (ATO96), Chudnikovo (oikon.) (ATO80), Chudovo (oikon.) (ATO189,211), Chudskoy Stan [Uglich] (Ryabinin 1997: 168), Choudy boloto (marsh) (MAG53), Chudojärvi (lake) (TKRK80), Chudozero (lake) (TKRK81). 


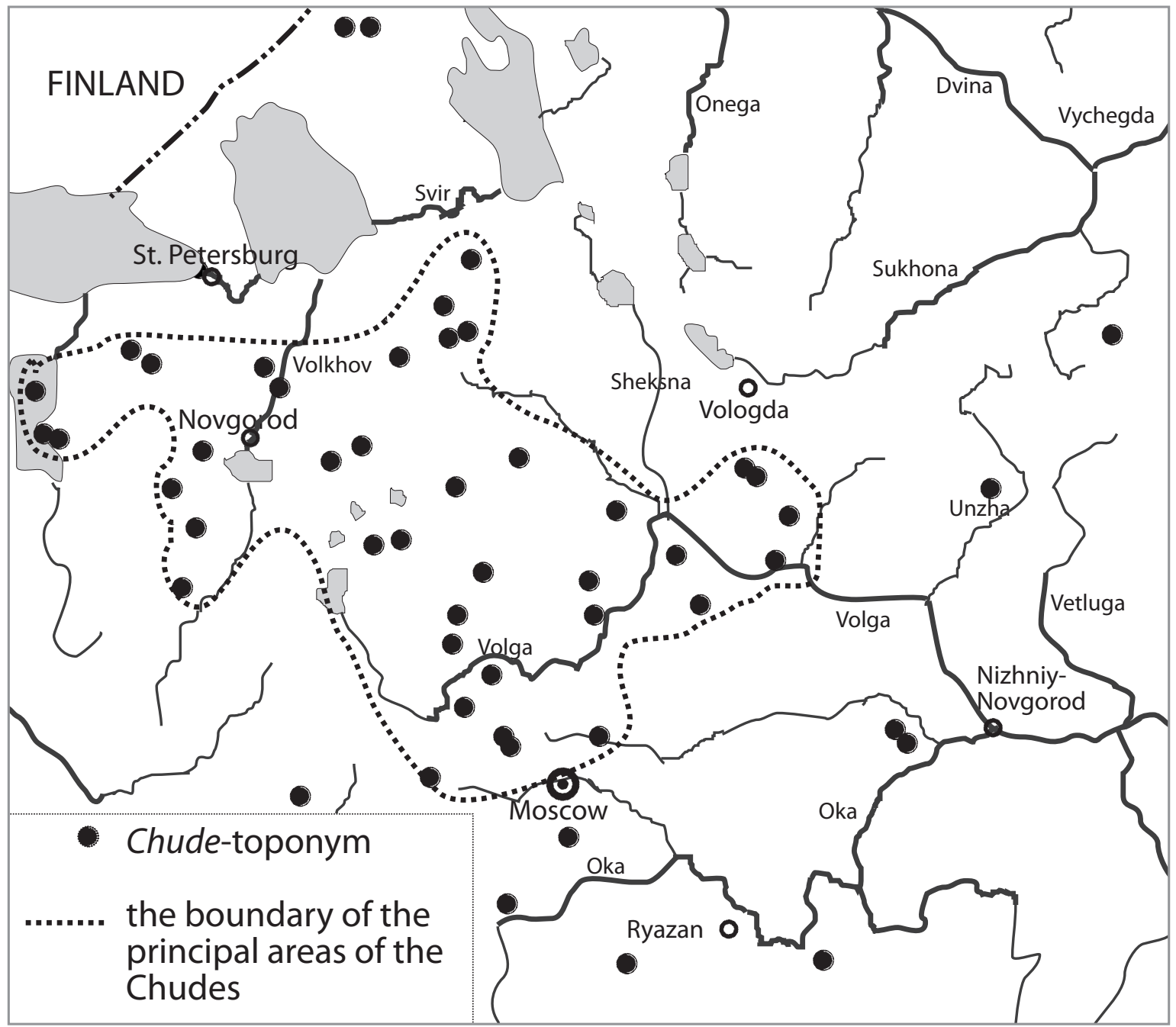

Map 10. The areal distribution of Chud(e)-toponyms.

There are some interesting stray toponyms. In Kirov oblast close to the border of Vologda oblast there occurs a village name Chudal|ovo. Close to it is another village called Chegado|evskiy. These names recall such toponyms as the town of Chudovo and the River Chagoda in the middle course of the River Volkhov. Thus, it seems obvious that these oikonyms in Kirov oblast have been transferred from the River Volkhov area. 


\section{2. $\operatorname{mer}(e)$, ner(e)-}

The majority of mere(e) and ner(e) toponyms are located in the traditional area of the Meryans and Muromas defined by the Russian chronicles. ${ }^{32}$ Merevskoye oz. on the border of Novgorod and Leningrad oblasts is hardly connected with actual Meryans, but more probably with an ethnos called Mereva Nereva (see Machinskiy 1986: 8-9). This ethnos is also known in the Povest vremennykh let in a literary form Neroma. It has been incorrectly interpreted as Narva (Cross \& Sherbowitz-Wetzor 1953).

The variants mer(e) ner(e) in the Upper Volga-Oka area seem both to refer to the Meryans of the chronicles. Ahlqvist (1999: 626-630) has seen a reason for the two variants in an $*_{n}>m$ shift in Old Russian; cf. *norrman $>$ murman 'Norwegian Viking'. In that case the original ethnonym should be *ner(e). Ahlqvist believes that it originates from the name of Lake Nero $<*$ In|jer. As a naming model her explanation is very reasonable, but there are still some problems left. If there is any connection with the ethnonyms Merya $<*$ Nere and Nereva $\sim$ Nereva $\sim$ Neroma of Pskov-Novgorod region, the explanation based on the hydronym Nero oz. is very unlikely. Already Herodotus (ca 485-420 BC) writes of a nationality called Neuri. According to him they lived somewhere "behind the Scythians" in the neighbourhood of the Androphags (?Mordvins). There are still mentions of them in Roman sources in the 4th century AD, placing this ethnos in the upper source of the River Dnieper. (Gimbutas 1963: 99-100).

I would present as one possibility that there was a Baltic tribe who came from either the River Narev (today in Northern Poland) or the River Neris (today in Belarus and Lithuania) and who migrated to the upper sources of the Dnieper and the KalugaMoscow area. The Slavs called them голядь ( Galindian). It is known that the western Galindians lived on the northern banks of the River Narev. In the upper sources of the River Daugava (Zap. Dvina) there flows a river Nar|yazykovo 'speaker of the Nar-language'. This hydronym can be connected with the Novgorodian Nerevas. It is possible that the Finno-Ugrians that are known as Meryans adopted the ethnonym from the neighbouring Balts.

32 Merevskoye oz. (ANO20), Mereley (GBO257), Mer|ka (GBO110), Mer|lyay (GBO240), Mer|ovka (GBO123), Mer|skaya (GBO110,129), Meryan|ovskoye (GBO205), Meryak|in (GBO272), Mer|skaya (AJO69), Mera (TKKO49), Merem|sha (TKKO41).

Ner|ach|ino oz. (ANO40), Nere|ts|koye oz. (ANO37), Ner|tsa (ANO37), Ner|ash (GBO209), Nere|vets (GBO262), Nere|vka (GBO261), Nere|vskoye (GBO124,141), Neres|l' (GBO208), Nere|sta (GBO137), Nere|khta (GBO227), Ner|l' [Klyazma] (GBO214), Nere|buzh|skoye (GBO221), Ner|ga (AJO72), Nere|khta (AJO85,95), Ner|l' [Volga] (AJO106), Nero oz. (AJO102), Nere|to (ATO21), Nere $\mid g$ (TKKO62), Nere |khta (TKKO45,50) || WRG: Nerizha Kr. Odoev, G. Tula, Nero|sh|ka Kr. Medyn, G. Kaluga, Nere|ta $\sim$ Narata Kr. Dvinsk, G. Vitebsk. Kr. = kray, G. = government. 


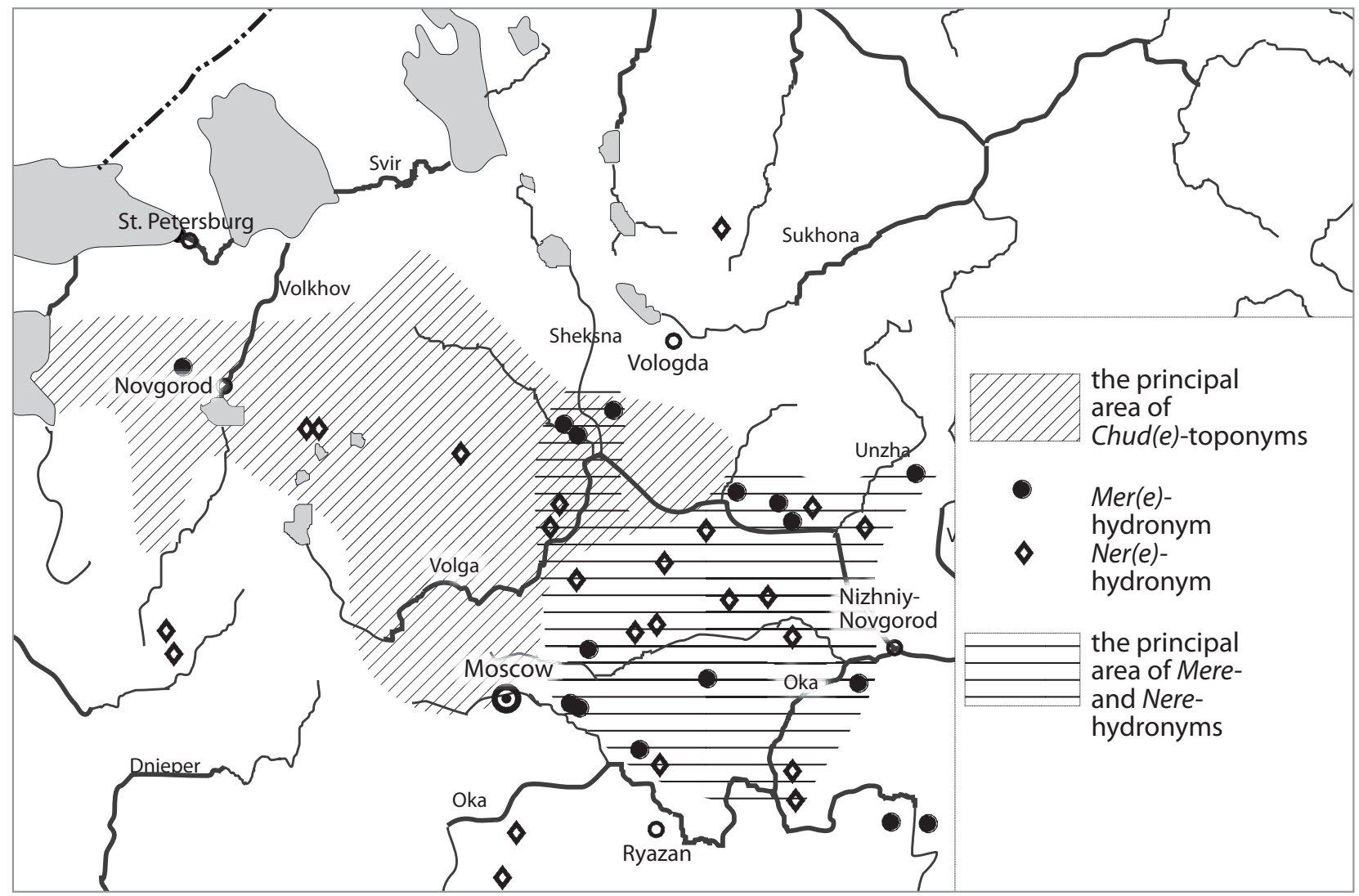

Map II. The principal areas of Chud(e), Mer(e) and Ner(e) hydronyms.

\subsection{Other ethnonyms}

There exist some other ethnonyms which are represented here only very briefly in the following list:

Kurlyandskoye (ANO45A4) < 'Kurlandic'

Libya (ANO47B4), Livitsa (ANO48A2) < 'Livonian'

Litvinovo (ANO36B2, ANO43V4) < 'Lithuanian'

Meshcherskaya Kromka (ANO35V5) < 'Meshchera'

Nemtsovo (ANO41B4) < 'German, Scandinavian' 


\section{Pskov region}

Neither Finnic nor Upper-Volgaic Finno-Ugrian macrotoponyms occur in the surroundings of the town of Pskov. The names of bigger rivers in this area are mostly Slavic, and therefore it is possible to presume that the Slavs have lived in the Pskov region for a long time. In the map Obzorno-Geograficheskaya karta (LPNP) 1: 400000 we find the following transparently Slavic hydronyms: Kamenka $<$ Russian камень 'stone', Shchepets < Russian щуеna 'chip', Velikaya < Russian великий 'big', Mnoga < Russian многа 'much; i.e. big', Shiritskoye oz. < Russian uир- 'broad', Chernaya $<$ Russian чёрный 'black', Belka < Russian бельй 'white' or белка 'squirrel', Velino oz. < Old Russian велий 'big', Brannoye oz. < Russian бранный 'battle, war-', Zabel'skoye oz. < Russian бельй 'white' and probably Slavic Zhel|tsa ?< Russian жёлтый 'yellow', Polon $\mid k a$ ?< Russian полон 'harvest, prey', Obdekh Estonian Optjogi ?< Slavic обьдо 'treasure', Lochkina ?< Russian лочига 'Lapsana communis', Uza ?< Russian yza 'beeswax'

In addition, there are etymologically obscure, possibly Old Baltic names such as Pskova < *Plbeskova; cf. a river in Lithuania Plisa (ESRJ III 397), Tolba $?<*$ tol $\mid$ upe; cf. Lith. tolimas, Latv. tāls 'remote', Lith./Latv. upe 'river'. In Smolensk oblast in the headwaters of the Daugava flows also the River Tolba (ASO84A2). The names of the rivers Keb' and Kebtsa could be of Finno-Ugrian origin, i.e. from Finnic *kive 'stone', but this interpretation has the problem of how to explain the vowel $\langle e\rangle$.

With the exception of the last two hydronyms, it is not possible to derive any of the larger hydronyms in Pskov region from Finnic languages. It is also noteworthy that the Russian name Chudskoye ozero ( Peipsijärvi $\sim$ Peipus) is not the name of the southern part of this double-lake, which is called Pskovskoye oz. The chud(e)toponyms as well as toponyms which are defined in this study as Oka-Volgaic reach only to the northern part of the lake; i.e. to the lake Chudskoye (see Map 1).

\section{Conclusions}

\subsection{Finnic toponyms}

As presented in Section 4, the southern boundary of transparently Finnic hydronyms runs from the north-east corner of Lake Peipus towards the region of Tikhvin, and thus in the lower courses of the rivers Luga and Volkhov indisputably Finnic hydronyms occur (Map 1). Their areal distribution is located mainly in the area of Leningrad oblast. In Novgorod oblast there occur only few hydronyms that are unquestionably Finnic. I have found approximately ten Finnic hydronyms in Novgorod oblast that can be classified as uncertain. Compared with the total number of hydronyms considered to be Finno-Ugrian, they are rather few even if they were all of Finnic origin. Taking into account that most of their stems or specifics occur also in the Upper Volga and Oka area, e.g. hydronyms with $I l$ ' $m$-, Kib- and Mst- (see Map 4) or that they have an 
Oka-Volgaic formant (e.g. Yaim|lya, Map 6), the Finnic origin of these hydronyms must be considered uncertain. The most remarkable argument against the Finnic origin of the Novgorodian Chudes is that there do not exist such Finnic specifics or generics in the hydronyms as for example in Arkhangelsk oblast.

The language behind the Novgorodian hydronyms has features in common with Finnic, especially in vowels. But one should remember that the vowels in Finnic are close to what is reconstructed for Proto-Uralic. As for the consonants, the sound shifts typical of Late Proto-Finnic had not taken place (see Section 6); $*_{s}>h$ (e.g. in the hydronyms Shuya, Shabo|dro oz., Yashchera, Vishera) and $*_{c}>t$ (in the hydronyms Chagoda, Chechora, Cherma, Cheremenskoye oz.). Toponyms with initial *h that could be considered as Finnic names in Novgorod oblast seem to originate from Karelian dialects; e.g. Khobo $\mid l^{\prime}<$ Ka.Valday hoaba and Khuba $<$ Ka.Tver huaba 'aspen'.

\subsection{Evidence of formants}

The following formants found in the toponyms of the research field occur in a vast area in Northern and Central Russia (see Section 5): -sha/-ksa/-ksha, -zha, -ga, -nda, $-r a,-l y a /-l$ ' and $-\operatorname{er}(o) /-o r(o)$. Some formants that originally probably were generics such as $-d r a<* j a ̈ d r a / \ddot{a}$ 'lake' and -oda $<$ *joga 'river' are typical especially in the areas of Novgorod and Tver oblasts and to some extent in various parts of Northern Russia. In the background there seems to have been the sound shift $* g>d$. There is only one occurrence of a generic that is certainly Finnic: *oja > -uya.

It is possible to speculate whether $-(y)$ er is a Finnic shortened form of the word järvi 'lake' and refers to -aŕl- $\ddot{a}$ '-formants of lakes (MAG44-45) in the headwaters of the River Oyat and in the Belozero region. It is further possible to debate the Estonian shortened form järi or even such toponyms in Finland as Lake In $\mid$ ari in Lapland and Lake $\ddot{A} h t \mid \ddot{a r} i$ in Central Finland. However, one should bear in mind that the toponyms in the Oyat and Belozero region occur in a very narrow area, the Estonian järi is a rare shortened form of the word *järvi and In|ari or Äht|äri (<* Ätsäri) originate from some unknown language. The formant $-(y)$ er occurs in the Upper Volga and Oka area (Map 8) as well.

\subsection{Evidence of ethnonyms}

The ethnonyms of the research area show that the most essential Finno-Ugrian groups were the Chudes and an ethnic group called mer(e)-/ner(e)- (see Section 7). The most important area of chud(e)-toponyms is located in Novgorod and Tver oblasts, in the western part of Moscow oblast and the area of Lake Peipus and the middle course of the River Luga. Mere-, Nere-, and Nar-ethnonyms are located in the Upper Luga and Upper Daugava, in Valday and in the Meryan areas of the chronicles in Central 
Russia (Map 11). In the town of Novgorod there was both a suburb called Nere|vskiy Konets and a street called Chudintsevaya ulitsa. There may be two explanations: 1) the Chudes and Merevas/Nerevas were one tribe with two ethnonyms, the endonym Nere(va) and exonym Chude or 2) the Nerevas and Chudes were two separate linguistic groups which may be reflected e.g. in the word 'lake' as West Chudian *jär(i) and East Chudian (?Nere) *jädralä (see Section 7.2 and Map 11).

The areal distribution of the ethnonyms Chude and Mere/Nere shows that the boundary between them runs mainly alongside the border of modern Tver and Yaroslavl oblasts (Map 11). This shows that the Chudes were not proper Meryans. Also, hydronyms with -emlya and -omlya follow the same line (Map 4). The ancient regional administrative centres Chudskoy stan and Meretskiy stan were also located on this boundary in the vicinity of the town of Uglich, on the left bank of the River Volga (Ryabinin 1997: 168, map 44). Both chud(e)-toponyms and the onomastic similarity show that the original Finno-Ugrian population of Novgorod and Tver oblasts belonged to a large ethnic entity. The eastern boundary followed the western border of the Principality of Vladimir-Suzdal, which in turn seems to have been founded on the basis of the ancient Meryan Land. The areal distribution of chud(e)-toponyms and its northern boundary correspond rather well with the southern boundary of transparently Finnic hydronyms (Map 3) and the boundary of medieval Votes, Ingrians and Vepses as well (Map 1).

\subsection{Lexical evidence}

The vocabulary behind substrate names in Novgorod oblast seems in most cases to be closer to Volgaic Finno-Ugrian languages than Finnic; see above Section 5, formants -dra and -(y)er. ${ }^{33}$ In addition the name of the Lake Kaftino Kaftano oz. (ANO39V4-5, on the boundary of Novgorod and Tver oblasts) in the headwaters of the River Msta being clearly bifurcated seems to originate from a word similar to Erzya Mordvin kavto $\sim$ kafto and Moksha kafta $<$ PFP *kakta (PS 537) 'two'. Close to this is located the Lake Udal' oz. (TVO35B4); cf. Mordvin < udal- 'behind, back'(MW IV 24282431). The lake is not connected with any other water, thus being situated "behind all the other waters". Not faraway from the town of Tver there occur such names of rivers as of the big one In|jukha (TVO188B2) and its smaller tributary Veshka TVO188B3); cf. Mordvin ińe 'big' and veška 'small'. One exception is the word musta (in Mstahydronyms) that occurs in modern languages only in Finnic. However, the word may well have belonged to the lexicon of some language spoken in the Oka and Upper Volga territory. At least the toponyms seem to support this, because Finnic tribes hardly lived in the Lower Klyazma close to Murom or in Moscow oblast and were responsible for the hydronyms with Mst- in Central Russia (see Map 5).

33 In this case Volgaic languages mean Mordvin and Meryan-Muroma, the latter as defined by toponyms. 


\subsection{Hydronyms of Pskov region}

The land between Novgorod and Estonia, i.e. the region of Pskov, seems on the basis of macrotoponyms to have been populated by Slavs since a very early date. A medieval continuation of Finno-Ugrian settlement from South Estonia to Lake Ilmen seems in the light of toponyms almost impossible. The proportion of Balts in the Pskov area does not seem to have been significant. Perhaps in this sense we must return to the Balto-Slavic era. Some hydronyms of Tver oblast, such as Oka [Lovat basin] and $O k \mid c h a$, may possibly be derived from Proto-Balto-Slavic *aka $<$ NW ProtoIndo-European ${ }^{*} h_{2} a k w a h_{2}$ 'water' (Petri Kallio, personal information). As mentioned above, Sedov has come to the same conclusion when defining the northern boundary of Baltic toponyms. He states that the boundary runs on the isthmus located between the rivers Daugava-Dnepr and Lovat-Velikaya south of Novgorod and Pskov (Ryabinin 1997: 4, Fig. 1 according to Sedov).

The great number of Slavic toponyms of the Pskov region support the old hypothesis of its early slavicization presented by many Russian researchers (e.g. Tarakanova 1950; Sedov 1960). This does not mean that the Long Barrow Culture should be connected with Slavs but quite the opposite, as long barrows are found at a very early stage already in the 5th century as far as the Mologa region (Yushkova 2006: 145). It is highly unlikely that the Slavs would have reached the River Mologa so early, which seems to mean that they alone could not be behind the Long Barrow Culture. According to Yushkova (2006: 149), the first small Slavic groups came to the Lake Udomlya (close to the River Mologa) area ca 500-750 AD. Presumably the Long Barrow Culture was multi-ethnic, i.e. Baltic-Slavic-Finno-Ugrian. The Pskov region could be the contact area that brought the earliest Early Middle-Slavic loanwords already ca 300-400 AD through ancient south-eastern Estonians and Novgorodian Chudes into the Finnic speaking area.

A smaller Finnic population has lived in different times in the area of modern Novgorod and Tver oblasts. The dating of their migrations remains obscure. It is well known that Karelian and Ingrian refugees migrated in the 17th century (see Map 3), but supposedly the economical attraction of Novgorod brought a Finnic population from Ingria and Karelia already in earlier times (see the Birchbark Documents in Section 2.2). It seems on the basis of archaeological evidence that the so-called Vesb people (?Veps) came to the Mologa area already in the Viking Age (Makarov 1999: 59-62). It is possible that Livonians also wandered via the River Daugava up to Valday; cf. the ethnonymic hydronyms Libya and Livitsa. In any case, Finnic migrants were not the aboriginal Novgorodian Chudes of the chronicles.

\subsection{Oka-Upper-Volgaic influence}

Finally, I present through five factors a summary of Maps 4, 5, 7, 11 and 12 that shows Oka-Upper-Volgaic influence clearly reaching Novgorod and territory of Lake Ilmen. It is possible to achieve corresponding results by comparing the toponyms with the 


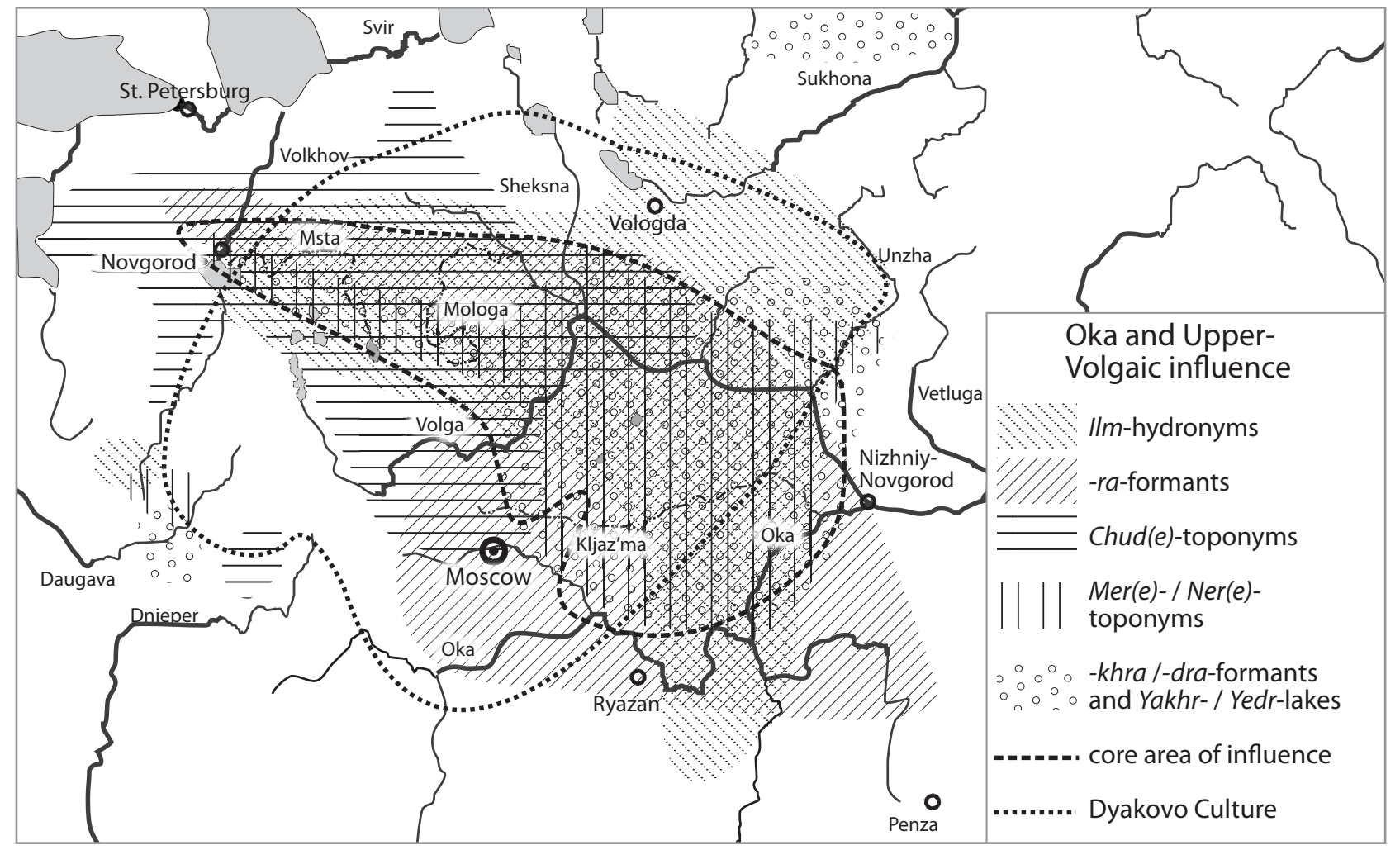

Map I2. IIm hydronyms, Chude and Mere-/Nere- toponyms, ra- and -khra-, -dra- formants and Yakhr-/Yedr-lakes. The core area has been defined by three (3) of five (5) factors influencing together at the same time; see above Maps 5, 6, 8, 10 and II.

distribution of the Dyakovo Culture (Map 12 featuring Patrushev 2000: 90; Makarov 1999: 55; Ryabinin 1997: 161).

Jouni Vaahtera (2009: 95) has considered the origin of the Russian ёканьеdialect to be a Meryan substrate influence. This dialectal area is especially strong in Yaroslavl and Vladimir oblasts and continues westwards sporadically so that the surroundings of Lake Ilmen still belong to the ёканье-area as well. As presented above, it seems that the "Eastern Chudes" were linguistically and culturally (cf. horse-shaped pendants mentioned above) close to the Meryans.

This work is not at all the final word on the present subject. One purpose of this article is to attract a younger generation of scholars to the study of the Finno-Ugrians of the ancient Novgorodian Land. More thorough research of the stems and specifics of hydronyms might reveal much more of the lexicon of the ancient Novgorodian Chudes. It may be fruitful to study microtoponyms as well. This especially concerns the areas where the density of Finno-Ugrian macrotoponyms is high. It might thus be possible to define the latest layer of the toponyms. This means that expeditions should be organized to this area, and it would be easier to distinguish the toponyms named by the relatively late Karelian and Ingrian migrants from the more early names originating from the Novgorodian Chudian language. The question of "West Chudes" and "East Chudes" has not been solved to a satisfactory extent in this work. 


\section{Appendix}

\section{Hydronyms of Leningrad oblast from the map Obzorno-Geograficheskaja karta [LPNP] (N=north, $\mathrm{S}=$ south)}

Avloga V5S, Cheremenskoye oz. Z4S, Cherma Z1S, Choga I8N, Chud|lya K3N, Galmach|ikha I1S, Khabol|ovo oz. D2S, Khepo|yarvi oz. G5S, Il'mas I8N, Izhora ( Inkere) D5S, Kem|ka Ž4S, Kikhtol|ka E2S, Kobo|na I3N, Kopan|skoye oz. D2S, Kost |uya K3N, Kus|ega I5N, Kusi|nka K4N, Lembol|ovskoye oz. V5S, Lemovzha Ž3S, Lipovskoye oz. D2S, Lyamzha I7N, Lyussa Z2S, Lyuta Z2S, Ludo|nka I3S, Luti|nka Ž4S, Lynna I5N, Mar’i|nka K4N, Mga D6S, Nazi|ya I3N, Neva D5S, Nudo|ksa K6N, Obnova Ž3S, Okhta V5S, Olesh|nya K4N, Olo|m|na K4N, Oredezh E4S, Pinega I6N, Pit' I7N, Pyal'itsa; Bol. I8N, Puz|oya I8N, Radil|ovo K3S, Ragoz|inka G5S, Rap|lya L6N, Saba Ž3S, Samro oz. Ž2S, Sapa I6N, Sestra G4S, Sit|nya I3S, Syas' I5N, Sol|ka E2S, Suyda E4S, Suksa I6N, Suma D2S, Shchalo oz. K5N, Shizh|nya I6N, Shomu|ksha I6N, Shug|ozero I7N, Tosna D5S, Tikhvin|ka K7N, Tig|oda L4N, Tumo|ka I7N, Ukhta E3S, Vegotskoye oz. I4N, Vel'ya L4N, Verd|uga Z3S, Vyalye oz. Ž4S, Vl|oya K4N, Voytol|ovka D6S, Voya Ž3S, Volgom $\mid$ ka I5N, Volo|yarvi oz. V5S, Volo|zh|ba K6N, Yanya Z2S, Yashchera Ž4S, Yegl|inka E5S.

\section{Hydronyms of Novgorod oblast from the map ANO}

Andolovka 12G1, Chagoda 13A5, Chagoda 19B5, Chagodoshcha 6-7A8, Chagodskoye oz. 34B2, Chechora 28V2, Cherenka 18B1, Cherenka 17A4, Cherenskoye oz. 17A4, Chichilovka 46B1, Chuchemlya 27V5, Chuchemlya oz. 27V5, Chudovka 24V2, Chudskoye oz. 50B2, Il'men'oz. 34B2, Il'men' 19V5, Ingor' 14B4, Izhina 30B4, Kadvisha 27V5, Kaftino 39V5, Kalenoye oz. 48A3, Kaleshev 30V2, Kaleshevka 29V5, Karkomlya 40B3, Kastenka 12B1, Kashirka 24A3, Kat' 30B3, Keza 41V5, Kezadra 41V3, Kemka 39V4, Kerest' 14V2, Khachin 54V2, Khadritsa 26V4, Khuba 23V6, Khubka 23V5, Kiba 32A2, Kirva 30B2, Kirishkoye oz. 14A2, Kit'ma 29V5, Kobozha 28A3, Kobozha 30A2, Kocha 54G1, Koyegoshcha 38A3, Kolba 35V5, Kolodezhskoye oz. 34A2, Kolomenka 31V1, Kolomenka 48A3, Koloshka 32V2, Komel' 25B3, Koregoshch oz. 54V1, Korkomlya 30A3, Korpovka 34V2, Korpovka 45V5, Kostygovka 46V1, Kostyzhenskoye oz. 30B2, Kotyl' 30B2, Kova 47V5, Kreksha 34V2, Kudra 47B3, Lamerskoye oz. 36B3, Lib'ya 47B4, Limandrovka 39A5, Lipyarvi oz. 18B3, Mda 25A3, Mdo oz. 26A2, Mezga 30A4, Melegusha 17A4, Meneksha 14V2, Merevskoye oz. 20B1, Merlozhinskaya 55A5, Mologa 30B3, Mologzha 25V5, Molonitsa 41B5, Msta 34A2, Mstizhskoye oz. 46V2, Mshaga 32B3, Neverka 46B3, Nevery oz. 46B3, Nezdrinskoye oz. 25G3, Nemega oz. 48B2, Neretskoye oz. 37V4, Nertsa 37A3, Niga oz. 27B6, Nil'skoye oz. 34A3, Nudynya 14A3, Nurdysha 33B5, Oka 55B3, Okzovka 15G5, Oksochka 24V3, Omash 29B5, Omsha oz. 17V5, Omsha oz. 27V5, Omsha 17V5, Oredezh 20B1, Oskuya 14B2, Oskuyskoye oz. 14B3, Pyardomlya 17A6, Ponyr' 18B1, Priksha 26A2, Rabezha 
47V5, Ravan' 13B5, Ragusha 17B5, Radoga 29B4, Radol' 40A1, Radol'skoye oz. 40B2, Radokha 14B2, Raduga 31G3, Raduga 37A3, Radulya oz. 26A2, Raplya 16A2, Rdeyskoye oz. 50B2, Redekha 40B1, Redya 34V3, Redrovo oz. 28B3, Retno oz. 21A4, Retomlya 17V5, Rotno oz. 17V5, Rotnoye oz. 26V2, Ryaplya 16B1, Ryasno oz. 54V3, Saba 20G2, Sabro oz. 54G1, Sabrovka 54G1, Sapina 17B4, Saragozha 41B5, Seliger oz. 54V2, Seregizhna 23V5, Seremno oz. 54B3, Seremo oz. 54V2, Serezha 55A3, Sermenok oz. 54V2, Sig oz. 54G2, Sivel'ba 38A3, Siverik oz. 17V4, Siverka 23V5, Sizovka 52V2, Syas' 17A4, Smerdomka 19V4, Sormal' oz. 26A3, Soroga 54V3, Stabenka 53A3, Sudomlya 18B1, Suglinka 19A3, Suytsa; Bol. 12B1, Sun'ya 12B2, Surovskoye oz. 12B1, Suvatel'12A2, Shaboderka 40B1, Shabodro oz. 40B1, Shadomlya 28G2, Shalimovka 26V2, Shambolovka 44V3, Shar'ya 14B3, Shedomets oz. 38B3, Shegrinka 26G2, Shelon' 33B4, Sheregodra oz. 27B4, Sheshno oz. 38B2, Shigolka 19B4, Shildushka 25B4, Shuya 16V3, Shuyarvi-Shu, bol. 18B3, Shulakovka 51G5, Shul'ga 50V3, Taborka 18A3, Tagran'oz. 48A1, Tigoda oz. 12G2, Tigoda 14A2, Tikhomandritsa 40V3, Tsevlo oz. 49V2, Tsozhenka 55A4, Tuder; Bol. 51V4, Tuder; Mal. 50V3, Tuleblya 34V2, Tushemel'ka 19B3, Tushemel'skoye oz. 19B4, Uchenskiy 45B4, Uchonka 34V2, Udal'oz. 39V4, Udina 27B5, Udomlya oz. 40G3, Unomerka 32A2, Ushenka 42V3, Ushkovo oz. 26A2, Uzminka oz. 18B2, Uzha oz. 26B3, Vagan oz. 16V3, Valdayka 38V2, Valdayskoye oz. 37G5, Veksha 33B3, Vergot' 34V3, Veregzha 27B4, Verkasenka 34B3, Veronda 33A5, Veryazha 33A5, Vitsa 50G2, Virovno oz. 23A4, Viska43V4, Vittsa 36A2, Vishera22V2, Vishera; Bol. 14G4, Vishera; Mal. 23A6, Visherka; Bol. 23B5, Vyalets oz. 26B4, Vyaloye oz. 24V3, Vyazhitskoye oz. 21V5, Vozhanskoye oz. 19B4, Volga 53B4, Voldomitsa 30G1, Volzhanka 40V1, Volma 36A1, Volozha 34V4, Volozhba 17A5, Volkhov 22V2, Vorozhba 41G4, Yaimlya 36B2, Yashchera 6-7A1, Yavon' 46V1, Yederka 48A3, Yedrovo oz. 48A2, Yeglinka 12B2, Yeglinka 37V4, Yeglino oz. 37V4, Yelimna 14B4, Yemetskoye oz. 27A5, Yemenets 28G2, Yeresha 21B5, Yurinka 26G3. 


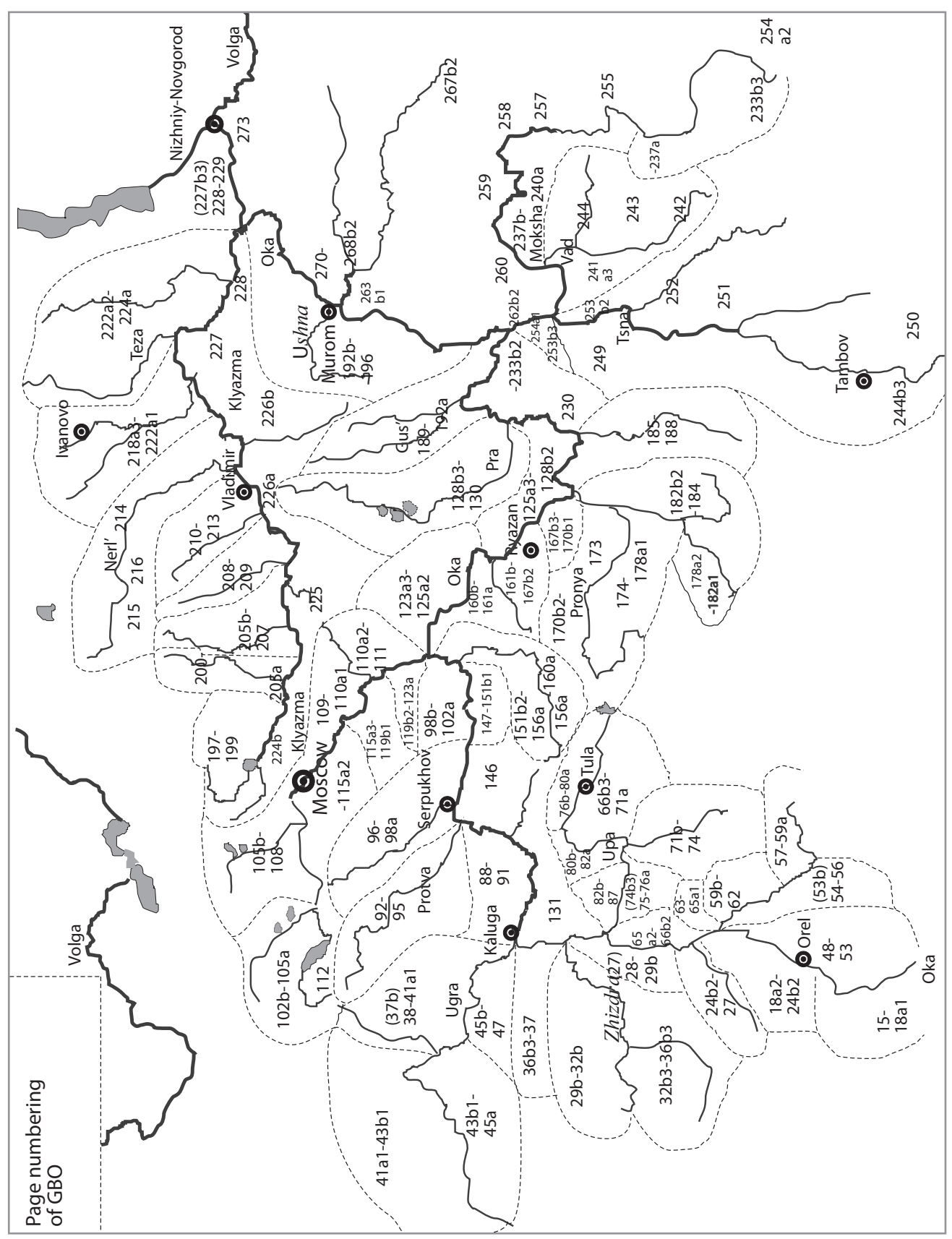

Map 13. Location of hydronyms according to the page numbers of GBO. 


\section{References}

\section{Maps}

$\mathrm{AIO}=$ Атлас - Ивановская область (1:200 000) 2007: Нижный Новгород: ФГУП Верхневолжское Аэрогеодезическое Предприятие.

AJO = Атлас Ярославской области (1:100 000) 2002: Москва: Роскартография.

AKO = Атлас Костромской области (1:100 000) 2009: Москва: Роскартография.

$\mathrm{AMO}=$ Атлас Московской области (1:100 000) 2007: Москва: Роскартография.

ANO = Атлас-Новгородская область (1:200 000) 2006: Новгород: ФГУП Новгородское Аэрогеодезическое Предприятие.

ARK = Атлас Республика Коми (1:200 000) 2006: Санкт Петербург: ФГУП Аэрогеодезия.

$\mathrm{ARO}=$ Атлас Рязанской области (1:100 000) 2006: Москва: Роскартография.

$\mathrm{ASO}=$ Атлас Смоленской области (1:100 000) 2008: Москва: Роскартография.

ATO = Атлас Тверской области (1:100 000) 2005: Москва: Роскартография.

AUR = Атлас - Удмуртская Республика (1:200 000) 2007: Екатеринбург: Министерство транспорта Российского Федерации. Федеральное агенство геодезии и картографии. ФГУП «Уралогеодезия».

AVLO = Атлас Владимирской области (1: 100 000) 2008: Москва: Роскартография.

$\mathrm{AVO}=$ Атлас - Вологодская область (1:200 000) 2008: Санкт Петербург: ФГУП Аэрогеодезия.

GT2000 tiekartasto (1:200 000) 2000: Helsinki: Karttakeskus.

GUGK: Arkhangel = Архангель - Главное управление геодезии и картографии (1:100 000) 1990: Ленинград: ГУГК СССР.

GUGK: Kotlas = Котлас - Главное управление геодезии и картографии (1:100 000) 1990: Ленинград: ГУГК СССР.

GUGK: Onega = Онега - Главное управление геодезии и картографии (1:500 000) 1990: Ленинград: ГУГК СССР.

LPNP = Обзорно-Географическая карта - Ленинград-Псков-Новгород-Петрозаводск (1:400 000) 1990: Ленинград: ВТУ ГШ.

RAV = Регионалный Атлас. Вологодская область (1:200 000) 2001: Москва: ВТУ ГШ.

TKКО = Топографическая карта - Костромская область (1:200 000) 1997: Москва: ВТУ ГШ.

TKRK = Топографическая карта - Республика Карелия (1:200 000) 1997: Москва: ВТУ ГШ.

\section{Literature}

Ageyeva = Агеева, Р. А. 1980: Гидронимия балтского происхождения на территории Псковских и Новгородских земель. - Этнографические и лингвистические аспекты этнической истории балтских народов. Рига. 147-152.

Ahlqvist = Альквист, Арья 1992: Наблюдения над финно-угорским субстратом в топонимии Ярославского края на материале гидронимических формантов - $(V) z a$ и (V)нга, (V)ньга, (V)нда. - Studia Slavica Finlandensia. Tomus IX. Helsinki. 1-50.

Ahlqvist = Альквист, Арья 1997: Мерянская проблема на фоне многослойности топонимии. - Вопросы Языкознания 1997: 6. Москва. 22-35.

Ahlqvist, Arja 1998a: Merjalaiset - Suurten järvien kansaa. - Virittäjä 102: 1: 24-55. 
Ahlqvist = Альквист, Арья 1998b: Субстратная лексика финно-угорского происхождения в говорах Ярославско-Костромского Повольжя. - Studia Slavica Finlandensia. Jyrki Papinniemi, Jouko Lindstedt, Pekka Pesonen (eds). Tomus XV. Helsinki.

Ahlqvist, Arja 1999: Ihmisiähän ne merjalaisetkin olivat... - Virittäjä 103:4: 624-637.

Ahlqvist = Альквист, Арья 2001: Субстратная топонимия Ярославского Поволжья. А. С. Герд \& Г. С. Лебедев (eds), Очерки исторической географии. Северо-запад России. Славяне и финны. С.-Петербург: Издательство С.-Петербургского университета. 436-467.

Ahlqvist = Альквист, Арья 2004: О следах финно-угорской культуры на Ярославской земле (на основе данных топонимии). - Роль творческой личности в развитии культуры провинциального города. Ярославл: Алмазовские чтения. 9-18.

Ahlqvist, Arja 2006: Ancient Lakes in the Former Finno-Ugrian Territories of Central Russia: An experimental Onomastic-Palaeological Study. - The Slavicization of the Russian North. - Juhani Nuorluoto (ed.). Slavica Helsingiensia 27. Helsinki: Department of Slavonic and Baltic Languages and Literatures at Helsinki University. 11-49.

Aikio, Ante 2004: An essay on substrate studies and the origin of Saami. - Irma Hyvärinen, Petri Kallio \& Jarmo Korhonen (eds), Etymologie, Entlehnungen und Entwicklungen. Festschrift für Jorma Koivulehto zum 70. Geburtstag. Mémoires de la Société Néophilologique de Helsinki 63. Helsinki: Société Néophilologique. 5-34.

Aikio, Ante 2007: The Study of Saami substrate Toponyms in Finland. - Onomastica Uralica 4. Helsinki: Debrecen. 157-197.

Ainiala, Terhi \& Saarelma, Minna \& Sjöblom, Paula 2008: Nimistöntutkimuksen perusteet. Tietolipas 221. Helsinki: Suomalaisen Kirjallisuuden Seura.

Ariste, Paul 1962: Mõni sõna leivudest. - Etnograafia Muuseumi Aastaraamat 18. Tallinn. 266-275.

Bartens, Raija 1999: Mordvalaiskielten rakenne ja kehitys. Suomalais-Ugrilaisen Seuran Toimituksia 232. Helsinki: Suomalais-Ugrilainen Seura.

Bubrikh = Бубрих, Д. В. 1947: Происхождение Карельского народа. Повесть о союзнике и другие Русского народа на севере. Петрозаводск: Государственное издательство Карело-Финской ССР.

Carpelan, Christian \& Parpola, Asko 2001: Emergence, contacts and dispersal of Proto-IndoEuropean, Proto-Uralic and Proto-Aryan in archaeological perspective. - Early contacts between Uralic and Indo-European: Linguistic and Archaeological considerations. Suomalais-Ugrilaisen Seuran Toimituksia 242. Helsinki: Suomalais-Ugrilainen Seura. 55-150.

Carpelan, Christian 2006: On Archaeological Aspects of Uralic, Finno-Ugric and Finnic Societies before AD 800. - Juhani Nuorluoto (ed.), The Slavicization of the Russian North. Slavica Helsingensia 27. Helsinki: Department of Slavonic and Baltic Languages and Literatures at Helsinki University. 78-92

Chernyagin = Чернягин, Н. Н. 1941: Длинние курганы и сопки. - Материалы и исследования по археологии СССР 6. 93-148.

Cross, S. H. \& Sherbowitz-Wetzor, O. P. 1953: The Russian Primary Chronicle. Laurentian text. Cambridge, Mass.

$\mathrm{Dal}=$ Даль, Владимир 1880-82: Тольковый словарь живого великорусского языка. I-IV. Moskva.

EEW = Julius Mägiste 2000: Estnisches Etymologisches Wörterbuch II. Hernes - Kamm. Finnisch-Ugrische Gesellschaft.

ESRJ = Фасмер, Макс 2003: Этимологический словарь русского языка I-IV. Москва: Астрель.Аст. 
Goryunova $=$ Горюнова, Е. И. 1967: Меря и Марий. - Происхождение марийского народа. Йошкар Ола.

GBO = Смолицкая, Г. П. 1976: Гидронимия бассейна Оки. Москва: Издательство Наука. Gote $=$ Готье, Ю. В. 1930: Железный век в восточной Европе. Москва-Ленинград.

Grünthal, Riho 1997: Livvistä liiviin: Itämerensuomalaiset etnonyymit. Castrenianumin toimitteita 51. Helsinki: Helsingin yliopisto - Suomalais-Ugrilainen Seura.

Häkkinen, Jaakko 2010: Jatkuvuusperustelut ja saamelaisen kielen leviäminen (osa 2). Muinaistutkija 2/2010. Helsinki: Suomen Arkeologinen Seura. 51-64.

Isakov = Исаков, В. 3. 1985: Озеро Селигер. Москва: Профиздат.

Itkonen, Erkki 1961: Suomalais-ugrilaisen kielen- ja historiantutkimuksen alalta. - Tietolipas 20. Helsinki.

Jaakkola, Jalmari 1935: Suomen varhaishistoria. - Suomen historia 2. Porvoo-Helsinki.

De Jode, Cornelius \& Jenkinson, Anthonius 1571: Theatrvm orbis terrarum, Russice, Moscovice et Tartarice Descriptio. Amsterdam-London.

Kallio, Petri 2006: On the Earliest Slavic Loanwords in Finnic. - Juhani Nuorluoto (ed.), The Slavicization of the Russian North. Slavica Helsingesia 27. Helsinki: Department of Slavonic and Baltic Languages and Literatures at Helsinki University. 154-166.

Kallio, Petri 2007: Kantasuomen konsonanttihistoriaa. - Jussi Ylikoski ja Ante Aikio (eds), Sámit, sánit, sátnehámit. Riepmočála Pekka Sammallahtii miessemánu 21. beaivve 2007. Suomalais-Ugrilaisen Seuran Toimituksia 253. Helsinki: Suomalais-Ugrilainen Seura. 229-249.

Kirkinen, Heikki 1994: Karjalan historia, juurista Uuden kaupungin rauhaan. - Karjalan kansan historia. Porvoo: WSOY. 13-171.

Kiviniemi, Eero 1980: Nimistö Suomen esihistorian tutkimuksen aineistona. - Virittäjä 86: 4: 319-338.

Kiviniemi, Eero 1990: Perustietoa paikannimistä. Helsinki: Suomalaisen Kirjallisuuden Seura.

KKM = Bubrih, D. V. - Beljakov A. A. - Punžina, A. V. 1997: Karjalan kielen murrekartasto. Helsinki: Venäjän tiedeakatemian Karjalan tiedekeskuksen kielen, kirjallisuuden ja historian instituutti. Kotimaisten kielten tutkimuskeskus. Suomalais-Ugrilainen Seura.

KKS = Karjalan kielen sanakirja I-VI 1968-2005. Pertti Virtaranta (I-III), Raija Koponen (IV-VI) (eds). Lexica Societatis Fenno-Ugricae XVI. Kotimaisten kielten tutkimuskeskuksen julkaisuja 25. Helsinki: Suomalais-Ugrilainen Seura - Kotimaisten kielten tutkimuskeskus.

Koivisto, Andreas 2006: Trade Routes and their Significance in the Christianization of Karelia. - Juhani Nuorluoto (ed.), The Slavicization of the Russian North. Slavica Helsingesia 27. Helsinki: Department of Slavonic and Baltic Languages and Literatures at Helsinki University. 167-178.

Koivulehto, Jorma 2006: Wie alt sind die Kontakte zwischen Finnisch-Ugrisch und BaltoSlavisch? - Juhani Nuorluoto (ed.), The Slavicization of the Russian North. Slavica Helsingiensia 27. Helsinki: Department of Slavonic and Baltic Languages and Literatures at Helsinki University. 179-196.

Korotkevich = Короткевич, Б. С. 2001: Днепродвинцы на севере. О начале раннего железного века в Приильменье. - Д. А. Мачинский \& А. А. Селин (eds), Миграчии и оседлость от Дуная до Ладоги в I тысячлетии христианской эры. Санкт Петербург: Староладожский историко-архитектурный и археологический музейзаповедник. 28-31. 
Kriiska, Aivar \& Tvauri, Andres 2007: Viron esihistoria. Hannu Oittinen \& Andres Tvauri (suom.). Helsinki: Suomalaisen Kirjallisuuden Seura.

Krysko = Крысько, В. Б. 2006: Еще раз об Имоволожи. - Juhani Nuorluoto (ed.), The Slavicization of the Russian North. Slavica Helsingiesia 27. Helsinki. 222-233.

Kuleshov = Кулешов, В. С. 2001: К вопросу о происхождении названия «Ладога». Д. А. Мачинский \& А. А. Селин (eds). Миграции и оседлость от Дуная до Ладоги в I тысячлетии христианской эры. Санкт Петербург: Староладожский историко архитектурный и археологический музей-заповедник. 73-76.

Laul, S. 1973: Zur Frage über die Hügelgräber in Südostestland. - Suomen Muinaismuistoyhdistyksen Aikakauskirja 75. Helsinki. 95-102.

LAŽ = Peteraitis, Vilius 1985: Lietuviškai-Angliškas Žodynas. Lithuanian-English Dictionary. Chigago: Lietuviškos Knygos Klubas.

Lehtiranta, Juhani 2001: Yhteissaamelainen sanasto. Suomalais-Ugrilaisen Seuran Toimituksia 200. Helsinki: Suomalais-Ugrilainen Seura.

Lihatshov = Lihatšov, D. S. 1994: Nestorin kronikka [Повесть временных лет]. МarjaLeena Jaakkola (suom.). Porvoo-Helsinki-Juva: WSOY.

Lind, Johan 2006: Problems of Ethnicity in the Interpretation of Written Sources on Early Rus'. - Juhani Nuorluoto (ed.), The Slavicization of the Russian North. Slavica Helsingiesia 27. Helsinki: Department of Slavonic and Baltic Languages and Literatures at Helsinki University. 246-258.

Lyapushkin = Ляпушкин, И. И. 1966: Археологические памятники славян лесной зону Восточной Европы на кануне образования древнерусского государства (VIII-IX вв.). - Культура древней Руси. Москва. 127-136.

Lyapushkin = Ляпушкин, И. И. 1968: Славяне Восточной Европы накануне образования древнерусского государства. - Материальы и исследования по археологии СССР 152. Ленинград.

Lytkin \& Gulyayev = Лыткин, В. И. \& Гуляев, Е. С. 1999: Краткий этимологический словарь коми языка. Сыктывкар: Коми книжное издательство.

Machinskiy = Мачинский, Д. А. 1986: Этносоциалные и этнокультурные процессы в Северной Руси (период зарождения древнерусской народности). - Русский Север. Ленинград. 3-29.

Machinskiy = Мачинский, Д. А. 1990: О роли финноязычного населения бассейнов Волхова и Великой в сложении этносоциума «Рус» (VIII-XI вв.). - Современное финноугроведение. Опыт и проблемы. Ленинград. 110-120.

MAG = Муллонен, И. И. \& Азарова, И. В. \& Герд, И. В. 1997: Словарь гидронимов юговосточного Приладожья бассейн реки Свирь. Санкт-Петербург: Издательство Санкт Петербургского университета.

Makarov = Макаров, Н. А. 1999: Финны и славяне на Белом озере: Проблемы преемственности систем расселения и культурная ландшафта. - Новые исследования по средневековой археологии Поволжья и Приуралья. Ижевск-Глазов: Российская академия наук уральское отделение - Удмуртский институт истории, языка и литературы - Правительство Удмуртской Республики - Российский гуманитарный научный фонд - Администрация города Глазова - Историко-культурный музей-заповедник «Иднакар». 52-64.

Makarov, N. A. 2006: Cultural Identity of the Russian North Settlers in the 10th-13th Centuries: Archaeological Evidence and Written Sources. - Juhani Nuorluoto (ed.), The Slavicization of the Russian North. Slavica Helsingensia 27. Helsinki: Department of Slavonic and Baltic Languages and Literatures at Helsinki University. 259-281. 
Mallory, J. P. \& Adams D. Q. (eds) 1997: Encyclopedia of Indo-European Culture. London: Fitzroy Dearborn Publishers.

Matveyev = Матвеев, А. К. 2001, 2004, 2007: Субстратная топонимия Русского Севера I-III. Екатеринбург: Издательство Уральского университета.

Matveyev = Матвеев, А. К. 2006: Ономатология. Москва: Российская академия, отделение историко-филологических наук. «Наук».

Mercator, Gerard 1595: Atlas sive cosmographica...Russia cum confinijs. Amsterdam.

MFM = Moisio, Arto 1992: Marilais-Suomalainen sanakirja - Marla-Finla muter. Turku: Turun yliopiston suomalaisen ja yleisen kielitieteen julkaisuja.

Mikhaylova = Михайлова, Е. Р. 2001: К обоснованию нижней даты псковских длинных курганов. Приильменье. - Д. А. Мачинский \& А. А. Селин (eds), Миграции и оседлость от Дуная до Ладоги в I тысячлетии христианской эры. Санкт Петербург: Староладожский историко-архитектурный и археологический музей-заповедник. 35-46.

Moora, Harri 1956: Eesti rahva ja naaberrahvaste kujunemisest arheoloogia andmeil. Eesti rahva etnilisest ajaloost. Tallinn. 41-119.

Mullonen = Муллонен, И. И. 2002: Топонимия Присвирья. Проблемы этноязыкого контактирования. Петрозаводск: Российская академия наук, карельский научный центр: Институт языка, литературы и истории.

MGT 1970 = Местные географические термины. Вопросы географии, Сборник восемьдесят первый. Научние сборники московская филиала географического общества СССР под руководством Н. Н. Баранского. Москва: Издательство «Мысл».

MW = Paasonen, H. 1990-99: Mordvinisches Wörterbuch. Lexica Societatis Fenno-Ugricae XXIII, 1-6. Zusammengestellt von Kaino Heikkilä. Helsinki: Suomalais-Ugrilainen Seura.

Mägiste, Julius 1950: Tšuudien kansallisuusnimen alkuperän ongelma ja suomen suudin, vir. suue 'kiila'. - Virittäjä 54: 74-79.

$\mathrm{NA}=$ Kotimaisten kielten tutkimuskeskuksen nimiarkisto. Helsinki.

Nissilä, Viljo 1975: Suomen Karjalan nimistö. Joensuu: Karjalaisen Kulttuurin Edistämissäätiön julkaisuja.

Nuorluoto, Juhani 2006: Is there a Sound Change of " $e>o$ " in Russian? - Juhani Nuorluoto (ed.), The Slavicization of the Russian North. Slavica Helsingensia 27. Helsinki: Department of Slavonic and Baltic Languages and Literatures at Helsinki University. 293-308.

Nuorluoto, Juhani 2007: The interchangeability of the Graphemes $<_{\mathbf{0}}>_{\text {and }}<_{\mathbf{b}}>_{\text {in Old Rus- }}$ sian Birchbark Documents: A Graphical Effect or a Reflection of Sound Change in Progress? - Topics on the ethnic, linguistic and cultural making of the Russian North. Slavica Helsingensia 32. Helsinki: Department of Slavonic and Baltic Languages and Literatures at the University Helsinki. 176-195.

Nuutinen, O 1989: Järvi - balttilainen laina. - Virittäjä 93: 497-503.

Ortelius, Abraham 1595: Additamentvm quintum, Thatri orbis terrarvm, Evropam, sive celticam veterem. Antverpen.

Pajula, Marja \& Vanhanena, Iveta \& Samcova, Jelena 1997: Latviešu-Somu, Somu-Latviěsu Vārdnīca. Raita Saleniece (ed.). Rīgā: Norden.

Patrushev, Valery 2000: The Early History of the Finno-Ugric Peoples of European Russia. Oulu: Societas Historiae Fenno-Ugricae.

Pitkänen, Ritva Liisa 1985: Turunmaan saariston suomalainen lainanimistö. Suomalaisen Kirjallisuuden Seuran Toimituksia 418. Helsinki: Suomalaisen Kirjallisuuden Seura. 
Popov = Попов, А. И. 1947: Из истории финно-угорских народностей СССР. Ленинград. Popov = Попов, А. И. 1981: Следы времен минувсих: Из истории географических названий Ленинградской, Псковской и Новгородской областей. Ленинград.

PSRL 1965 = Полное собрание русских летописей 9-12. Москва.

Rahkonen, Pauli 2009: The Linguistic Background of Meshchera Tribe and Principal Areas of Settlement. - Finnisch-Ugrische Forschungen 60: 162-202.

Rozenfeldt $=$ Розенфельдт, Р. Л. 1974: Керамика дьяковской культуры. - Дьяковская культура. Москва.

Ryabinin = Рябинин, Е. А. 1981: Зооморфные украшения Древней Руси X-XIV вв. Ленинград.

Ryabinin = Рябинин, Е. А. 1997: Финно-угорские племена в составе древней Руси. Санкт-Петербург: Издательство Санкт Петербургского университа.

Räisänen, Alpo 2003: Nimet mieltä kiehtovat: etymologista nimistöntutkimusta. Suomalaisen Kirjallisuuden Seuran Toimituksia 936. Helsinki: Suomalaisen Kirjallisuuden Seura.

Saarikivi, Janne 2004: Über die saamischen Substratennamen des Nordrusslands und Finnlands. - Finnisch-Ugrische Forschungen 58: 162-234.

Saarikivi, Janne 2006a: Introduction. - Substrata Uralica. Studies on Finno-Ugric Substrate in Northern Russian Dialects. 7-50.

Saarikivi, Janne 2006b: On the Uralic Substrate Toponymy of Arkhangelsk Region: Problems of Research Methodology and Ethnohistorical Interpretation. - Onomastica Uralica 4. Debrecen. 1-64.

Saarikivi, Janne 2007: Finnic Personal Names on Novgorod Birch Bark Documents. - The Slavicization of the Russian North. - Juhani Nuorluoto (ed.). Slavica Helsingensia 32. Helsinki: Department of Slavonic and Baltic Languages and Literatures at Helsinki University. 196-246.

Saarikivi, Janne \& Grünthal, Riho 2005: Itämerensuomalaisten kielten uralilainen tausta. - Johanna Vaattovaara, Toni Suutari, Hanna Lappalainen, Riho Grünthal (eds). Muuttuva muoto: Kirjoituksia Tapani Lehtisen 60-vuotispäivän kunniaksi. Kieli 16. Helsinki: Helsingin yliopiston suomen kielen laitos. 111-146.

Salmons, Joe 1992: Northwest Indo-European vocabulary and substrate phonology. - Roger Pearson (ed.), Perspectives on Indo-European language, culture and religion: studies in honor of Edgar C. Polomé. Vol. 2. Journal of Indo-European Studies, Monograph Series 9: 265-279.

Sammallahti, Pekka 1988: Historical phonology of Uralic languages. With special reference to Samoyed, Ugric and Permic. - Denis Sinor (ed.), Uralic Languages. Description, history and foreign influences. Leiden - New York - København - Köln.: E. J. Brill. 478-554.

Sammallahti, Pekka 1989: Sámi-Suoma sátnegirji. Saamelais-suomalainen sanakirja. Ohcejohka: Jorgaleaddji Oy.

Sammallahti, Pekka \& Morottaja, Matti 1993: Säämi-Suomâ sänikirje. Inarinsaamelais-suomalainen sanakirja. Ohcejohka: Girjegiisá Oy.

Sammallahti, Pekka 1999: Saamen kielen ja saamelaisten alkuperästä. - Pohjan poluilla. Suomalaisten juuret nykytutkimuksen mukaan. - Paul Fogelberg (ed.). Bidrag till kännedom av Finlands natur och folk 153. Helsinki: Finska Vetenskaps-Societeten. Suomen Tiedeseura. 70-90.

Sedov = Седов, В. В. 1960: Кривичи. - Советская археология 1. Москва. 47-62.

Sedov = Седов, В. В. 1979: Этнический состав населения Новгородской земли - Финноугры и славяне. Ленинград. 74-80. 
Sedova = Седова, М. В. 1981: Ювелирные изделия Древного Новгорода (X-XV вв.). Москва.

$\mathrm{SMJ}=$ Словарь марийского языка 1-10 1990-2005: Йошкар-Ола: Марийский научноисследовательский институт.

Sokolova = Соколова, М. А. 1962: Очерки по исторической грамматике русского языка. Москва.

Spitsyn = Спицын, А. А. 1903: Удлиненные и длинные русские курганы. - Записки отделения русской и славянской археологии. Том V, 1. Санкт-Петербург. 196-202.

SP = Suomen paikannimikirja 2007: - Sirkka Paikkala (ed.). Jyväskylä: Karttakeskus, Kotimaisten kielten tutkimuskeskus.

SSA = Suomen sanojen alkuperä I-III. 1992-2000. Itkonen, Erkki \& Kulonen, Ulla-Maija (eds). Suomalaisen Kirjallisuuden Seuran Toimituksia 556. Kotimaisten kielten tutkimuskeskuksen julkaisuja 62. Helsinki: Kotimaisten kielten tutkimuskeskus - Suomalaisen Kirjallisuuden Seura.

Shilov = Шилов, А. Л. 2001: О языковой принадлежности некоторых топонимов древней новгородской земли. - Топонимия и диалектная лексика новгородской земли. Великий Новгород. 23-26.

Tarakanova = C. А. 1950: О происхождение и временни возниковения Пскова. - Kpamкие сообщенния ИИМК XXXV. Москва-Ленинград. 18-29.

Tkachenko = Ткаченко, О. В. 1985: Мерянский язык. Киев: АН Украйнской ССР. Наукова думка.

Tkachenko = Ткаченко, О. В. 2007: Исследования по мерянскому языку. Кострома.

Tretyakov = Третьяков, П. Н. 1953: Восточнославянские племена. Москва.

Tretyakov = Третьяков, П. Н. 1966: Финно-угры, балты и славяне на Днепре и Волге. Москва-Ленинград.

Tunkelo, E. A. 1933: Eräs kuollut denominaalijohdin. - Virittäjä 37: 9.

Tvauri, Andres 2007: Migrants or Natives? The Research History of Long Barrows in Russia and Estonia in the 5th-10th Centuries. - Topics on the ethnic, linguistic and cultural making of the Russian North. Slavica Helsingensia 32. Helsinki: Department of Slavonic and Baltic Languages and Literatures at Helsinki University. 247-285.

UEW = Redej, Karoly (ed.) 1986-91: Uralisches Etymologisches Wörterbuch. Budapest.

Uino, Pirjo 1997: Ancient Karelia. Archaeological Studies. Suomen muinaismuistoyhdistyksen Aikakauskirja 104. Helsinki.

Uino, Pirjo 2006: The Background of the Early Medieval Finnic Population in the Region of the Volkhov River: Archaeological Aspects. - Juhani Nuorluoto (ed.), The Slavicization of the Russian North. Slavica Helsingensia 27. Helsinki: Department of Slavonic and Baltic Languages and Literatures at Helsinki University. 355-373.

Vaahtera, Jouni 2009: Эволюция систему гласных фонем в некоторых русских говорах Вологодской области. Slavica Helsingensia 37. Helsinki: Department of Slavonic and Baltic Languages and Literatures at Helsinki University.

Vasilyev = Васильев, В. Л. 2001: Метонимическое калькирование архайских гидронимов в Приильменье. - Топонимия и диалектная лексика новгородской земли. Велики Новгород: Министерство образования Российской Федерации. Новгородский государственный университет имени Ярослава Мудрого. 6-13.

Vasilyev = Васильев, В. Л. 2005: Архаическая топонимия новгородской земли. Велики Новгород: Новгородский Межрегиональный Институт Общественных Наук.

Veselovskiy = Веселовский, С. Б. 1974: Ономастикон. Древнерусские имена, провища и фамилии. Москва. 
WRG = Vasmer, Max 1961-69: Wörterbuch der Russischen gewässernamen I-V. Berlin.

Zaliznyak = Зализняк, А. А. 2004: Древненовгородский диалект. Москва: Языки славянской культуры.

Yemifimova = Емифимова, Ю. 2001: Особенности формирования вещевого комплекса памятников северной Белоруссии и южной Псковщину в раннем железном веке. Д. А. Мачинский \& А. А. Селин (eds), Миграции и оседлость от Дуная до Ладоги в I тысячлетии христианской эры. Санкт Петербург: Староладожский историкоархитектурный и археологический музей-заповедник. 25-27.

Yushkova, M. A. 2006: North-Western Russia before its Settling by Slavs (8th Century $\mathrm{BC}-8$ th Century AD). Juhani Nuorluoto (ed.), The slavicization of the Russian North. Slavica Helsingiensia 27. Helsinki: Department of Slavonic and Baltic Languages and Literatures at Helsinki University. 140-153.

Pauli Rahkonen <pauli.rahkonen@gmail.com> 